\title{
Inside out : on stereotype awareness, childhood trauma and stigma in psychosis
}

\author{
Citation for published version (APA):
}

van Zelst, C. J. A. M. (2014). Inside out : on stereotype awareness, childhood trauma and stigma in psychosis. [Doctoral Thesis, Maastricht University]. Maastricht University. https://doi.org/10.26481/dis.20141202cz

Document status and date:

Published: 01/01/2014

DOI:

$10.26481 /$ dis.20141202cz

Document Version:

Publisher's PDF, also known as Version of record

\section{Please check the document version of this publication:}

- A submitted manuscript is the version of the article upon submission and before peer-review. There can be important differences between the submitted version and the official published version of record. People interested in the research are advised to contact the author for the final version of the publication, or visit the DOI to the publisher's website.

- The final author version and the galley proof are versions of the publication after peer review.

- The final published version features the final layout of the paper including the volume, issue and page numbers.

Link to publication

\footnotetext{
General rights rights.

- You may freely distribute the URL identifying the publication in the public portal. please follow below link for the End User Agreement:

www.umlib.nl/taverne-license

Take down policy

If you believe that this document breaches copyright please contact us at:

repository@maastrichtuniversity.nl

providing details and we will investigate your claim.
}

Copyright and moral rights for the publications made accessible in the public portal are retained by the authors and/or other copyright owners and it is a condition of accessing publications that users recognise and abide by the legal requirements associated with these

- Users may download and print one copy of any publication from the public portal for the purpose of private study or research.

- You may not further distribute the material or use it for any profit-making activity or commercial gain

If the publication is distributed under the terms of Article $25 \mathrm{fa}$ of the Dutch Copyright Act, indicated by the "Taverne" license above, 


\section{Inside Out}

On stereotype awareness, childhood trauma and stigma in psychosis 
ISBN: 978-90-5335-955-6

Printing: Ridderprint BV, the Netherlands

Cover: Ridderprint BV, the Netherlands

Photo Cover: Nienke van Dijk

C 2014 | C.J.A.M. van Zelst | Maastricht | The Netherlands

All rights reserved. No part of this publication may be reproduced, stored in a retrieval system, or transmitted, in any form or by any means, mechanically, electronically, by photocopy, by recording, or otherwise, without prior written permission from the proprietor. 


\section{Inside out}

\section{On stereotype awareness, childhood trauma and stigma in psychosis}

\section{PROEFSCHRIFT}

Ter verkrijging van de graad van doctor aan de Universiteit Maastricht, op gezag van de Rector Magnificus, prof. dr. L.L.G. Soete, volgens het besluit van het College van Decanen, in het openbaar te verdedigen op dinsdag 2 december 2014 om 14:00 uur

door

Catherine Johanna Antonia Maria van Zelst 


\section{Promotores}

Prof. dr. Philippe Delespaul

Prof. dr. Jim van Os

\section{Beoordelingscommissie}

Prof. dr. Marten deVries (voorzitter)

Dr. Maarten Bak

Dr. Stynke Castelein (Lentis)

Dr. Machteld Marcelis

Prof. dr. Jaap van Weeghel (Tranzo, Tilburg University)

\section{Paranimfen}

Martine van Nierop

Peter Thijssen

The research presented in this thesis was performed at the School for Mental Health and Neuroscience, Department of Psychiatry \& Psychology, Maastricht University, Maastricht, the Netherlands. 
Voor Nienke

Voor mijn grootouders 
Voor een land zonder strijd, voor een hemel zonder wolken, voor een nieuwe tijd (Ken Je Dat Land - Boudewijn de Groot / Lennaert Nijgh) 


\section{Contents}

$\begin{array}{lr}\text { Introduction } & 9\end{array}$

\section{PART I STIGMA AND TRAUMA}

Chapter 1 Which environments for G $\mathrm{x}$ E? A user perspective of

the roles of trauma and structural discrimination in the onset and course of schizophrenia

Chapter 2 Stigmatization as an environmental risk in schizophrenia:

A user perspective

Chapter 3 Trauma and stigma as defeating experiences over the

life course interacting with genetic liability in schizophrenia

\section{PART II STEREOTYPE AWARENESS AND}

\section{DESTIGMATIZATION}

Chapter $4 \quad$ Stereotype awareness, self-esteem and psychopathology

in people with psychosis

Chapter 5 Associations between stereotype awareness, childhood

Dankwoord 



\section{Introduction}

\section{The mind examined}

Every child is influenced by the prejudice expressed by the people that surround them. Every child is also born curious, wanting to discover the world outside the safe haven of family and hometown. I was no different. For as long as I can remember, I wondered about things unfamiliar to me and I was curious about the things that were perceived as "different" by the adults that surrounded and influenced me.

From a young age on I was interested in physical health and illness, but it was during puberty that I got more aware of mental illness. At the age of 18 I thought a lot about what I wanted to major in in college. I wanted to explain both "normal" behavior and thoughts and behavior that were problematic for the individual exhibiting it and/or his or her surroundings. This, together with an ambition to help people, made me decide to move to Maastricht to study Mental Health Science. Moving to a new city to start a new chapter of my life, and living on my own for the first time, opened a new world for me.

From the beginning of my study, I developed an interest in psychiatry and the different ways in which mental illness can express itself. At some point, however, I started - like so many people with similar studies - recognizing symptoms in myself and others. What once had been purely scientific knowledge now all of a sudden became personally relevant as well, something that would throw me off balance for a while. Later, I learned to value and understand these experiences better.

During my study, I became particularly interested in psychotic disorders. I could hardly imagine what it would be like to be psychotic, but I was intrigued by experiences such as hallucinations and delusions. I became aware of how many people have to deal with these symptoms in their daily lives. At the same time, I developed a fear to get psychotic symptoms myself. Maybe it was the thought of losing control, of going crazy, that fuelled this fear.

Looking for options for my research internship, I got the opportunity to assist in a research project into bipolar disorder. While interviewing participants I listened to their stories about their own experiences and the ways they lived with depressive, manic and psychotic symptoms. Combined with my interest in schizophrenia and 
labeling, this inspired me to write my thesis for my other specialization, Health Education and Health Promotion, about stigma and schizophrenia. I looked into negative consequences of stigma for people with schizophrenia and wanted to make a difference for those who were known by few but stigmatized by many.

\section{From outsider to insider}

It was during my work on that thesis that I developed the first signs of psychosis myself. At the time, I could not and would not acknowledge that the things I was experiencing were psychotic symptoms. No matter how much my experiences sometimes resembled the symptoms I read about in textbooks, the term psychosis just could not be applicable to me. My symptoms worsened and the burden they caused increased. The psychotic episode I was experiencing would last more than six months. The turning point came when I started using medication. My symptoms slowly decreased and I took my first steps on the road to recovery.

\section{Recovery and work}

Many things can help during a recovery process. For me, writing, music, walking, careful planning, and the support of my wife all helped to get my life back on track. About a year after the most severe symptoms occurred I started looking for a job, and returned to the same department where I had done my research internship. Work has been a very important step in my recovery. It provided structure, a meaningful job in research, and colleagues.

\section{The balance between researcher and expert by experience}

With the question "How to cope with stigma as a service user?" in mind, I started writing a research proposal for my PhD-project about stigma resilience. From the start of this D-STIGMI project (Destigmatizing Mental Illness), my ideas about what it means to be a researcher with or without personal experiences in psychiatry, and of experts by experience in general, have developed. While emphasizing the scientific perspective, my own experience added value. Of course, I asked myself how to talk about this to others and what to disclose. I decided to keep work and private life separate, sometimes disclosing own experiences but most of the time letting them play a role in the background. This decision was challenged by the openness of experts by experience I worked with and of the 
participants of D-STIGMI. They made me see that using one's own experiences can be done in many ways and to many degrees. The same applies to disclosure.

\section{Dissertation}

I wrote my first papers from a user's perspective, using scientific knowledge and inspired by my views as an expert by experience. I presented stigma in society as an environmental factor that can play a role in gene-environment interactions in psychosis. I cover this in the first part of this dissertation. In the second part, I report on studies into stereotype awareness. This concept can mirror public stigma and precede or co-occur with internalization of stigma. I studied stereotype awareness with data of the GROUP project (Genetic Risk and Outcome of Psychosis). Coping with stereotype awareness about people with a mental illness or their family members can be a goal in interventions that aim to diminish the negative impact of stigma. In the general discussion of this dissertation I give a theoretical framework about stigma experiences, vulnerability and resilience. Everyone has vulnerabilities as well as capacities.

I also give an overview of the D-STIGMI project in which we compared a training that combines psycho-education with coping skills exercises with a newspaper reading group. I conclude the discussion with implications of the knowledge acquired in this $\mathrm{PhD}$ project for both research and clinical practice.

\section{Future}

Many promising studies and interventions about stigma are taking place. But there is still much more that needs to be done if we want to overcome stigma in mental health. My ambition is to continue doing research from a scientific perspective supported by knowledge based on experiences. With this dissertation I hope to make a contribution to knowledge about stigma and stereotypes in the lives of people with psychosis. Coping with psychosis and stigma is not always easy, but is definitely possible. 



\section{PART I \\ STIGMA AND TRAUMA}





\section{Chapter 1}

\section{Which environments for $G \times$ E ? A user perspective of the roles of trauma and structural discrimination in the onset and course of schizophrenia}

Published as:

van Zelst, C. (2008). Which environments for G x E? A user perspective on the roles of trauma and structural discrimination in the onset and course of schizophrenia. Schizophrenia Bulletin, 34(6), 1106-1110. 


\title{
Chapter 1
}

\begin{abstract}
Now that schizophrenia researchers may be moving from unilateral molecular genetic approaches to models including so-called gene-environment interactions, the question rises which environments may be considered for such research and how a user perspective may inform the field. It is argued that trauma and stigma, or perhaps better structural discrimination, represent 2 important environmental factors that deserve more attention. Experiential evidence, collected by users, suggests that trauma in childhood and/or adulthood, before, during, and after the onset of schizophrenia, as well as stigma/structural discrimination, may play important roles in the onset and course of the disorder. A certain reluctance on the part of the professional schizophrenia research community to take these variables as serious as, e.g., interesting but inconclusive etiological signals from prenatal hypoxia, prenatal folate deficiency, and prenatal toxoplasmosis is suggested. This article outlines the concepts of trauma and stigma and their negative consequences for the onset and course of schizophrenia. The importance of research into these factors and their possible relevance for gene-environment interactions is discussed. While gene-environment interaction research using these variables is indicated and may possibly prove productive, it is argued that such efforts may not be useful if no subsequent attempt is made to translate the results to the level of interventions, codeveloped by users, e.g. in the area of coping with the vicious circle of environmental adversity that users can become exposed to.
\end{abstract}

Keywords:

schizophrenia/psychosis/stigma/trauma/gene-environment

interaction/discrimination 


\section{Introduction}

Research has shown that both nature and nurture likely play an important role in the etiology of psychopathology (Tsuang, Bar et al. 2004). Although the scientific evidence for a genetic contribution to schizophrenia liability is very strong, molecular genetic research in schizophrenia is plagued by lack of replicable results and unresolved ethical issues from a user perspective (Mitchell 2000). Reviews by the psychiatric schizophrenia research community accepts a possible "precipitating" role of environmental factors, particularly cannabis use, prenatal infection or malnutrition, perinatal complications, and a history of winter birth (Tandon, Keshavan et al. 2008). However, work by users reporting experiential evidence tends to focus on environmental factors that are generally not seen as likely contributors to schizophrenia risk by the psychiatric research community: trauma and stigma - or perhaps better structural discrimination (Boevink 2006, Warner 2008). To the degree that these factors represent variables indexing pervasive exposure to social adversity, their relevance for gene-environment interactions involved in the onset and course of schizophrenia seems self-evident. Nevertheless, their possible contribution seems neglected in (scant) research about gene-environment interactions. In the current article, these 2 environmental factors are therefore highlighted, from a user perspective, as possible environmental risk factors with relevance for modeling gene-environment interactions and the development of new treatment strategies.

\section{Trauma}

The question rises to what degree the context of the psychiatric scientific debate surrounding research on trauma and schizophrenia is always entirely objective. For example, objectively inconclusive evidence of a putative association between toxoplasmosis and schizophrenia may be referred to as "examples of microbes that may have an etiological relationship to a major psychiatric disorder" (Yolken and Torrey 2008), while objectively inconclusive evidence of a putative association between trauma and major psychiatric disorder may be described as a possible "iatrogenic induction of memories of abuse by psychotherapists" (Torrey 2002). Conversely, evidence for a link between trauma and psychosis is sometimes presented somewhat uncritically (Read, van Os et al. 2005) and becomes, though still suggestive, less conclusive when analysed more conservatively (Morgan and 


\section{Chapter 1}

Fisher 2007). In any case, it may be important to accept that there are likely multiple pathways to psychosis. While trauma may play a role in a subgroup of people with psychosis, there are many others with no history of trauma. Even then, however, it is possible that some of these are prone to exacerbation and maintenance of their psychotic experiences by exposure to trauma associated with the subjective experience of psychosis or through subsequent victimization in the community (Walsh, Moran et al. 2003). To the degree that multiple risk factors may play a role, it seems important not to be a priori dismissive or selectively enthused by one at the expense of another, particularly with regard to outdated notions of separation along "biological" and "social" lines. Trauma is a broad concept which includes physical, sexual, emotional and psychological abuse, neglect, and bullying. Research has suggested that many people with schizophrenia have been exposed to significant trauma, both after and before the onset of their disorder (Bebbington, Bhugra et al. 2004). One inconclusive prospective study stands out (Spataro, Mullen et al. 2004), which has been suggested may be the result of the exposure being modified over the course of the study (Read and Hammersley 2005). Reviews suggest an excess of victimizing experiences in people with psychosis, many of which may have occurred during childhood (Read, van Os et al. 2005). The findings therefore are compatible with a social contribution to etiology (Bebbington, Bhugra et al. 2004). Nevertheless, there remain a number of conceptual and methodological issues with regard to the putative link between trauma and psychosis, indicating a need for more research before definitive conclusions can be drawn about whether childhood trauma is a cause for psychosis (Morgan and Fisher 2007). There are, however, sources suggesting plausibility for a relationship between the experience of trauma and psychosis (Morrison, Frame et al. 2003). Findings by Goff and colleagues (1991) suggest that in some chronically psychotic patients, childhood trauma and a tendency to dissociate may represent relevant factors contributing to age of onset and clinical characteristics. In their study, childhood abuse was associated with an early age of onset, more dissociative symptoms, and more frequent relapses. Goff and coworkers (1991) also suggest that in some chronically psychotic patients, a ongly disagree $(=0)$, disagree, agree, strongly agree $(=3)$. We used the individual's ual's mean item score for analyses. A higher mean score indicates hilleagues and Hammersley and colleagues (2003), who reported a relationship between 
histories of childhood trauma and histories of hallucinations, whereas Janssen and colleagues (2004) suggested, in a semi-prospective study, that early childhood trauma increases the risk for any positive psychotic symptom. In addition, at least one report is suggestive for an underlying mechanism of gene-environment interaction: Spauwen and colleagues (2006) reported data suggesting that exposure to psychological trauma may increase the risk of psychotic symptoms in people with a prior vulnerability to psychosis. Suggestively, another study reported an interaction between trauma and another risk factor associated with geneenvironment interaction in schizophrenia (cannabis) (Houston, Murphy et al. 2008). Lataster and colleagues (2006), in a cross-sectional study, found that victimization in childhood may give rise to subclinical expression of psychosis, as the earliest evidence of gene-environment interaction.

\section{Mechanisms of trauma}

Different mechanisms have been invoked to explain a possible association between trauma and schizophrenia. The experience of abuse may create a physical (Read, Perry et al. 2001) and/or psychological (Garety, Kuipers et al. 2001, Morrison 2001) vulnerability for the development of psychotic symptoms. The results of a study by Lataster and colleagues (2006) suggest that associations between childhood victimization and psychosis can be understood in a developmental framework of onset of at-risk mental states in early adolescence. Data from their study suggest that the traumatic experience of being bullied may feed the cognitive and biological mechanisms underlying formation of psychotic ideation (Lataster, van Os et al. 2006). Bak and colleagues (2005) similarly suggest that early experience of trauma may create lasting cognitive and affective vulnerabilities to develop clinical symptoms arising out of early, nonclinical psychotic experiences. The results of their study suggest that exposure to early trauma predisposes persons to suffer from more emotional distress associated with psychotic experiences and less perceived control over these experiences, compared with those without a traumatic history. Collip and colleagues (2008) invoke an underlying mechanism of "sensitization" - psychological and physical—explaining the link between trauma and psychosis. Trauma may also impact on the course of psychosis. Thus, child abuse causes prolonged suffering, and it may increase the distress 


\section{Chapter 1}

experienced by those who develop a psychotic mental illness in adulthood, resulting in worse outcomes (Morgan and Fisher 2007).

\section{Trauma in adulthood and trauma associated with psychosis}

In studying and trying to understand the impact of trauma in people with schizophrenia, trauma in adulthood should not be overlooked. People with severe mental illnesses are much more likely to be exposed to traumatic events than the general population. The increase in interest in the effects of adult trauma in people suffering from psychosis has extended not only to the traumatizing effect of psychotic experiences but also to the effect of treatment and societal rejection. The subjective impact of a psychotic breakdown can be profound and potentially result in loss of social roles, hopes, and aspirations and lead to stigmatization, trauma, and even elevated suicide risk (Tarrier, Khan et al. 2007). Therefore, the possible role of trauma in psychosis is complicated and may involve a vicious circle of traumatizing effects, starting with childhood exposure impacting on vulnerability and adult repeated retraumatization associated with the onset of psychotic symptoms and their treatment (Stastny and Lehmann 2007).

\section{Stigma}

Also important in understanding the course, but possibly also the onset, of schizophrenia is the concept of stigma - or perhaps better structural discrimination, against both patients and their relatives (Angermeyer, Schulze et al. 2003, Schulze and Angermeyer 2003). Following Link and Phelan (2001), I apply the term stigma when elements of labeling, stereotyping, separation, status loss, and discrimination co-occur in a power situation that allows the components of stigma to unfold. Emotional responses and reactions are also important in conceptualizing stigma (Link, Yang et al. 2004) and are therefore included in my conceptualization. Corrigan and Wassel (2008) differentiate between 3 kinds of stigma: public stigma, self-stigma, and label avoidance. These factors likely may all have an impact on the course and possibly also on the onset of schizophrenia. Schizophrenia has been found to be one of the most stigmatizing conditions (Rusch, Angermeyer et al. 2005). Experiences of stigma and discrimination can be found in many areas covering almost all aspects of daily life, including health and psychiatric care (Gonzalez-Torres, Oraa et al. 2007). Stigma creates a vicious cycle of alienation 
and discrimination. This in turn can lead to social isolation, inability to work, alcohol or drug abuse, homelessness, or excessive institutionalization, all of which decrease the chance of recovery (http://www.openthedoors.com). One of the main obstacles to the successful treatment (Gaebel and Baumann 2003) (http://www.openthedoors.com) and management of schizophrenia is the stigma that is oft associated with the disorder. The stigma associated with schizophrenia can therefore also have a negative impact on the course and outcome of the disorder (http://www.openthedoors.com).

Results of a qualitative study by Schulze and Angermeyer (2003) revealed 4 dimensions of stigma: interpersonal interaction, structural discrimination, public images of mental illness, and access to social roles. Stigma or anticipated stigma can also have consequences for labeling (Corrigan and Wassel 2008), which may affect not only the course but also the onset of schizophrenia. For example, a delay in treatment seeking because of anticipated stigma might cause a first episode to become more severe. Affective reactions like anger, depression, anxiety, feelings of isolation, guilt, and shame are also possible consequences of stigmatization (Dinos, Stevens et al. 2004). In addition, stigma has negative consequences in the domains of stress (Penn and Martin 1998) and relapse (Penn and Martin 1998, Catthoor, De Hert et al. 2003). Social interactions can be disrupted and occupational functioning can also be negatively affected. This, in turn, leads to a higher vulnerability to relapse (Catthoor, De Hert et al. 2003). Stigma associated with mental illness also harms the self-esteem of many people who have serious mental illnesses and may result in self-stigma. (Link, Struening et al. 2001). Selfstigma has a negative influence on individuals' social status, social network, and self-esteem (Vauth, Kleim et al. 2007). Stigma experiences have led many consumers to maintain a secrecy, which not only is uncomfortable but also may contribute to symptoms like anxiety, depression, and paranoia. Fears about stigma appear to result in reluctance to apply for jobs, education, insurance, or even to seek treatment. By making productive work less available, limiting treatment resources (e.g. insurance) and discouraging treatment seeking, by contributing to social isolation, and generating fears about disclosure and community rejection, stigma experiences may produce conditions that are virtually antithetical to the goals of recovery (Wahl 1999). Life goals and the opportunities that define them are impaired by the stigma of mental illness (Corrigan and Wassel 2008). 


\section{Chapter 1}

\section{Mechanisms of stigma}

Stigma can affect people with schizophrenia through different mechanisms. According to the vulnerability-stress-coping model, an interaction of vulnerability with stress-increasing life circumstances is responsible for the development and recurrence of psychotic episodes (Louwerens and van den Bosch 1999). This indicates that stigma may lead to worsening of symptoms and relapse via a pathway of stress. In this way, onset, course, and prognosis of the disorder can be influenced negatively. The stigma of severe mental illness likely interferes with the ability of people with severe mental illness to reintegrate into the community and may, by increasing ambient psychosocial stress, increase the likelihood of future relapse (Penn and Martin 1998).

Another mechanism through which stigma can influence the course of the disorder is self-fulfilling prophecies. These can be triggered by prejudice and negative stereotypes (Jussim, Palumbo et al. 2000). Many people experiencing their first episode of psychosis experience or perceive adverse social reactions even if the onset of their illness was very recent. There are potentially dramatic changes in how the person perceives him- or herself as a result of this episode. It is possible that biases in cognition relating to self and social knowledge may sensitize the individual to interpret future anomalous or stressful experiences in an increasingly psychotic manner. The nature of these appraisals may confer a psychological vulnerability, which increases the probability of subsequent psychotic episodes (Tarrier, Khan et al. 2007).

To the degree that stigma may lead to worsening of symptoms and relapse through a pathway of stress and to the degree that stress interacts with genetic vulnerability (van Winkel, Stefanis et al. 2008), gene-stigma interactions may be expected. To the degree that exposure to stigma is almost universally experienced by users, gene-stigma interactions may explain a large proportion of the variance in course and outcome. Nevertheless, even though the hypothesis of gene-stigma interactions is scientifically reasonable, no research to date, as far as I am aware [PUBMED: stigma AND (course OR outcome) AND schizophr*], has examined stigma in quantitative studies of course and outcome in schizophrenia, let alone as a variable making up gene-stigma interaction terms. This piece of data may be interesting by itself: it shows that stigma is examined essentially in a context of "social psychiatry," even though it probably represents the most severe stressor impacting 
on the physiology and psychology of patients with schizophrenia, the genetic constitution of whom will likely moderate the person's response to this enduring source of environmental adversity. In addition, stigma may interact with the person's earlier experience to trauma and the physiological and biological alterations induced by early adversity.

\section{Discussion}

Recovery from mental illness involves much more than recovery from the illness and its symptoms (Anthony 1993, Corring and Cook 2007) and does not necessarily involve the use of formal mental health services (Stastny and Lehmann 2007). Trauma and stigma are 2 factors people with schizophrenia very often have to deal with. Both are important environmental factors that should be included in research examining gene-environment interactions in schizophrenia. However, while gene-environment interactions may be important, this type of research ultimately only is relevant if it contributes to treatment. The negative impact trauma and stigmatization can have on the lives of people with schizophrenia makes intervention methods and research about these topics highly important. Coping with trauma and coping with stigma are both important elements of the general adaptation strategies employed by people with schizophrenia. Coping methods should therefore be incorporated in intervention methods for schizophrenia and psychosis and be developed in participation with users, who have knowledge about the impact and sources of environmental adversity. Intervening early in the course of the disorder to address self-stigmatization may enable young people to acquire positive attitudes toward themselves and the future (McCay, Beanlands et al. 2007). Trauma histories in subjects with psychotic experiences or people with a diagnosis of schizophrenia suggest a negative impact on coping resources that contributes to psychotic symptom formation. Attention for more "functional" coping resources may reduce the probability of progressing from a state of psychosis vulnerability to experiencing overt psychotic symptoms and reduction in social functioning (Bak, Krabbendam et al. 2005). Lysaker and colleagues (2007) suggest that stigma and symptoms are phenomena which exert complex influences over one another over time which may not be captured by cross-sectional assessment. This underlines the need for longitudinal research capturing coping experiences in the flow of daily life of users (Lardinois, Myin- 


\section{Chapter 1}

Germeys et al. 2007). In addition, the study of psychological mechanisms of psychotic symptoms is particularly important in view of the interest in preventing individuals from making "transitions" from nonclinical to clinical psychotic states (Cannon, Cadenhead et al. 2008). Also, research into protective factors in trauma and stigma is important, and including mental health consumers in research about their lives is not only likely to lead to a better therapeutic product for professionals but may also be beneficial for empowerment (Wahl 1999) and the development of user led forms of treatment and psycho-education. 


\section{References}

Angermeyer, M. C., B. Schulze and S. Dietrich (2003). "Courtesy stigma--a focus group study of relatives of schizophrenia patients." Soc Psychiatry Psychiatr Epidemiol 38(10): 593-602.

Anthony, W. A. (1993). "Recovery from mental illness: the guiding vision of the mental health service system in the 1990s." Psychosoc Rehabil J. 16(4): 11-23.

Bak, M., L. Krabbendam, I. Janssen, R. de Graaf, W. Vollebergh and J. van Os (2005). "Early trauma may increase the risk for psychotic experiences by impacting on emotional response and perception of control." Acta Psychiatr Scand 112(5): 360366.

Bebbington, P. E., D. Bhugra, T. Brugha, N. Singleton, M. Farrell, R. Jenkins, G. Lewis and H. Meltzer (2004). "Psychosis, victimisation and childhood disadvantage: evidence from the second British National Survey of Psychiatric Morbidity." Br J Psychiatry 185: 220-226.

Boevink, W. A. (2006). "From being a disorder to dealing with life: an experiential exploration of the association between trauma and psychosis." $\underline{\text { Schizophr Bull }}$ 32(1): 17-19.

Cannon, T. D., K. Cadenhead, B. Cornblatt, S. W. Woods, J. Addington, E. Walker, L. J. Seidman, D. Perkins, M. Tsuang, T. McGlashan and R. Heinssen (2008). "Prediction of psychosis in youth at high clinical risk: a multisite longitudinal study in North America." Arch Gen Psychiatry 65(1): 28-37.

Catthoor, K., M. De Hert and J. Peuskens (2003). "Stigma bij schizofrenie. Een literatuuroverzicht [Stigma and schizophrenia. A review]." Tijdschr Psychiatr 45: 1621-1626.

Collip, D., I. Myin-Germeys and J. Van Os (2008). "Does the concept of "sensitization" provide a plausible mechanism for the putative link between the environment and schizophrenia?" Schizophr Bull 34(2): 220-225.

Corrigan, P. W. and A. Wassel (2008). "Understanding and influencing the stigma of mental illness." J Psychosoc Nurs Ment Health Serv 46(1): 42-48.

Corring, D. J. and J. V. Cook (2007). "Use of qualitative methods to explore the quality-oflife construct from a consumer perspective." Psychiatr Serv 58(2): 240-244.

Dinos, S., S. Stevens, M. Serfaty, S. Weich and M. King (2004). "Stigma: the feelings and experiences of 46 people with mental illness. Qualitative study." $\underline{\mathrm{Br} J}$ Psychiatry 184: 176-181. 


\section{Chapter 1}

Gaebel, W. and A. E. Baumann (2003). "Interventions to reduce the stigma associated with severe mental illness: experiences from the open the doors program in Germany." Can J Psychiatry 48(10): 657-662.

Garety, P. A., E. Kuipers, D. Fowler, D. Freeman and P. E. Bebbington (2001). "A cognitive model of the positive symptoms of psychosis." Psychol Med 31(2): 189195.

Goff, D. C., A. W. Brotman, D. Kindlon, M. Waites and E. Amico (1991). "Self-reports of childhood abuse in chronically psychotic patients." Psychiatry Res 37(1): 73-80.

Gonzalez-Torres, M. A., R. Oraa, M. Aristegui, A. Fernandez-Rivas and J. Guimon (2007). "Stigma and discrimination towards people with schizophrenia and their family members. A qualitative study with focus groups." Soc Psychiatry Psychiatr Epidemiol 42(1): 14-23.

Hammersley, P., A. Dias, G. Todd, K. Bowen-Jones, B. Reilly and R. P. Bentall (2003). "Childhood trauma and hallucinations in bipolar affective disorder: preliminary investigation." Br J Psychiatry 182: 543-547.

Houston, J. E., J. Murphy, G. Adamson, M. Stringer and M. Shevlin (2008). "Childhood sexual abuse, early cannabis use, and psychosis: testing an interaction model based on the National Comorbidity Survey." Schizophr Bull 34(3): 580-585.

Janssen, I., L. Krabbendam, M. Bak, M. Hanssen, W. Vollebergh, R. de Graaf and J. van Os (2004). "Childhood abuse as a risk factor for psychotic experiences." Acta Psychiatr Scand 109(1): 38-45.

Jussim, L., P. Palumbo, C. Chatman, S. Madon and A. Smith (2000). Stigma and selffulfilling prophecies. The Social Psychology of Stigma. T. F. Heatherton, R. E. Kleck, M. R. Hebl and J. G. Hull. New York, The Guilford Press: 374-418.

Lardinois, M., I. Myin-Germeys, M. Bak, R. Mengelers, J. van Os and P. A. Delespaul (2007). "The dynamics of symptomatic and non-symptomatic coping with psychotic symptoms in the flow of daily life." Acta Psychiatr Scand 116(1): 71-75.

Lataster, T., J. van Os, M. Drukker, C. Henquet, F. Feron, N. Gunther and I. Myin-Germeys (2006). "Childhood victimisation and developmental expression of non-clinical delusional ideation and hallucinatory experiences: victimisation and non-clinical psychotic experiences." Soc Psychiatry Psychiatr Epidemiol 41(6): 423-428.

Link, B. G. and J. C. Phelan (2001). "Conceptualizing stigma." Annu Rev Sociol 27: 363385.

Link, B. G., E. L. Struening, S. Neese-Todd, S. Asmussen and J. C. Phelan (2001). "Stigma as a barrier to recovery: The consequences of stigma for the self-esteem of people with mental illnesses." Psychiatr Serv 52(12): 1621-1626.

Link, B. G., L. H. Yang, J. C. Phelan and P. Y. Collins (2004). "Measuring mental illness stigma." Schizophr Bull 30(3): 511-541. 
Louwerens, J. W. and R. J. van den Bosch (1999). Het kwetsbaarheid-stress-copingmodel. Behandelingsstrategieen bij schizofrenie. R. J. Van den Bosch, J. W. Louwerens and C. J. Slooff. Houten, The Netherlands, Bohn Stafleu Van Loghum: 9-16.

Lysaker, P. H., L. W. Davis, D. M. Warman, A. Strasburger and N. Beattie (2007). "Stigma, social function and symptoms in schizophrenia and schizoaffective disorder: associations across 6 months." Psychiatry Res 149(1-3): 89-95.

McCay, E., H. Beanlands, R. Zipursky and e. al. (2007). "A randomised controlled trial of a group intervention to reduce engulfment and self-stigmatisation in first episode schizophrenia." Aust E J Adv Ment Health 6(3): 1-9.

Mitchell, M. (2000). "What genetic advances might mean for the consumer in mental illness." Aust N Z J Psychiatry 34 Suppl: S198-200.

Morgan, C. and H. Fisher (2007). "Environment and schizophrenia: environmental factors in schizophrenia: childhood trauma--a critical review." Schizophr Bull 33(1): 3-10.

Morrison, A. P. (2001). "The interpretation of intrusions in psychosis: an integrative cognitive approach to hallucinations and delusions." Behav Cogn Psychother 29: 257-276.

Morrison, A. P., L. Frame and W. Larkin (2003). "Relationships between trauma and psychosis: a review and integration." Br J Clin Psychol 42(Pt 4): 331-353.

Penn, D. L. and J. Martin (1998). "The stigma of severe mental illness: some potential solutions for a recalcitrant problem." Psychiatr Q 69(3): 235-247.

Read, J. and P. Hammersley (2005). "Child sexual abuse and schizophrenia." Br J Psychiatry 186: 76; author reply 76.

Read, J., B. D. Perry, A. Moskowitz and J. Connolly (2001). "The contribution of early traumatic events to schizophrenia in some patients: a traumagenic neurodevelopmental model." Psychiatry 64(4): 319-345.

Read, J., J. van Os, A. P. Morrison and C. A. Ross (2005). "Childhood trauma, psychosis and schizophrenia: a literature review with theoretical and clinical implications." Acta Psychiatr Scand 112(5): 330-350.

Rusch, N., M. C. Angermeyer and P. W. Corrigan (2005). "Mental illness stigma: concepts, consequences, and initiatives to reduce stigma." Eur Psychiatry 20(8): 529-539.

Schulze, B. and M. C. Angermeyer (2003). "Subjective experiences of stigma. A focus group study of schizophrenic patients, their relatives and mental health professionals." Soc Sci Med 56(2): 299-312.

Spataro, J., P. E. Mullen, P. M. Burgess, D. L. Wells and S. A. Moss (2004). "Impact of child sexual abuse on mental health: prospective study in males and females." $\mathrm{Br} \mathrm{J}$ Psychiatry 184: 416-421. 


\section{Chapter 1}

Spauwen, J., L. Krabbendam, R. Lieb, H. U. Wittchen and J. van Os (2006). "Impact of psychological trauma on the development of psychotic symptoms: relationship with psychosis proneness." Br J Psychiatry 188: 527-533.

Stastny, P. and P. Lehmann (2007). Alternatives Beyond Psychiatry. Shrewsbury, UK, Peter Lehmann Publishing.

Tandon, R., M. S. Keshavan and H. A. Nasrallah (2008). "Schizophrenia, "just the facts" what we know in 2008. 2. Epidemiology and etiology." Schizophr Res 102(1-3): 1-18.

Tarrier, N., S. Khan, J. Cater and A. Picken (2007). "The subjective consequences of suffering a first episode psychosis: trauma and suicide behaviour." Soc Psychiatry Psychiatr Epidemiol 42(1): 29-35.

Torrey, E. F. (2002). "Early physical and sexual abuse associated with an adverse course of bipolar illness." Biol Psychiatry 52(8): 843; author reply 843-845.

Tsuang, M. T., J. L. Bar, W. S. Stone and S. V. Faraone (2004). "Gene-environment interactions in mental disorders." World Psychiatry 3(2): 73-83.

van Winkel, R., N. C. Stefanis and I. Myin-Germeys (2008). "Psychosocial stress and psychosis. A review of the neurobiological mechanisms and the evidence for genestress interaction." Schizophr Bull 34(6): 1095-1105.

Vauth, R., B. Kleim, M. Wirtz and P. W. Corrigan (2007). "Self-efficacy and empowerment as outcomes of self-stigmatizing and coping in schizophrenia." Psychiatry Res 150(1): 71-80.

Wahl, O. F. (1999). "Mental health consumers' experience of stigma." Schizophr Bull 25(3): 467-478.

Walsh, E., P. Moran, C. Scott, K. McKenzie, T. Burns, F. Creed, P. Tyrer, R. M. Murray, T. Fahy and U. K. Group (2003). "Prevalence of violent victimisation in severe mental illness." Br J Psychiatry 183: 233-238.

Warner, R. (2008). "Implementing local projects to reduce the stigma of mental illness." Epidemiol Psichiatr Soc 17(1): 20-25.

Whitfield, C. L., S. R. Dube, V. J. Felitti and R. F. Anda (2005). "Adverse childhood experiences and hallucinations." Child Abuse Negl 29(7): 797-810.

Yolken, R. H. and E. F. Torrey (2008). "Are some cases of psychosis caused by microbial agents? A review of the evidence." Mol Psychiatry 13(5): 470-479. 


\section{Chapter 2}

\section{Stigmatization as an environmental risk in schizophrenia: A user perspective}

Published as:

van Zelst, C. (2009). Stigmatization as an environmental risk in schizophrenia: a user perspective. Schizophr Bulletin, 35(2), 293-296. 


\begin{abstract}
Stigmatization represents a chronic negative interaction with the environment that most people with a diagnosis of schizophrenia face on a regular basis. Different types of stigma - public stigma, self-stigma, and label avoidance - may each have detrimental effects. In the present article, the possible consequences of stigma on onset, course, and outcome of schizophrenia are reviewed. Stigmatization may be conceptualized as a modifiable environmental risk factor that exerts its influence along a variety of different pathways, not only after the illness has been formally diagnosed but also before, on the basis of subtle behavioral expressions of schizophrenia liability. Integrating stigma-coping strategies in treatment may represent a cost-effective way to reduce the risk of relapse and poor outcome occasioned by chronic exposure to stigma. In addition, significant gains in quality of life may result if all patients with schizophrenia routinely receive information about stigma and are taught to use simple strategies to increase resilience vis-à-vis adverse, stigmatizing environments.
\end{abstract}

Keywords:

stigmatization/discrimination/schizophrenia/psychosis/environment/affective symptoms 


\section{Introduction}

Most individuals with a diagnosis of schizophrenia will be confronted with some form of stigmatization (Dickerson, Sommerville et al. 2002, Lee, Chiu et al. 2006). Stigmatization refers to a stereotyped set of negative attitudes, incorrect beliefs, and fears about the diagnosis schizophrenia that impact on how this syndrome is actually understood by others. It involves problems of knowledge (ignorance), attitudes (prejudice), and behavior (discrimination) and may be compounded by a scientifically inaccurate emphasis on biogenetic models of illness on the part of professionals (Angermeyer and Matschinger 2005, Schulze 2007, Thornicroft, Rose et al. 2007, Lincoln, Arens et al. 2008). Different types of stigma - public stigma, self-stigma, and label avoidance (Corrigan and Wassel 2008) - may have profoundly defeating consequences for the individual with a psychotic disorder (Schulze and Angermeyer 2003, Dinos, Stevens et al. 2004, Buizza, Schulze et al. 2007, Gonzalez-Torres, Oraa et al. 2007). Ritsher and Phelan (2004) suggest that the harmful effects of stigma may work through the internal perceptions, beliefs, and emotions of the stigmatized person, even above and beyond the effects of direct discrimination by others. Most of the research in the area of stigma is based on negative reactions faced by people with schizophrenia in studies on public attitudes or equivalent behavioral research. Research exploring the views of those exposed to stigma is less common. Although stigma is typically noted in professional guidelines, possible interventions are not proposed (Royal Australian and New Zealand College of Psychiatrists Clinical Practice Guidelines Team for the Treatment of Schizophrenia and Related Disorders, 2005). Therefore, in the present article, the consequences of stigma and their potentially negative impact on onset, course, and outcome of schizophrenia are examined not only from a scientific but also from a user perspective.

\section{Genetic risk, stigma, and schizophrenia}

Given the fact that the genetic vulnerability to schizophrenia is likely much more widely distributed than the illness itself, environmental factors impacting on vulnerable individuals may be invoked in order to explain the fact that not all vulnerable people make the transition to psychotic disorder (van Os, Rutten et al. 2008). What has received much less attention is the fact that some of these environmental factors may be provoked by the behavioral expression of genetic 


\section{Chapter 2}

vulnerability itself, a phenomenon known as gene-environment correlation or rGE. (van Os, Rutten et al. 2008). In some instances of rGE, the observed environmental risk factor merely represents a genetic epiphenomenon and is of no causal consequence itself. Sometimes, however, the environmental factor in rGE may still be of causal consequence. This latter scenario may be particularly relevant in the prodromal phase of the illness. According to the model described in this article and depicted in figure 1, some of the causal environmental risks for schizophrenia in the realm of social adversity represent structural negative interpersonal interactions in response to the behavioral expression of genetic risk. For example, a person may become stigmatized on the basis of odd speech or paranoid reactions that are the expression of schizophrenia liability. Although in this case stigmatization does not occur on the basis of a formal diagnosis, structural discrimination may nevertheless occur if the behavior is perceived, similar to schizophrenia, as different, out of the ordinary or strange. To the degree that stigma is a form of structural discrimination, the term may be of use in highlighting these early processes associated with schizophrenia liability and form a continuum with the stigma observed after illness onset and its negative consequences on illness course (figure 1). The central theme is that stigmatization/structural discrimination can be perceived as a component of social adversity, which can lead to social defeat and shape specific negative beliefs about the self and about others (Selten and Cantor-Graae, 2007). Presenting the negative interactions induced by liability and illness and their impact on, respectively, onset and course in one model may help focus attention on these issues and create more research culminating in risk-reducing strategies.

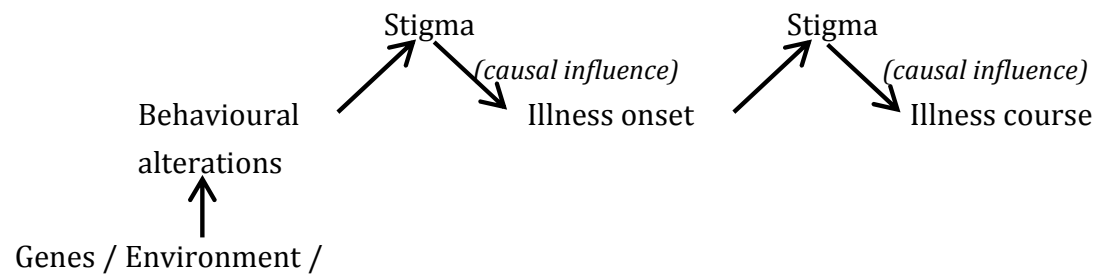

Genes x Environment

Figure 1. Extended model of stigma taking into account stigma induced by expression of both illness and behavioral alterations associated with illness liability. 


\section{Stigma and onset of schizophrenia}

Schizophrenia and other psychotic disorders are characterized by alterations in behavioral and cognitive development and, closer to the onset of the first psychotic episode, by an at-risk mental state or "prodromal" phase of illness in which a noticeable change from premorbid functioning occurs (Yung, Phillips et al. 2003). Different types of prodrome have been identified, and patients may progress from one type to another (Drake and Lewis 2005). For example, in one type, psychotic symptoms may appear intermittently but briefly. Subsequently, subclinical psychotic symptoms may persist for longer periods, and individuals may at some stage meet International Classification of Diseases, Tenth Revision, criteria for schizotypal personality disorder. Another type consists of neurotic symptoms, which commonly start before positive symptoms; individuals may meet criteria for depression or anxiety disorders (Drake and Lewis 2005). The question rises to what degree subtle negative interpersonal interactions induced by the changing behavior of individuals with an at-risk mental state may contribute to the risk of transition to a psychotic disorder. In other words, is it possible that subclinical psychotic experiences or other behavioral expressions of risk provoke stigmatizing reactions that further fuel the underlying psychotic process, increasing the risk for transition to a clinical psychotic episode?

There is face validity to the notion that people displaying behavioral expression of schizophrenia liability, whether it be in the form of a "prodrome," in the context of "schizotypal" low-grade psychotic experiences or even in the form of subtle developmental behavioral alterations long before illness onset (Welham, Isohanni et al. 2009), are likely to experience structural discrimination/stigmatization to a degree that it becomes relevant in terms of altering risk for transition to psychotic disorder. Although research is needed to address this question before firm conclusions can be drawn and interventions can be developed or adjusted, there is nevertheless some support for this notion in the literature. For example, Janssen et al (2003) examined whether perceived discrimination on the basis of skin color or ethnicity, gender, age, appearance, disability, or sexual orientation was prospectively associated with onset of psychotic symptoms. The results indicated that perceived discrimination predicted, in a dose-response fashion, incident delusional ideation. One way of explaining these findings is to hypothesize that subtle changes in the behavior of individuals with early expression of psychosis 


\section{Chapter 2}

liability give rise to negative social interactions and structural discrimination that in turn increase the risk for delusional ideation, e.g., by facilitating a paranoid attributional style (Garety, Kuipers et al. 2001) and/or by sensitization (and/or increased baseline activity) of the mesolimbic dopamine system (Collip, MyinGermeys and Van Os, 2008).

A prediction from this model is that in populations who suffer structural discrimination, the proportion of individuals with vulnerability for schizophrenia that actually makes the transition to psychotic disorder should be higher than in nonstigmatized populations. Recent work showing that the observed increased risk for schizophrenia in ethnic minority groups is contingent on the level of associated discrimination these groups are facing is compatible with this notion (Veling, Selten et al. 2007).

\section{Stigma and illness course}

\section{Course and outcome}

Although traditional follow-up studies of cohorts of patients to date have not included measures of stigma as a course modifier, there are nevertheless several reasons to assume that a strong association likely exists. Stigmatization may lead to negative discrimination, which in turn leads to numerous disadvantages in access to care, poor health service, and frequent life events that can damage self-esteem (Sartorius 2006). Stigmatization represents a chronic stressor and therefore, given evidence that stress triggers episodes of schizophrenia (Norman and Malla 1993, van Winkel, Stefanis et al. 2008), may act as a modifier of illness course. For example, there is some evidence that social stressors such as stigmatizing interactions and victimization can exacerbate symptoms and impact on social functioning (Perlick, Rosenheck et al. 2001, Yanos and Moos 2007). Furthermore, stigmatization, in the sense of label avoidance, can cause a delay in help or treatment-seeking behavior. In particular, the threat of social disapproval or diminished self-esteem that accompanies the label may account for underuse of services (Corrigan 2004). In addition, prejudice and discrimination related to schizophrenia have been observed to result in poor treatment compliance (Villares and Sartorius 2003). In a study about internalized stigma, Ritsher and Phelan 
(2004) found that alienation predicted depressive symptoms and reduced selfesteem, suggesting that it may be very difficult for individuals to escape, without assistance, a vicious circle of low self-esteem and alienation negatively impacting on each other (Ritsher and Phelan 2004). Awareness of illness may result in better functional outcome, but if awareness is accompanied by acceptance of stigmatizing beliefs, greater social dysfunction, less hope, and lower self-esteem become more likely (Lysaker, Roe et al. 2007).

\section{Psychopathology and quality of life}

Stigma leads to negative psychological outcomes among the mentally ill, including lowered self-esteem (Ritsher and Phelan 2004, Yang 2007), diminished selfefficacy (Yang 2007), and more depressive symptoms (Ritsher and Phelan 2004, Yang 2007). In a qualitative study by Dinos et al. (2004), the most common consequences of feelings of stigma revolved around anger, depression, fear, anxiety, feelings of isolation, guilt, embarrassment, and prevention from recovery or avoidance of help seeking. Around 1 in 3 patients with a diagnosis of schizophrenia has a social anxiety disorder, and it has been suggested that stigma may be closely related to social anxiety in schizophrenia. Thus, presence of social anxiety was predicted by greater experience of shame related to the psychotic diagnosis (Birchwood, Trower et al. 2007). This finding is highly relevant, given that higher levels of anxiety are associated with more hallucinations, withdrawal, depression, hopelessness, better insight, and poorer function and outcome (Huppert and Smith 2005, Lysaker and Salyers 2007). Finally, there is evidence that prejudice and discrimination related to schizophrenia result in an increased probability of misuse of alcohol and drugs (Villares and Sartorius 2003). Stigmatization can have detrimental consequences for both objective and subjective quality of life (QOL). Attributing one's problems to a mental illness is associated with reduced subjective QOL among persons with schizophrenia, much of which may be mediated by perceived stigma and lower self-esteem (Mechanic, McAlpine et al. 1994, Kunikata, Mino et al. 2005). Persons with mental health problems are often socially rejected, which can have negative consequences for their well-being in general and their self-esteem in particular (Verhaeghe, Bracke et al. 2008). Anxiety disorders may impose an additional burden to patients with 
schizophrenia, resulting in further decline in their subjective QOL (Braga, Mendlowicz et al. 2005).

\section{Interventions for modifiable risks?}

The data discussed above suggest that stigma may be seen in part as a modifiable risk factor for onset and persistence of psychosis; individual treatments may be developed to promote resilience and help individuals cope better. These interventions may not only be relevant for coping with stigma after illness onset but also before, if individuals show subtle alterations in behavior associated with schizophrenia liability. Although such interventions remain to be developed, the literature suggests a few simple guidelines that may be generally applicable. First, it is useful to differentiate between negative symptoms, depression, anxiety, and the consequences of stigmatization. For example, social isolation can be the result of all the above. Knowledge about (the consequences of) stigmatization is essential in understanding the coping strategies people with schizophrenia or other psychotic disorders apply. Conveying such knowledge to professionals during training and to patients and relatives during psycho-education would be a useful first step (Shin and Lukens 2002). Second, several studies have shown that the negative impact of stigma is greater if individuals use avoidant and isolating coping styles in the face of stigma (Ertugrul and Ulug 2004, Cooke, Peters et al. 2007, Gonzalez-Torres, Oraa et al. 2007, Vauth, Kleim et al. 2007, Lysaker, Salyers et al. 2008, Yanos, Roe et al. 2008). This suggests that induction of more active coping styles and sharing of experiences, possibly in the context of peer support (Davidson, Chinman et al. 2006), may be the ingredients of tailored treatments. Another important way of approaching stigma reduction is to offer ways of integration and recovery, e.g., through paid employment, which has been observed to reduce stigma. (Perkins, Raines et al. 2009). 


\section{References}

Royal Australian and New Zealand College of Psychiatrists Clinical Practice Guidelines Team for the Treatment of Schizophrenia and Related Disorders (2005). "Royal Australian and New Zealand College of Psychiatrists Clinical Practice Guidelines for the Treatment of Schizophrenia and Related Disorders." Aust N Z J Psychiatry 39: 1-30.

Angermeyer, M. C. and H. Matschinger (2005). "Causal beliefs and attitudes to people with schizophrenia. Trend analysis based on data from two population surveys in Germany." Br J Psychiatry 186: 331-334.

Birchwood, M., P. Trower, K. Brunet, P. Gilbert, Z. Iqbal and C. Jackson (2007). "Social anxiety and the shame of psychosis: a study in first episode psychosis." Behav Res Ther 45(5): 1025-1037.

Braga, R. J., M. V. Mendlowicz, R. P. Marrocos and I. L. Figueira (2005). "Anxiety disorders in outpatients with schizophrenia: prevalence and impact on the subjective quality of life." J Psychiatr Res 39(4): 409-414.

Buizza, C., B. Schulze, E. Bertocchi, G. Rossi, A. Ghilardi and R. Pioli (2007). "The stigma of schizophrenia from patients' and relatives' view: A pilot study in an Italian rehabilitation residential care unit." Clin Pract Epidemiol Ment Health 3: 23.

Collip, D., I. Myin-Germeys and J. Van Os (2008). "Does the concept of "sensitization" provide a plausible mechanism for the putative link between the environment and schizophrenia?" Schizophr Bull 34(2): 220-225.

Cooke, M., E. Peters, D. Fannon, A. P. Anilkumar, I. Aasen, E. Kuipers and V. Kumari (2007). "Insight, distress and coping styles in schizophrenia." Schizophr Res 94(13): 12-22.

Corrigan, P. (2004). "How stigma interferes with mental health care." Am Psychol 59(7): 614-625.

Corrigan, P. W. and A. Wassel (2008). "Understanding and influencing the stigma of mental illness." J Psychosoc Nurs Ment Health Serv 46(1): 42-48.

Davidson, L., M. Chinman, D. Sells and M. Rowe (2006). "Peer support among adults with serious mental illness: a report from the field." Schizophr Bull 32(3): 443-450.

Dickerson, F. B., J. Sommerville, A. E. Origoni, N. B. Ringel and F. Parente (2002). "Experiences of stigma among outpatients with schizophrenia." $\underline{\text { Schizophr Bull }}$ 28(1): 143-155.

Dinos, S., S. Stevens, M. Serfaty, S. Weich and M. King (2004). "Stigma: the feelings and experiences of 46 people with mental illness. Qualitative study." Br J Psychiatry 184: 176-181. 
Drake, R. J. and S. W. Lewis (2005). "Treatment of first episode and prodromal signs." Psychiatry 4: 55-58.

Ertugrul, A. and B. Ulug (2004). "Perception of stigma among patients with schizophrenia." Soc Psychiatry Psychiatr Epidemiol 39(1): 73-77.

Garety, P. A., E. Kuipers, D. Fowler, D. Freeman and P. E. Bebbington (2001). "A cognitive model of the positive symptoms of psychosis." Psychol Med 31(2): 189195.

Gonzalez-Torres, M. A., R. Oraa, M. Aristegui, A. Fernandez-Rivas and J. Guimon (2007). "Stigma and discrimination towards people with schizophrenia and their family members. A qualitative study with focus groups." Soc Psychiatry Psychiatr Epidemiol 42(1): 14-23.

Huppert, J. D. and T. E. Smith (2005). "Anxiety and schizophrenia: the interaction of subtypes of anxiety and psychotic symptoms." CNS Spectr 10(9): 721-731.

Janssen, I., M. Hanssen, M. Bak, R. V. Bijl, R. de Graaf, W. Vollebergh, K. McKenzie and J. van Os (2003). "Discrimination and delusional ideation." Br J Psychiatry 182: 71-76.

Kunikata, H., Y. Mino and K. Nakajima (2005). "Quality of life of schizophrenic patients living in the community: the relationships with personal characteristics, objective indicators and self-esteem." Psychiatry Clin Neurosci 59(2): 163-169.

Lee, S., M. Y. Chiu, A. Tsang, H. Chui and A. Kleinman (2006). "Stigmatizing experience and structural discrimination associated with the treatment of schizophrenia in Hong Kong." Soc Sci Med 62(7): 1685-1696.

Lincoln, T. M., E. Arens, C. Berger and W. Rief (2008). "Can antistigma campaigns be improved? A test of the impact of biogenetic vs psychosocial causal explanations on implicit and explicit attitudes to schizophrenia." Schizophr Bull 34(5): 984-994.

Lysaker, P. H., D. Roe and P. T. Yanos (2007). "Toward understanding the insight paradox: internalized stigma moderates the association between insight and social functioning, hope, and self-esteem among people with schizophrenia spectrum disorders." Schizophr Bull 33(1): 192-199.

Lysaker, P. H. and M. P. Salyers (2007). "Anxiety symptoms in schizophrenia spectrum disorders: associations with social function, positive and negative symptoms, hope and trauma history." Acta Psychiatr Scand 116(4): 290-298.

Lysaker, P. H., M. P. Salyers, J. Tsai, L. Y. Spurrier and L. W. Davis (2008). "Clinical and psychological correlates of two domains of hopelessness in schizophrenia." $\underline{J}$ Rehabil Res Dev 45(6): 911-919. 
Mechanic, D., D. McAlpine, S. Rosenfield and D. Davis (1994). "Effects of illness attribution and depression on the quality of life among persons with serious mental illness." Soc Sci Med 39(2): 155-164.

Norman, R. M. and A. K. Malla (1993). "Stressful life events and schizophrenia. I: A review of the research." Br J Psychiatry 162: 161-166.

Perkins, D. V., J. A. Raines, M. K. Tschopp and T. C. Warner (2009). "Gainful employment reduces stigma toward people recovering from schizophrenia." Community Ment Health J 45(3): 158-162.

Perlick, D. A., R. A. Rosenheck, J. F. Clarkin, J. A. Sirey, J. Salahi, E. L. Struening and B. G. Link (2001). "Stigma as a barrier to recovery: Adverse effects of perceived stigma on social adaptation of persons diagnosed with bipolar affective disorder." Psychiatr Serv 52(12): 1627-1632.

Ritsher, J. B. and J. C. Phelan (2004). "Internalized stigma predicts erosion of morale among psychiatric outpatients." Psychiatry Res 129(3): 257-265.

Sartorius, N. (2006). "Lessons from a 10-year global programme against stigma and discrimination because of an illness." Psychol Health Med 11(3): 383-388.

Schulze, B. (2007). "Stigma and mental health professionals: a review of the evidence on an intricate relationship." Int Rev Psychiatry 19(2): 137-155.

Schulze, B. and M. C. Angermeyer (2003). "Subjective experiences of stigma. A focus group study of schizophrenic patients, their relatives and mental health professionals." Soc Sci Med 56(2): 299-312.

Selten, J. P. and E. Cantor-Graae (2007). "Hypothesis: social defeat is a risk factor for schizophrenia?" Br J Psychiatry Suppl 51: s9-12.

Shin, S. K. and E. P. Lukens (2002). "Effects of psychoeducation for Korean Americans with chronic mental illness." Psychiatr Serv 53(9): 1125-1131.

Thornicroft, G., D. Rose, A. Kassam and N. Sartorius (2007). "Stigma: ignorance, prejudice or discrimination?" Br J Psychiatry 190: 192-193.

van Os, J., B. P. Rutten and R. Poulton (2008). "Gene-environment interactions in schizophrenia: review of epidemiological findings and future directions." Schizophr Bull 34(6): 1066-1082.

van Winkel, R., N. C. Stefanis and I. Myin-Germeys (2008). "Psychosocial stress and psychosis. A review of the neurobiological mechanisms and the evidence for genestress interaction." Schizophr Bull 34(6): 1095-1105.

Vauth, R., B. Kleim, M. Wirtz and P. W. Corrigan (2007). "Self-efficacy and empowerment as outcomes of self-stigmatizing and coping in schizophrenia." Psychiatry Res 150(1): 71-80. 
Chapter 2

Veling, W., J. P. Selten, E. Susser, W. Laan, J. P. Mackenbach and H. W. Hoek (2007).

"Discrimination and the incidence of psychotic disorders among ethnic minorities in The Netherlands." Int J Epidemiol 36(4): 761-768.

Verhaeghe, M., P. Bracke and K. Bruynooghe (2008). "Stigmatization and self-esteem of persons in recovery from mental illness: the role of peer support." Int J Soc Psychiatry 54(3): 206-218.

Villares, C. C. and N. Sartorius (2003). "Challenging the stigma of schizophrenia." $\underline{\text { Rev }}$ Bras Psiquiatr 25(1): 1-2.

Welham, J., M. Isohanni, P. Jones and J. McGrath (2009). "The antecedents of schizophrenia: a review of birth cohort studies." Schizophr Bull 35(3): 603-623.

Yang, L. H. (2007). "Application of mental illness stigma theory to Chinese societies: synthesis and new directions." Singapore Med J 48(11): 977-985.

Yanos, P. T. and R. H. Moos (2007). "Determinants of functioning and well-being among individuals with schizophrenia: an integrated model." Clin Psychol Rev 27(1): 5877.

Yanos, P. T., D. Roe, K. Markus and P. H. Lysaker (2008). "Pathways between internalized stigma and outcomes related to recovery in schizophrenia spectrum disorders." Psychiatr Serv 59(12): 1437-1442.

Yung, A. R., L. J. Phillips, H. P. Yuen, S. M. Francey, C. A. McFarlane, M. Hallgren and P. D. McGorry (2003). "Psychosis prediction: 12-month follow up of a high-risk ("prodromal") group." Schizophr Res 60(1): 21-32. 


\section{Chapter 3}

\section{Trauma and stigma as defeating experiences over the life course interacting with genetic liability in schizophrenia}

Published as:

van Zelst, C. (2010). Trauma and stigma as defeating experiences over the life course interacting with genetic liability in schizophrenia. European Psychiatric Review, 3(1), 35-38 


\begin{abstract}
Research suggests that many individuals with schizophrenia have been exposed to developmental trauma early in life, possibly representing a causal influence. In addition, schizophrenia is a syndrome in which stigma has a negative impact on the course and outcome of symptoms and associated disabilities. In combination, these two environmental risk factors are hypothesised to have a cumulative 'defeating' effect on the person over the life course. We suggest that the cumulative cascade of early trauma and later stigma interact with genetic vulnerability, producing onset and poor outcome of psychotic symptoms that subsequently may be interpreted as 'diagnostic' for the construct of schizophrenia. Research tracing the genetic origins interacting with the defeating effects of early and late adversity therefore represents the first step in unravelling the causal pathways of psychotic psychopathology and ultimately may feed personalised intervention strategies. It is argued that interventions focusing on education at the level of the individual, the group or the community may be most useful in breaking the defeating cycle induced by traumastigma-related adversity over the life course in vulnerable individuals. Interventions may also build on 'salutogenic' aspects associated with experience of life course adversity. In particular, personal education focusing on the concept of coping may be instrumental in bringing about changes in personal resources and providing a more empowered perspective in overcoming defeat.
\end{abstract}

Keywords:

schizophrenia/psychosis/stigmatisation/coping/trauma 
It is increasingly recognised that, in addition to the disorder itself, societal stigma and the self-stigma associated with it form a major source of chronic stress in schizophrenia. Stigma can be perceived as an environmental factor exerting major effects on anyone with a diagnosis of schizophrenia (Thornicroft, Brohan et al. 2009). The defeating nature of the experience of stigma closely resembles the effects of developmental trauma, an environmental risk factor that a proportion of people with schizophrenia have been exposed to and that may be of causal relevance (Read, van Os et al. 2005, Morgan and Fisher 2007). Although trauma exposure often occurs in childhood and adolescence, it can also occur in adulthood, e.g. as a consequence of experiencing psychosis. It is proposed that trauma and stigma in fact represent a cascade of related defeating experiences over the life course of the individual with a diagnosis of schizophrenia, occurring both before and after the onset of the illness. Given the fact that together they represent a major environmental source of adversity and that individual differences exist in the susceptibility to environmental adversity (Caspi and Moffitt 2006), research focusing on the interaction between individual vulnerability and environmental adversity is a natural and likely productive starting point of enquiry embodied by these two exposures. Another argument for studying stigma and trauma in the context of gene-environment $(\mathrm{GxE})$ interactions is that both have effects resembling 'defeat', and genetic influences in schizophrenia have been linked to neurobiological mechanisms associated with experimental defeat, involving dopamine neurotransmission (Selten and Cantor-Graae 2005). Thus, GxE interactions underlying the effects of trauma and stigma require further elucidation. In this article, the links between schizophrenia on the one hand and trauma and stigma on the other are reviewed. Not only are the adverse consequences of these two exposures acknowledged; another perspective is presented that incorporates possible positive, 'salutogenic' consequences of stigmatisation as well as coping methods to overcome it.

\section{The concept of differential sensitivity and gene-environment interactions}

The concept of differential sensitivity is key in explaining the aetiology of psychotic disorders. According to this concept, some individuals may be more sensitive than others to the psychotogenic effects of environmental risks associated 


\section{Chapter 3}

with defeat. The concept of differential sensitivity is close to the experience of users, as it offers an explanation of why a particular individual, given certain life circumstances, may develop symptoms and need for care. It is therefore important in both research and clinical care to examine and remediate the adverse effects of trauma and stigma in the context of personal vulnerability. That part of this vulnerability may be genetic should also be taken into account, as it stresses the fact that any effect of genes is probabilistic and mediated by environmental exposures. In addition, the concept of GxE interactions may enrich psychological models of causation associated with defeating effects of environmental exposures with biological models, thus broadening possible avenues of intervention. For example, psychological models posit the occurrence of trauma-induced intrusions that, in combination with personal vulnerability of altered source monitoring, may give rise to hallucinations; or the occurrence of a tendency to perceive hostility that, coupled with low self-esteem and certain cognitive biases, may give rise to paranoia (Morrison, Frame et al. 2003). On the other hand, biological models of GxE interactions converge on a final common pathway of dopamine sensitisation and dysregulation (EU-GEI 2008). Together, these models provide a way to personalise treatment geared towards the underlying vulnerability. Progress in the science of GxE interactions is hampered by the fact that it is a multidisciplinary exercise involving epidemiology, psychology, psychiatry, neuroscience, neuroimaging, pharmacology, biostatistics and genetics (van Os, Rutten et al. 2008), requiring cross-discipline collaboration. Nevertheless, this type of collaboration may be fruitful, as GxE interactions may be an important variable in explaining between-subject differences in the risk of developing psychosis following exposure to psychosocial stress (van Winkel, Stefanis et al. 2008). Furthermore, according to the psychosis-proneness-persistence impairment model, genetic background factors can affect the transitory expression of psychosis. It has been suggested that whether or not this will lead to a poor prognosis in terms of persistence and onset of clinical need will depend on the interaction between environmental exposures and genetic risk (van Os, Verkooyen et al. 2008), offering a perspective of early intervention in the presence of behavioural markers of genetic risk. A similar paradigm has been proposed in depression (Wichers, MyinGermeys et al. 2007). 


\section{The role of trauma}

Trauma is a broad concept that includes physical, sexual, emotional and psychological abuse, neglect and bullying. It is important to realize that while trauma may play a significant role in a subgroup of people with psychosis, there are many others with no or low levels of trauma (van Zelst 2008). In addition, individual differences in vulnerability to the psychotogenic effects of trauma, if any, must play a role as there are many people in the general population with significant exposure to developmental trauma who do not develop psychosis. An interesting but neglected factor is that one of the reasons why research about trauma - and stigma - is complicated is because both factors are 'taboo' to a degree; indeed, being traumatised may be stigmatising by itself.

\section{Childhood trauma, stress and adult health}

Childhood stress and trauma have been associated with psychopathology pertaining to a variety of psychiatric and somatic disorders (Felitti, Anda et al. 1998, Anda, Felitti et al. 2006). The results of a study by Weber and colleagues support the hypothesis of stress-sensitive periods during development, which may interact with genetic and other vulnerability factors in their influence on the onset and persistence of psychiatric disorders. Stress load in early childhood and before the onset of puberty - but not in adulthood - were more prominent in adult psychiatric patients than in non-psychiatric comparison subjects. However, it was noted by the authors that the relationship between childhood adverse experiences and psychopathology by itself does not demonstrate causality (Weber, Rockstroh et al. 2008).

There is controversy over whether childhood trauma is a causal factor in the development of psychosis (Read, van Os et al. 2005, Morgan and Fisher 2007). Many studies examining the association between trauma and psychosis necessarily lack adequate methodology (Bendall, Jackson et al. 2008) and whether valid and ethically acceptable experimental study of 'trauma' is possible is doubtful, although attempts have been made (Holmes and Bourne 2008, Laposa and Alden 2008). The data suggest that while the role of trauma in people with psychosis or schizophrenia should not be overestimated, and more research is needed, a history of trauma should always be actively and sensitively investigated in patients and acknowledged when present. 


\section{Chapter 3}

Review of recent studies of trauma and psychosis

Recent studies on the relationship between trauma and psychosis tend to be confirmative; however, the same methodological weaknesses largely apply. In a study by Thompson and colleagues, self-reported childhood trauma was common, particularly among high-risk patients from ethnic minorities for whom trauma was related to positive psychotic symptoms (Thompson, Kelly et al. 2009). Lataster and colleagues were the first to report a prospective association between childhood exposure to bullying and psychotic symptoms (Lataster, van Os et al. 2006) which was replicated in two other studies (Kelleher, Harley et al. 2008, Schreier, Wolke et al. 2009). Kelleher and co-workers (2008) found that adolescents who reported psychotic symptoms were significantly more likely to have been physically abused in childhood, to have been exposed to domestic violence and to be identified as a bully/victim (both a perpetrator and victim of bullying) than those who did not report such symptoms. The findings of these studies thus suggest that childhood trauma may increase the risk of psychotic experiences. Üçok and Bikmaz found a high prevalence of childhood trauma in patients with first-episode schizophrenia. Severity of childhood trauma also correlated with severity of positive symptoms. However, no control group was available (Ucok and Bikmaz 2007). In a study by Kilcommons and colleagues, severity of sexual abuse, as defined by the number of unwanted sexual events, was significantly associated with severity of psychotic experiences (Kilcommons, Morrison et al. 2008). Finally, exposure to trauma may reduce health-related quality of life (Lysaker and LaRocco 2009).

\section{Trauma, dissociation and psychosis}

Research from a variety of settings, when considered together, suggests that a history of trauma, particularly sexual trauma, prior to onset of illness in schizophrenia may be of clinical significance and may be linked with a particular clinical profile. For example, traumatic experiences preceding a psychotic episode can complicate its course (van Gerven, van der Hart et al. 2002). In addition, dissociation is often related to previous trauma and also occurs frequently in schizophrenia. Dissociation and psychosis may reflect a post-traumatic syndrome in some patients with a diagnosis of schizophrenia. In addition, dissociation may be specifically linked to childhood physical neglect in patients with a diagnosis of schizophrenia (Vogel, Spitzer et al. 2009). In another study, trauma and 
dissociation were associated with more severe symptoms of schizophrenia. Those with more severe schizophrenia and depression symptoms were also characterised by high levels of dissociation (Vogel, Schatz et al. 2009). Kilcommons and colleagues also found that dissociation, after controlling for the cumulative effect of sexual assault, significantly predicted both predisposition to visual hallucinations and emerging delusional distress. The authors concluded that people who respond to sexual abuse by dissociating may be more likely to experience an increased vulnerability to psychosis. The majority of sexually traumatised people experiencing psychotic phenomena in this sample did not seek help and continued to function in society despite such experiences (Kilcommons, Morrison et al. 2008).

Other symptoms in schizophrenia may be associated with trauma. In particular, individuals with trauma histories may experience more volatile fluctuations in levels of anxiety and hallucinations. The hallucinations they experience may be similar in content or theme to the trauma they experienced, and may be linked to symptoms of post-traumatic stress disorder (PTSD), greater difficulties sustaining work and the need for more medical care (Lysaker, Buck et al. 2007).

\section{Trauma and salutogenesis}

Although researchers have extensively studied the negative effects of trauma, much less attention has been paid to the possibility of (longer-term) positive impact of negative events (Tedeschi and Calhoun 1996). Exploring this impact as well as taking a salutogenic approach may lead to a fuller understanding of the impact of trauma. It was Antonovsky who coined the term 'salutogenesis', which literally means the origins of health; this author promoted the salutogenic approach (Griffiths 2009). In medical science, pathogenesis is important in order to understand diseases and disease development. Salutogenesis, on the other hand, contributes to our understanding of the development and maintenance of health (Suominen and Lindstrom 2008). The theory of salutogenesis gives a generic understanding of how sense of coherence (SOC) and coping may be created, and focuses on pathways that lead to successful coping and health (Langeland, Wahl et al. 2007). The SOC construct is a generalised orientation towards the world that perceives it, on a continuum, as comprehensible, manageable and meaningful (Antonovsky 1996). Another, related concept that may constitute an important 


\section{Chapter 3}

factor in recovery is resilience, which has been defined as the ability to adapt and cope successfully despite threatening or challenging situations. It is necessary to understand both vulnerability and resilience in order to meaningfully interpret the individual's personal adaptation to trauma (Agaibi and Wilson 2005).

\section{The role of stigma}

A key message of the campaign 'Time to Change' is that "Mental illness is our last taboo, such that the accompanying discrimination and exclusion can affect people in a way that many describe as worse than the illness itself." (Henderson and Thornicroft 2009). We are all likely to have to deal with mental illness at some time, whether in family members, work colleagues or ourselves (Gray 2002). We are also all likely to have to deal with stigma, directly or indirectly.

Stigma can take place when the elements of labelling, stereotyping, separation, status loss, discrimination (Link and Phelan 2001) and emotional reactions (Link, Yang et al. 2004) co-occur in a power situation that allows the components of stigma to unfold (Link and Phelan 2001). Individuals with severe mental illness must cope not only with the symptoms of their disease but also with social and self-stigma (Holmes and River 1998). In schizophrenia, stigma can have negative consequences in multiple domains of daily life (Schulze and Angermeyer 2003, van Zelst 2009). Three types of stigma - public stigma, self-stigma and label avoidance (Corrigan and Wassel 2008) - can each have its own as well as overlapping consequences for the individual.

The stigma associated with schizophrenia is pervasive, both in the community and among healthcare workers, and forms a real barrier to optimal recovery from the illness (Hocking 2003). Furthermore, stigma goes beyond the illness itself: it marks the people with the illness, their families across generations, institutions that provide treatment, psychotropic drugs and mental health workers (Sartorius 2007).

\section{Stigma, coping and salutogenesis}

While acknowledging all the possible negative consequences of stigma for the individual (and society), one should not forget that individuals have resources to cope with stigma. There is substantial evidence that SOC plays a central role in coping with stressors in the rehabilitation/ recovery process and that it contributes to mental health and psychosocial functioning. Rehabilitation services should 
ensure that they have rehabilitation goals that strengthen individuals' SOC (Griffiths 2009).

Shih studied the processes that stigmatised individuals use to successfully overcome the harmful consequences of stigmatisation, reviewing three processes: compensation, strategic interpretations of the social environment and focusing on multiple identities (Shih 2004). Stigmatised people have a vast array of responses to stressors resulting from their devalued social status, including emotional, cognitive, biological and behavioural responses. Understanding how stigmatised people cope with stigma requires that we take their perspective and study their responses to stress. Consideration of the diversity of stress and coping responses will be necessary to gain a complete understanding of the consequences of stigma (Miller and Kaiser 2001).

The recovery model refers to subjective experiences of optimism, empowerment and interpersonal support, and to a focus on collaborative treatment approaches, finding productive roles for users, peer support and reducing stigma (Warner 2009). An individual's capacity to counteract the stigma of mental illness, stigma resistance (SR), is considered as playing a crucial role in fighting stigma and lends itself well to the recovery model. The development of stigma-resisting beliefs might help individuals in their hope of finding a fulfilling life and their recovery from mental illness (Sibitz, Unger et al. 2011).

An important step in coping with severe mental illness is learning to recognise and modify self-stigmatising attitudes (Holmes and River 1998). A stress and coping perspective on stigma indicates that stigma-related events will be perceived as stressful only if they pose a threat that could exceed the person's resources for coping (Miller and Kaiser 2001).

Psychoeducation provides persons with information that assists them with developing a more realistic understanding of their illness, improves their ability to cope with the illness and facilitates their willingness to re-engage with their communities. (Holmes and River 1998).

\section{Positive consequences of stigma}

In an examination of chronic and non-chronic ex-psychiatric patients and involuntarily childless females, Herman and Miall found that responses to negative labelling/stigmatisation can be positive. Such responses include the legitimation of 
deviant behaviour and the deviant role, exemption from normal social roles and obligations, provision of interpersonal and social opportunities, strengthening of familial relationships, opportunities for career growth and change and personal growth experiences (Herman and Miall 1990).

\section{Discussion}

Genetic influences in schizophrenia have probabilistic effects by moderating the impact of defeating experiences over the life course. Poor outcome is not a necessary component of the natural history of schizophrenia (van Os and Kapur 2009, Warner 2009), and poor outcome may also reflect poor treatment. Thus, in order to improve the course and outcome of this syndrome, it is important to identify treatment opportunities as well as protective factors in dealing with stigma and trauma, particularly in individuals with prior vulnerability to their effects. Neither trauma nor stigma should be relegated to the status of taboo area, either in society or in treatment and prevention settings. Furthermore, it is important to assess the presence of dissociative and PTSD symptoms in individuals presenting with psychotic symptoms (Kilcommons, Morrison et al. 2008).

SOC, resilience and stigma resistance are important factors that deserve more attention. Exploring these in in-depth studies of trauma and stigma in schizophrenia, beyond quantitative main effects on onset and course in statistical models, may be helpful in understanding the life course of this syndrome, as well as possible treatment options. Applying the salutogenic approach in education and treatment may provide a more positive outlook not only for patients but also for their significant others and society in general.

A balanced view on stigma as well as trauma is needed in which both possible positive as well as negative consequences and the impact of coping, empowerment and recovery are acknowledged. Salutogenic factors in schizophrenia deserve attention in quantitative as well as qualitative research. In GxE interaction studies, it will be useful to examine salutogenic factors as well.

Acknowledgements: The research leading to these results has received funding from the European Community's Seventh Framework Programme under grant agreement No. HEALTH-F2-2009-241909 (Project EU-GEI). With thanks to Jim van Os for commenting on earlier versions of the manuscript. 


\section{References}

Agaibi, C. E. and J. P. Wilson (2005). "Trauma, PTSD, and resilience: a review of the literature." Trauma Violence Abuse 6(3): 195-216.

Anda, R. F., V. J. Felitti, J. D. Bremner, J. D. Walker, C. Whitfield, B. D. Perry, S. R. Dube and W. H. Giles (2006). "The enduring effects of abuse and related adverse experiences in childhood. A convergence of evidence from neurobiology and epidemiology." Eur Arch Psychiatry Clin Neurosci 256(3): 174-186.

Antonovsky, A. (1996). "The salutogenic model as a theory to guide health promotion." Health Promotion International 11(1): 11-18.

Bendall, S., H. J. Jackson, C. A. Hulbert and P. D. McGorry (2008). "Childhood trauma and psychotic disorders: a systematic, critical review of the evidence." Schizophrenia bulletin 34(3): 568-579.

Caspi, A. and T. E. Moffitt (2006). "Gene-environment interactions in psychiatry: joining forces with neuroscience." Nat Rev Neurosci 7(7): 583-590.

Corrigan, P. W. and A. Wassel (2008). "Understanding and influencing the stigma of mental illness." J Psychosoc Nurs Ment Health Serv 46(1): 42-48.

EU-GEI (2008). "European Network of Schizophrenia Networks for the Study of Gene Environment Interactions. Schizophrenia aetiology: do gene-environment interactions hold the key?" Schizophrenia Research 34(6): 1066-1082.

Felitti, V. J., R. F. Anda, D. Nordenberg, D. F. Williamson, A. M. Spitz, V. Edwards, M. P. Koss and J. S. Marks (1998). "Relationship of childhood abuse and household dysfunction to many of the leading causes of death in adults. The Adverse Childhood Experiences (ACE) Study." Am J Prev Med 14(4): 245-258.

Gray, A. J. (2002). "Stigma in psychiatry." J R Soc Med 95(2): 72-76.

Griffiths, C. A. (2009). "Sense of coherence and mental health rehabilitation." Clin Rehabil 23(1): 72-78.

Henderson, C. and G. Thornicroft (2009). "Stigma and discrimination in mental illness: Time to Change." Lancet 373(9679): 1928-1930.

Herman, N. J. and C. E. Miall (1990). "The positive consequences of stigma: two case studies in mental and physical disability." Qualitative Sociology 13(3): 251-269.

Hocking, B. (2003). "Reducing mental illness stigma and discrimination - everybody's business." Med J Aust 178 Suppl: S47-48.

Holmes, E. A. and C. Bourne (2008). "Inducing and modulating intrusive emotional memories: a review of the trauma film paradigm." Acta Psychol (Amst) 127(3): 553-566. 


\section{Chapter 3}

Holmes, E. P. and L. P. River (1998). "Individual strategies for coping with the stigma of severe mental illness." Cogn Behav Pract 5: 231-239.

Kelleher, I., M. Harley, F. Lynch, L. Arseneault, C. Fitzpatrick and M. Cannon (2008). "Associations between childhood trauma, bullying and psychotic symptoms among a school-based adolescent sample." Br J Psychiatry 193(5): 378-382.

Kilcommons, A. M., A. P. Morrison, A. Knight and F. Lobban (2008). "Psychotic experiences in people who have been sexually assaulted." Soc Psychiatry Psychiatr Epidemiol 43(8): 602-611.

Langeland, E., A. K. Wahl, K. Kristoffersen and B. R. Hanestad (2007). "Promoting coping: salutogenesis among people with mental health problems." Issues Ment Health Nurs 28(3): 275-295.

Laposa, J. M. and L. E. Alden (2008). "The effect of pre-existing vulnerability factors on a laboratory analogue trauma experience." J Behav Ther Exp Psychiatry 39(4): 424435.

Lataster, T., J. van Os, M. Drukker, C. Henquet, F. Feron, N. Gunther and I. Myin-Germeys (2006). "Childhood victimisation and developmental expression of non-clinical delusional ideation and hallucinatory experiences: victimisation and non-clinical psychotic experiences." Soc Psychiatry Psychiatr Epidemiol 41(6): 423-428.

Link, B. G. and J. C. Phelan (2001). "Conceptualizing stigma." Annu Rev Sociol 27: 363385.

Link, B. G., L. H. Yang, J. C. Phelan and P. Y. Collins (2004). "Measuring mental illness stigma." Schizophr Bull 30(3): 511-541.

Lysaker, P. H., K. D. Buck and V. A. LaRocco (2007). "Clinical and psychosocial significance of trauma history in the treatment of schizophrenia." J Psychosoc Nurs Ment Health Serv 45(8): 44-51.

Lysaker, P. H. and V. A. LaRocco (2009). "Health-related quality of life and trauma history in adults with schizophrenia spectrum disorders." J Nerv Ment Dis 197(5): 311315.

Miller, C. T. and C. R. Kaiser (2001). "A theoretical perspective on coping with stigma." J Soc Issues 57(1): 73-92.

Miller, C. T. and C. R. Kaiser (2001). "A theoretical perspective on coping with stigma." Journal of Social Issues 57(1): 73-92.

Morgan, C. and H. Fisher (2007). "Environment and schizophrenia: environmental factors in schizophrenia: childhood trauma--a critical review." Schizophr Bull 33(1): 3-10.

Morrison, A. P., L. Frame and W. Larkin (2003). "Relationships between trauma and psychosis: a review and integration." Br J Clin Psychol 42(Pt 4): 331-353. 
Read, J., J. van Os, A. P. Morrison and C. A. Ross (2005). "Childhood trauma, psychosis and schizophrenia: a literature review with theoretical and clinical implications." Acta Psychiatr Scand 112(5): 330-350.

Sartorius, N. (2007). "Stigma and mental health." Lancet 370(9590): 810-811.

Schreier, A., D. Wolke, K. Thomas, J. Horwood, C. Hollis, D. Gunnell, G. Lewis, A. Thompson, S. Zammit, L. Duffy, G. Salvi and G. Harrison (2009). "Prospective study of peer victimization in childhood and psychotic symptoms in a nonclinical population at age 12 years." Arch Gen Psychiatry 66(5): 527-536.

Schulze, B. and M. C. Angermeyer (2003). "Subjective experiences of stigma. A focus group study of schizophrenic patients, their relatives and mental health professionals." Soc Sci Med 56(2): 299-312.

Selten, J. P. and E. Cantor-Graae (2005). "Social defeat: risk factor for schizophrenia?" $\mathrm{Br}$ J Psychiatry 187: 101-102.

Shih, M. (2004). "Positive stigma: examining resilience and empowerment in overcoming stigma." The ANNALS of the Americal Academy of Political and Social Science 591: $175-185$.

Sibitz, I., A. Unger, A. Woppmann, T. Zidek and M. Amering (2011). "Stigma resistance in patients with schizophrenia." Schizophr Bull 37(2): 316-323.

Suominen, S. and B. Lindstrom (2008). "Salutogenesis." Scand J Public Health 36(4): 337339.

Tedeschi, R. G. and L. G. Calhoun (1996). "The Posttraumatic Growth Inventory: measuring the positive legacy of trauma." J Trauma Stress 9(3): 455-471.

Thompson, J. L., M. Kelly, D. Kimhy, J. M. Harkavy-Friedman, S. Khan, J. W. Messinger, S. Schobel, R. Goetz, D. Malaspina and C. Corcoran (2009). "Childhood trauma and prodromal symptoms among individuals at clinical high risk for psychosis." Schizophr Res 108(1-3): 176-181.

Thornicroft, G., E. Brohan, D. Rose, N. Sartorius, M. Leese and I. S. Group (2009). "Global pattern of experienced and anticipated discrimination against people with schizophrenia: a cross-sectional survey." Lancet 373(9661): 408-415.

Ucok, A. and S. Bikmaz (2007). "The effects of childhood trauma in patients with firstepisode schizophrenia." Acta Psychiatr Scand 116(5): 371-377.

van Gerven, M., O. van der Hart, E. R. S. Nijenhuis and T. Kuipers (2002).

"Overzichtsartikel. Psychose, trauma en traumagerelateerde psychopathologie." Tijdschrift voor Psychiatie 44(8): 533-540.

van Os, J. and S. Kapur (2009). "Schizophrenia." Lancet 374(9690): 635-645.

van Os, J., B. P. Rutten and R. Poulton (2008). "Gene-environment interactions in schizophrenia: review of epidemiological findings and future directions." Schizophr Bull 34(6): 1066-1082. 


\section{Chapter 3}

van Os, J., R. Verkooyen, M. Hendriks and e. al. (2008). "De ontogenese van psychotische stoornis; een model van kwetsbaarheid voor psychose, persistentie en belemmering." Tijdschrift voor Psychiatrie 50: 77-83.

van Winkel, R., N. C. Stefanis and I. Myin-Germeys (2008). "Psychosocial stress and psychosis. A review of the neurobiological mechanisms and the evidence for genestress interaction." Schizophr Bull 34(6): 1095-1105.

van Zelst, C. (2008). "Which environments for G x E? A user perspective on the roles of trauma and structural discrimination in the onset and course of schizophrenia." Schizophr Bull 34(6): 1106-1110.

van Zelst, C. (2009). "Stigmatization as an environmental risk in schizophrenia: a user perspective." Schizophr Bull 35(2): 293-296.

Vogel, M., D. Schatz, C. Spitzer, P. Kuwert, B. Moller, H. J. Freyberger and H. J. Grabe (2009). "A more proximal impact of dissociation than of trauma and posttraumatic stress disorder on schneiderian symptoms in patients diagnosed with schizophrenia." Compr Psychiatry 50(2): 128-134.

Vogel, M., C. Spitzer, P. Kuwert, B. Moller, H. J. Freyberger and H. J. Grabe (2009).

"Association of childhood neglect with adult dissociation in schizophrenic inpatients." Psychopathology 42(2): 124-130.

Warner, R. (2009). "Recovery from schizophrenia and the recovery model." Curr Opin Psychiatry 22(4): 374-380.

Weber, K., B. Rockstroh, J. Borgelt, B. Awiszus, T. Popov, K. Hoffmann, K. Schonauer, H. Watzl and K. Propster (2008). "Stress load during childhood affects psychopathology in psychiatric patients." BMC Psychiatry 8: 63.

Wichers, M. C., I. Myin-Germeys, N. Jacobs, F. Peeters, G. Kenis, C. Derom, R. Vlietinck, P. Delespaul and J. van Os (2007). "Evidence that moment-to-moment variation in positive emotions buffer genetic risk for depression: a momentary assessment twin study." Acta Psychiatr Scand 115(6): 451-457. 


\section{PART II \\ STEREOTYPE AWARENESS AND \\ DESTIGMATIZATION}





\section{Chapter 4}

\section{Stereotype awareness, self-esteem and psychopathology in people with psychosis}

Published as:

van Zelst, C., van Nierop, M., Oorschot, M., Myin-Germeys, I., van Os, J., Delespaul, P., for GROUP. (2014). Stereotype awareness, self-esteem and psychopathology in people with psychosis. PLoS One, 9(2), e88586. 


\begin{abstract}
Introduction: Stigma is an important environmental risk factor for a variety of outcomes in schizophrenia. In order to understand and remediate its effects, research is required to assess how stigma experiences are processed at the level of the individual. To this end, stereotype awareness (SA) with respect to people with mental illness and their families was explored in persons with psychotic disorder.

Method: Data from the Dutch Genetic Risk and OUtcome of Psychosis project (GROUP) were analyzed. SA was measured using scales that assess a respondent's perception of common opinions about people with a mental illness and their families.

Results: People with higher level of self-esteem were less aware of stereotypes about patients and families. People with more severe psychopathology reported more awareness of stereotypes about families, not about patients.

Conclusion: Enhancing psychological resources, by increasing self-esteem and the ability to cope with symptoms, can be targeted to diminish stereotype threat and improve stigma resilience. Interventions can be tailored to individual differences to increase their impact. Furthermore, in order to diminish detrimental consequences of negative stereotypes, mental health professionals, health educators and experts by experience can inform the public about mental illness and stigma.
\end{abstract}




\section{Introduction}

Mental illness is surrounded by negative stereotypes. Schneider defined stereotypes as "qualities perceived to be associated with particular groups or categories of people" (2004, p. 24). When stereotypes are related to group characteristics, they can lead to public stigma; self-stigma may arise when they relate to beliefs about the self (Corrigan and Kleinlein 2005). Mental illness related stereotypes center around being (un)responsible, dangerous and dependent, having a poor prognosis and poor social skills (Hayward and Bright 1997) and, at the positive side, being creative (Angermeyer and Matschinger 2004). According to Ajtony (2011), stereotyping is not inherently wrong; it is a natural function of the human / cultural mind and is therefore morally neutral in itself. However, uncritical stereotyping can result in negative consequences for individuals and society. This plays a central role in the development, justification, maintenance, and perpetuation of stigmatization (Biernat and Dovidio 2000), and contributes to discrimination.

The 'modified labeling theory' by Link and colleagues (1989) considered societal conceptions of devaluation-discrimination of "mental patients" as the first step in the labeling process. People labeled with psychiatric problems who live in a culture where stereotypes about mental illness prevail may anticipate and internalize attitudes that reflect devaluation and discrimination (Corrigan, Larson et al. 2009). Once labeled, an individual's societal conceptions become relevant to the self, altering the individual's response (cognitive, emotional and behavioral) in daily life through self-stigma.

Corrigan, Watson \& Barr (2006) defined Link's process of perceived discrimination as stereotype awareness (SA): "the person is aware of the general negative beliefs about mental illness held by one's culture" (p.876). This concept can be assessed with the Devaluation of Consumers Scale and the Devaluation of Consumers Families Scale (DCS and DCFS; Struening et al., 2001).

\section{Stigma vulnerability and stereotype awareness}

Anyone - with or without mental health complaints - is biased to a degree in how feedback is perceived and interpreted. The beliefs one holds about stereotypes in society, or "what most people think", may be biased. The extent to which stereotypes are prevalent in society can be over- or underestimated easily. Negative schemas and psychopathology may increase this bias. Overestimation of the 


\section{Chapter 4}

presence of stereotypes in society or attaching more value to them, or to the belief of "what most people think" may indicate stigma vulnerability. Psychological and social skills that protect against negative schemas, negative underlying assumptions or bias in information processing and perception of stereotypes (or SA) may help an individual to become more stigma-resilient. Rüsch and colleagues (2009) state that identifying vulnerability and resilience factors to stress due to stigma can help reduce the impact of stigma on persons with schizophrenia and other diagnoses of mental illness. In this study, we explore the associations of self-esteem and psychopathology with the individual's awareness of stereotypes.

Previous work on SA and self-esteem showed that self-esteem can be influenced negatively by SA (Link, Struening et al. 2001). Furthermore, cognitive processing, emotional thresholds and behavioral responses that are related to psychopathology, may further influence stigma susceptibility. Both stereotypes about patients as well as their families may be relevant to people with psychosis. Therefore, we aimed to investigate SA about patients as well as SA about their families, self-esteem and psychopathology in this group.

\section{Methods}

Data pertain to second wave measures of the Genetic Risk and OUtcome of Psychosis (GROUP) study, an ongoing longitudinal multicenter study in Europe. In selected representative geographical areas of the Netherlands and (Dutch speaking part of) Belgium, patients were identified through clinicians working in regional psychosis departments or academic centers. The patients presenting consecutively at these services either as outpatients or inpatients were recruited for the study.

\section{Ethics statement}

Persons identified as potentially eligible and deemed capable of providing informed consent by their clinician were given detailed explanation of the study procedures and were asked for written informed consent for detailed assessment and for contacting their first-degree family members (brothers, sisters, parents). Written informed consent was also obtained from the next of kin, caretakers, or guardians of those aged 16-17 years. Before written informed consent was obtained, persons had the opportunity to think about and ask questions about participation. They could talk about the study with an independent physician who 
was not involved in the study. All potential participants who declined to participate or otherwise did not participate were eligible for treatment (if applicable) and were not disadvantaged in any way in the case of non-participation. The study protocol was approved by the Ethical Review Board of the University Medical Centre Utrecht.

\section{Sample}

For the current analyses, we used the subsample of the second wave of the GROUP Maastricht patients sample $(\mathrm{N}=219)$. This subsample has add-on scales measuring self-esteem and SA. Data of patients with at least $70 \%$ answers on SA-scales were used. Inclusion criteria for the Maastricht add-on study were: age range of 16-50 years (at first wave), clinical diagnosis of psychotic disorder according to the Diagnostic and Statistical Manual of Mental Disorders, fourth edition (DSM-IV) criteria (APA 2000), good command of the Dutch language and able and willing to give written informed consent.

\section{Materials}

Stereotype awareness was measured using the Devaluation of Consumers Scale (DCS, 8 items) and the Devaluation of Consumers Families Scale (DCFS, 7 items) (Struening, Perlick et al. 2001). These scales assess a respondent's perception of what most other people believe about people with a mental illness (DCS) and their families (DCFS). We use two scales because they assess slightly different domains. All items are rated on a 4-point Likert Scale: strongly disagree $(=1)$, disagree, agree, strongly agree $(=4)$. In the statistical analyses, mean scores of the scales were used as outcomes (overall scores). The higher the score on the DCS or DCFS, the more the person is aware of the general negative beliefs about mental illness held by one's culture.

Self-esteem was measured using the 10-item Rosenberg Self-Esteem scale (RSES; Rosenberg 1965). Items are rated on a 4-point Likert Scale: strongly disagree $(=0)$, disagree, agree, strongly agree $(=3)$. We used the individual's mean item score for analyses. A higher mean score indicates higher self-esteem. Psychopathology was measured with an extended version of the Brief Psychiatric Rating Scale (28-item BPRS; Overall and Gorham 1962, Ventura, Lukoff et al. 1993, Delespaul, Bak et al. 2008). Information on both frequency and severity of 
symptoms in the two weeks before the interview was used for scoring. Items are rated on a 7-point ordinal scale. Analyses used the individual's mean score of all 28 items.

\section{Statistical analysis}

Linear regression analysis was conducted with scores on DCS and DCFS respectively for the assessment of stereotype awareness as dependent variables and as independent variables, the RSES as a measure of self-esteem (in model 1), to which was added BPRS severity in order to assess associations with psychopathology (model 2). Gender, age, illness duration and ethnicity were added as a priori confounders in all analyses. Statistical analysis was carried out using STATA 11.2 (StataCorp. 2009).

\section{Results}

186 patients filled in more than $70 \%$ of items in the DCS, and 184 did so for the DCFS. Of the 186 patients, 129 were men (69\%). Mean age was 29.8 years (range 18-53). Most patients were diagnosed with psychosis spectrum disorder (98\%). Mean duration of illness was 7.7 years (range 2.1-29.1). 89\% was of white ethnic group, $8 \%$ of mixed ethnic group, $1 \%$ of Moroccan ethnicity, $1 \%$ of Surinamese ethnicity, and $1 \%$ of other ethnic group. BPRS overall score was 1.5 (range 1-3.2), RSES overall score was 2.0 (0.5-3.0). On the devaluation scales, mean overall scores were 2.6 (1-4) for DCS and 2.2 (1-3.7) for DCFS. The correlation between DCS and DCFS overall scores was 0.56 . The correlation between RSES score and BPRS score was 0.36 .

\section{Stereotype awareness}

Cronbach's alphas of the DCS and DCFS were respectively 0.83 and 0.86 , indicating good reliability. A principal component analysis (PCA) with oblique rotation (oblimin) was conducted to explore associations in the item set. We identified factors with eigenvalues larger or equivalent to 0.9. This analysis revealed one factor for DCS and two factors for DCFS. Eigenvalues of these factors were 3.84 for DCS and 3.81 and 0.94 for DCFS.

Studying the extent to which patients agreed and disagreed with statements, the mean percentage of agreement with the DCS-items was 58\%, ranging from 39\% 
for the item "Most people feel that having a mental illness is worse than being addicted to drugs" to $71 \%$ for the item "Most people think less of a person who has been a patient in a mental hospital" (Table 1).

\begin{tabular}{|l|l|l|}
\hline DCS & $\begin{array}{l}\text { Disagree/ } \\
\text { Strongly } \\
\text { disagree (\%) }\end{array}$ & $\begin{array}{l}\text { Agree/ } \\
\text { Strongly } \\
\text { agree (\%) }\end{array}$ \\
\hline $\begin{array}{l}\text { 1. Most people would not accept a person who once had a serious } \\
\text { mental illness as a close friend }\end{array}$ & 58.82 & 41.18 \\
\hline $\begin{array}{l}\text { 2. Most people think that a person with a serious mental illness is } \\
\text { dangerous and unpredictable }\end{array}$ & 41.18 & 58.82 \\
\hline $\begin{array}{l}\text { 3. Most people feel that having a mental illness is worse than being } \\
\text { addicted to drugs }\end{array}$ & 60.75 & 39.25 \\
\hline $\begin{array}{l}\text { 4. Most people look down on someone who once was a patient in a } \\
\text { mental hospital }\end{array}$ & 33.33 & 66.67 \\
\hline $\begin{array}{l}\text { 5. Most employers will not hire a person who once had a serious } \\
\text { mental illness if he or she is qualified for the job }\end{array}$ & 33.87 & 66.13 \\
\hline $\begin{array}{l}\text { 6. Most people think less of a person who has been a patient in a } \\
\text { mental hospital }\end{array}$ & 29.03 & 70.97 \\
\hline $\begin{array}{l}\text { 7. Most people feel that entering psychiatric treatment is a sign of } \\
\text { personal failure }\end{array}$ & 45.16 & 54.84 \\
\hline $\begin{array}{l}\text { 8. Most young women would not marry a man who has been treated } \\
\text { for a serious mental disorder }\end{array}$ & 37.63 & 57.5 \\
\hline $\begin{array}{l}\text { Mean percentage of participants } \\
\text { Table }\end{array}$ & & 62.37 \\
\hline
\end{tabular}

Table 1: Patient's responses on statements of the DCS $(N=186)$.

On the DCFS, most answers indicated disagreement with the statements. The mean percentage of agreement was 31\% ranging from 26\% for both of the items "Most people in my community would rather not be friends with families that have a relative who is mentally ill living with them" and "Most people do blame parents for the mental illness of their children" to $41 \%$ for the item "Most people would not treat families with a member who is mentally ill in the same way they treat other families" (Table 2). 


\begin{tabular}{|l|l|l|}
\hline DCFS & $\begin{array}{l}\text { Disagree/ } \\
\text { Strongly } \\
\text { disagree (\%) }\end{array}$ & $\begin{array}{l}\text { Agree/ } \\
\text { Strongly } \\
\text { agree (\%) }\end{array}$ \\
\hline $\begin{array}{l}\text { 9. Most people in my community would rather not be friends with } \\
\text { families that have a relative who is mentally ill living with them }\end{array}$ & 74.46 & 25.54 \\
\hline $\begin{array}{l}\text { 10. Most people believe that parents of children with a mental illness } \\
\text { are not as responsible and caring as other parents }\end{array}$ & 68.48 & 31.52 \\
\hline $\begin{array}{l}\text { 11. Most people look down on families that have a member who is } \\
\text { mentally ill living with them }\end{array}$ & 69.02 & 30.98 \\
\hline $\begin{array}{l}\text { 12. Most people believe their friends would not visit them as often if a } \\
\text { member of their family were hospitalized for a serious mental illness }\end{array}$ & 68.48 & 31.52 \\
\hline $\begin{array}{l}\text { 13. Most people would not treat families with a member who is } \\
\text { mentally ill in the same way they treat other families }\end{array}$ & 59.24 & 40.76 \\
\hline $\begin{array}{l}\text { 14. Most people do blame parents for the mental illness of their } \\
\text { children }\end{array}$ & 74.46 & 25.54 \\
\hline $\begin{array}{l}\text { 15. Most people would rather not visit families that have a member } \\
\text { who is mentally ill }\end{array}$ & 71.20 & 28.80 \\
\hline Mean percentage of participants & 69.3 & 30.7 \\
\hline
\end{tabular}

Table 2: Patient's responses on statements of the DCFS ( $N=184)$.

\section{Self-esteem}

The Cronbach's alpha of the RSES was 0.89 indicating good reliability. Almost all participants (98\%) agreed with the statement "I feel that I have a number of good qualities". On the other hand, almost half of participants expressed (strong) agreement on the items "I wish I could have more respect for myself" and "I certainly feel useless at times".

\section{Linear regression analysis}

Results of linear regression analysis showed that in all models, self-esteem was significantly associated with SA (beta $=-0.37, \mathrm{p}<0.001$ in model 2 for DCS and beta $=-0.32$ in model 2 DCFS). More self-esteem was associated with less SA. Age was significantly associated with DCS-score (beta $=0.17, \mathrm{p}<0.001$ in model 2 DCS). Psychopathology was significantly associated with DCFS-score (beta = $0.21, \mathrm{p}=0.009$ in model 2), but not with DCS-score. In both models of DCS and DCFS there were no significant associations between SA and 1) gender, 2) illness duration, or 3 ) ethnicity. The explained variance, $\mathrm{R}^{2}$, ranged from 0.18 (model 1 
DCFS) to 0.22 (model 2 DCS), indicating that 18 to $22 \%$ of variance in SA was explained by the independent variables (Table 3).

\begin{tabular}{|c|c|c|c|c|}
\hline & \multicolumn{2}{|l|}{ DCS } & \multicolumn{2}{|l|}{$\overline{\text { DCFS }}$} \\
\hline & $\beta$ & $p$ & $\beta$ & $p$ \\
\hline Model 1 & \multicolumn{2}{|c|}{$R^{2}=0.21$} & \multicolumn{2}{|c|}{$R^{2}=0.18$} \\
\hline Self-esteem (RSES) & -0.41 & $<0.001^{*}$ & -0.39 & $<0.001^{\star}$ \\
\hline Gender & 0.05 & 0.481 & 0.05 & 0.483 \\
\hline Age & 0.16 & $0.039^{*}$ & 0.13 & 0.103 \\
\hline Illness duration & -0.03 & 0.701 & -0.15 & 0.064 \\
\hline Ethnicity & -0.01 & 0.934 & -0.03 & 0.660 \\
\hline Model 2 & \multicolumn{2}{|c|}{$R^{2}=0.22$} & \multicolumn{2}{|c|}{$R^{2}=0.21$} \\
\hline Self-esteem (RSES) & -0.37 & $<0.001^{*}$ & -0.32 & $<0.001^{*}$ \\
\hline Psychopathology (BPRS) & 0.12 & 0.133 & 0.21 & $0.009^{*}$ \\
\hline Gender & 0.07 & 0.324 & 0.11 & 0.145 \\
\hline$\overline{\text { Age }}$ & 0.17 & $0.029^{*}$ & 0.13 & 0.086 \\
\hline Illness duration & -0.03 & 0.738 & -0.13 & 0.088 \\
\hline Ethnicity & -0.02 & 0.763 & -0.06 & 0.413 \\
\hline
\end{tabular}

Table 3. Results of linear regression analyses on stereotype awareness (SA).

\section{Discussion}

This is, to our knowledge, the first study that shows an association between stereotype awareness about patients (DCS) and their families (DCFS) and selfesteem in people with psychotic disorder. Results show that decreased self-esteem is associated with increased awareness of stereotypes of patients and their family members. Furthermore, (severity of) psychopathology is associated with stereotypes about family members of patients with mental illness. This reflects that not only patients but also their families can be the subject of stereotyping and stigmatization, while the awareness of stereotypes concerning families is associated with psychopathology. A non-significant association between SA and severity of psychopathology in the same direction was found in SA concerning patients.

Being aware of stereotypes held by the public ("most people" in society) with respect to patients' families, may also be a source of distress. It may be an indicator of courtesy stigma (Goffman 1963); the process of being stigmatized by virtue of association with a stigmatized individual (Ostman and Kjellin 2002). When people with mental illness not only perceive stereotypes about patients but also about 


\section{Chapter 4}

families, stigma experiences may be even more pervasive for the individual. However, in the present study, patients disagreed (disagree/strongly disagree) with most of the statements on the DCFS, indicating that they did not perceive stereotypes about families of people with mental illness to be held by "most people" in society. Most participants perceived less stereotypes about family members of people with mental illness, than stereotypes about patients.

Patients agreed the most with item 4 ("Most people look down on someone who once was a patients in a mental hospital") and 6 ("Most people think less of a person who has been a patient in a mental hospital") of the DCS. According to Struening and colleagues (2001) these items indicate a judgmental reaction to consumers who have experienced hospitalization for mental illness, ascribing them a lower status position. These responses are considered put-downs or expressions of rejection or criticism (Struening, Perlick et al. 2001).

The study showed that higher self-esteem was associated with less SA. Positive self-esteem is not only seen as a basic feature of mental health, but also as a protective factor that contributes to better mental health and positive social behavior through its role as a buffer against the impact of negative cognitions, emotions and dysfunctional behavioral responses. Self-esteem represents a motivational force that influences perceptions and coping. In the context of negative messages and stressors, positive self-esteem can have various protective functions (Mann, Hosman et al. 2004). Protective factors interact with risk to modify its effects in a positive direction (Harrop, Addis et al. 2006).

In a model by Watson and coworkers (2007), SA is viewed as one of the components in the process of self-stigma. Other components are stereotype agreement - endorsing the same stereotypes perceived to be common in the public and self-concurrence - when people believe that culturally internalized beliefs in fact apply to them (Corrigan, Watson et al. 2006). In the present study, high selfesteem is viewed as a protective factor leading to resilience, while low self-esteem may be a vulnerability factor for the experience of stigma. Of course, no causal attributions are possible given the cross-sectional nature of the data.

Brohan and colleagues (2010) found that $42 \%$ of people with schizophrenia or other psychotic disorders experienced self-stigma in moderate to high levels. Dealing with SA may be a useful way to diminish self-stigma experiences of the 
individual. While SA can be viewed as an indicator of public stigma, people may over- or underestimate the stereotypes in the public.

A sense of self-worth and a belief that one can control one's destiny and life events, actual power, and righteous anger and community activism are important elements of empowerment (Rogers, Chamberlin et al. 1997). Rogers and colleagues (1997) indicate that programs aimed at promoting empowerment must focus on, for example, increasing self-esteem and self-efficacy, decreasing feelings of powerlessness, and increasing feelings of power. Stigma resilience and empowerment may be promoted in therapeutic and/or educational programs, in which experts by experience can play an important role. However, functional strategies to cope with stigma have to be applied in stigmatizing situations in everyday life. The social network of the individual is important in this respect. A limited social network may contribute to the vulnerability to internalize stigmatizing attitudes and to more strongly perceive devaluation and discrimination (Sibitz, Amering et al. 2011). Furthermore, individual as well as situational characteristics are important in the experience of stigma: The response to stigma, of an individual with mental illness, may consist of diminished self-esteem and self-efficacy, righteous anger and empowerment, or relative indifference, depending on the parameters of the situation (Watson and River 2005). Corrigan and Kleinlein (2005) state that persons with intact self-esteem will respond to stigma with indifference or indignation depending on their identification with the generic group of people with mental illness. Peterson and Barnes (2009) indicate: "If people with experience of mental illness are encouraged to empower themselves, their self-efficacy and self-esteem will increase, thus combating selfstigma".

\section{Limitations}

Data were derived from a cross-sectional survey. Therefore, self-esteem, psychopathology and SA were measured at the same moment, precluding conclusions about temporal relationships and causality. The results may be influenced by the fact that most participants (69\%) were male and participants reported relatively low levels of psychopathology (BPRS) in the two weeks before measurement. Moreover, people were diagnosed with a psychosis spectrum disorder, which limits our findings to this (broad) group of individuals. Also, 
perception of the respondent of "most people's" beliefs may be influenced by, for example, alterations in social cognition such as theory of mind.

\section{Practical implications}

Self-esteem and SA may be usefully targeted in anti-stigma interventions. This strategy may be of particular interest for people with early symptoms of psychosis. Targeted interventions at this stage may alter illness outcomes. Perceived stereotyping may exacerbate early psychopathology in the case of incipient illness, or increase the probability of relapse in case of established illness, for instance, by inducing a vicious circle of self-blame, attributing negative feedback to the self or by increasing stigma consciousness (van Zelst 2009). Thus, in the phase of early intervention, one of the factors that may prevent transition to more severe psychopathology is to increase resilience in subjects with a high level of awareness of stereotypes. Interventions can help people to deal with stigma, to increase selfesteem, and to become more stigma-resilient (van Zelst 2009).

Future research can inform us on SA, about people with mental illness and their families, in people with or without other mental health problems or diagnoses. It may also further inform us on associations with for example self-esteem and other protective factors, as well as psychopathology. Research on gender and stigmarelated factors (Farina 1981, Wirth and Bodenhausen 2009) can be elaborated to customize gender-specific interventions. Gender is a source of stereotyping in itself. Therefore, research on its direct and indirect effects on stigmatization in people with mental illness is required.

The consequences of stereotype threat (Steele and Aronson 1995) may be worse than SA, for example by increasing stress and interfering with daily life functioning. In future studies, it is important to include situational characteristics that can bring about stereotype threat in the flow of daily life, measured, for example, with the Experience Sampling Method (Csikszentmihalyi and Larson 1987, Delespaul 1995, Myin-Germeys, Oorschot et al. 2009).

\section{Conclusion}

Enhancing psychological resources, focusing on self-esteem and the ability to cope with symptoms, may be relevant targets to increase stigma resilience and empowerment. A higher level of self-esteem may be a protective factor, and coping 
with symptoms may reduce the consequences of stigma experience. SA may precede or co-occur with self-stigma and can be targeted in conjunction with other aims of treatment. Interventions can be tailored to individual differences to increase their effect. In tandem with the individual approach in patients, the public should be informed about mental illness and stigma, including the negative consequences of uncritical stereotyping.

Acknowledgments: We are grateful for the generosity of time and effort by the families who make the GROUP project possible. We also thank Wolfgang Viechtbauer for his help with statistical analyses.

The Genetic Risk and Outcome of Psychosis (GROUP) Investigators are: Richard Bruggeman, Wiepke Cahn, Lieuwe de Haan, René S. Kahn, Carin J. Meijer, Inez Myin-Germeys, Jim van Os en Durk Wiersma. 


\section{References}

Ajtony, Z. (2011). "Ethnic stereotypes - Impediments or enhancers of social cognition?" Acta Universitatis Sapientiae, Philologica 3(2): 134-155.

Angermeyer, M. C. and H. Matschinger (2004). "The stereotype of schizophrenia and its impact on discrimination against people with schizophrenia: results from a representative survey in Germany." Schizophr Bull 30(4): 1049-1061.

APA (2000). Diagnostic and Statistical Manual of Mental Disorders. Washington, American Psychiatric Association.

Biernat, M. and J. F. Dovidio (2000). Stigma and stereotypes. The social psychology of stigma. T. F. Heatherton, R. E. Kleck, M. R. Hebl and J. G. Hull. New York, The Guilford Press: $88-125$.

Brohan, E., R. Elgie, N. Sartorius and G. Thornicroft (2010). "Self-stigma, empowerment and perceived discrimination among people with schizophrenia in 14 European countries: the GAMIAN-Europe study." Schizophr Res 122(1-3): 232-238.

Corrigan, P. W. and P. Kleinlein (2005). The impact of mental illness stigma. On the stigma of mental illness. P. W. Corrigan. Washington, American Psychological Association: 11-44.

Corrigan, P. W. and P. Kleinlein (2005). The impact of mental illness stigma. On the stigma of mental illness: Practical strategies for research and social change. P. W. Corrigan. Washington, DC, American Psychological Association.

Corrigan, P. W., J. E. Larson and N. Rusch (2009). "Self-stigma and the "why try" effect: impact on life goals and evidence-based practices." World Psychiatry 8(2): 75-81.

Corrigan, P. W., T. J. Watson and L. Barr (2006). "The self-stigma of mental illness: implications for self-esteem and self-efficacy." J Soc Clin Psychol 25(9): 875-884.

Csikszentmihalyi, M. and R. Larson (1987). "Validity and reliability of the ExperienceSampling Method." J Nerv Ment Dis 175(9): 526-536.

Delespaul, P. A. E. G. (1995). Assessing schizophrenia in daily life. The Experience Sampling Method. Maastricht, Universitaire Pers Maastricht.

Delespaul, P. A. E. G., M. L. F. J. Bak and J. van Os (2008). Handleiding GGZ Monitor Zuid-Limburg 2008. Maastricht, Universiteit Maastricht.

Farina, A. (1981). "Are women nicer people than men? Sex and the stigma of mental disorders." Clin Psychol Rev 1: 223-243.

Goffman, E. (1963). Stigma: Notes on the Management of Spoiled Identity. Englewood Cliffs, NJ, Prentice-Hall.

Harrop, E., S. Addis, E. Elliott and G. Williams (2006). "Resilience, coping and salutogenic approaches to maintaining and generating health: A review.". 
Hayward, P. and J. A. Bright (1997). "Stigma and mental illness: A review and critique." J Ment Health 6(4): 345-354.

Link, B. G., F. T. Cullen, E. L. Struening, P. E. Shrout and B. P. Dohrenwend (1989). "A modified labeling theory approach in the area of mental disorders: an empirical assessment." Am Sociol Rev 54: 100-123.

Link, B. G., E. L. Struening, S. Neese-Todd, S. Asmussen and J. C. Phelan (2001). "Stigma as a barrier to recovery: The consequences of stigma for the self-esteem of people with mental illnesses." Psychiatr Serv 52(12): 1621-1626.

Mann, M., C. M. Hosman, H. P. Schaalma and N. K. de Vries (2004). "Self-esteem in a broad-spectrum approach for mental health promotion." Health Educ Res 19(4): 357-372.

Myin-Germeys, I., M. Oorschot, D. Collip, J. Lataster, P. Delespaul and J. van Os (2009). "Experience sampling research in psychopathology: opening the black box of daily life." Psychol Med 39(9): 1533-1547.

Ostman, M. and L. Kjellin (2002). "Stigma by association: psychological factors in relatives of people with mental illness." Br J Psychiatry 181: 494-498.

Overall, J. E. and D. R. Gorham (1962). "The Brief Psychiatric Rating Scale (BPRS)." Psychol Rep 10: 799-812.

Peterson, D. and A. Barnes (2009). What is self-stigma? Stepping out of the shadows: Insights into self-stigma and madness. D. Peterson and S. Gordon. Wellington, Case Consulting Ltd.

Rogers, E. S., J. Chamberlin, M. L. Ellison and T. Crean (1997). "A consumer-constructed scale to measure empowerment among users of mental health services." Psychiatr Serv 48(8): 1042-1047.

Rosenberg, M. (1965). Society and the adolescent self-image. Princeton, Princeton University Press.

Rusch, N., P. W. Corrigan, A. Wassel, P. Michaels, M. Olschewski, S. Wilkniss and K. Batia (2009). "A stress-coping model of mental illness stigma: I. Predictors of cognitive stress appraisal." Schizophr Res 110(1-3): 59-64.

Schneider, D. J. (2004). The psychology of stereotyping. New York, The Guilford Press.

Sibitz, I., M. Amering, A. Unger, M. E. Seyringer, A. Bachmann, B. Schrank, T. Benesch, B. Schulze and A. Woppmann (2011). "The impact of the social network, stigma and empowerment on the quality of life in patients with schizophrenia." Eur Psychiatry 26(1): 28-33.

StataCorp. (2009). "Stata Statistical Software: Release 11."

Steele, C. M. and J. Aronson (1995). "Stereotype threat and the intellectual test performance of African Americans." J Pers Soc Psychol 69(5): 797-811. 
Chapter 4

Struening, E. L., D. A. Perlick, B. G. Link, F. Hellman, D. Herman and J. A. Sirey (2001). "Stigma as a barrier to recovery: The extent to which caregivers believe most people devalue consumers and their families." Psychiatr Serv 52(12): 1633-1638.

van Zelst, C. (2009). "Stigmatization as an environmental risk in schizophrenia: a user perspective." Schizophr Bull 35(2): 293-296.

Ventura, J., D. Lukoff and K. H. Nuechterlein (1993). "Brief Psychiatric Rating Scale (BPRS) Expanded Version (4.0): Scales, Anchor Points and Administration Manual." Int J Methods Psychiatr Res 3: 227-244.

Watson, A. C., P. Corrigan, J. E. Larson and M. Sells (2007). "Self-stigma in people with mental illness." Schizophr Bull 33(6): 1312-1318.

Watson, A. C. and L. P. River (2005). A social-cognitive model of personal responses to stigma. On the stigma of mental Illness: Practical strategies for research and social change. P. W. Corrigan. Washington, DC, American Psychological Association.

Wirth, J. H. and G. V. Bodenhausen (2009). "The role of gender in mental-illness stigma: a national experiment." $\quad$ Psychol Sci 20(2): 169-173. 


\section{Chapter 5}

\section{Associations between stereotype awareness, childhood trauma and psychopathology: A study in people with psychosis, their siblings and controls}

Submitted as:

van Zelst, C., van Nierop, M., van Dam, D. S., Bartels-Velthuis, A. A., Delespaul, P., \& GROUP-investigators. Associations between stereotype awareness, childhood trauma and psychopathology: A study in people with psychosis, their siblings and controls. 


\title{
Chapter 5
}

\begin{abstract}
Introduction: Stereotype awareness - or an individual's perception of the degree to which negative beliefs or stereotypes are held by the public ("most people" in society) - is an important factor mediating public stigma, self-stigma and their negative consequences. Research is required to assess how individuals become more sensitive to perceive stereotypes that can lead to the experience of stigma, pointing the way to therapeutic options to reduce its effect. Because perception and interpretation can be guided by belief systems, and childhood trauma (CT) is reported to impact such beliefs, CT is explored in relation to stereotype awareness
\end{abstract} (SA) in persons with psychosis, their siblings and controls.

Method: Data from the GROUP-project (Genetic Risk and Outcome of Psychosis) were analyzed. SA was measured by devaluation scales which assess a respondent's perception of most other people's beliefs about people with a mental illness and about their families. CT was measured using the Childhood Trauma Questionnaire (short form).

Results: In patients, symptoms of disorganization and emotional distress were associated with SA about people with mental illness. In siblings, schizotypal features were associated with both types of SA (more schizotypy = more SA). In both patients and siblings, CT was associated with both types of SA (more CT = more SA).

Conclusion: CT in people with psychosis and their siblings may sensitize to SA. Thus, CT may not only impact on risk for illness onset, it can also increase SA associated with mental illness, potentially interfering with the recovery process. CT-induced SA may indicate a heightened sensitivity to threat, which may also impact psychopathology. 


\section{Introduction}

Experience of public stigma (not being accepted by society) and childhood trauma (CT) represent adversities, which can be part of the lives of people with psychosis. An important factor in the experience of stigma is one's awareness of stereotypes about patients and their families. Since stereotype awareness (SA) and CT may both influence beliefs about the self, exploring these factors can be useful to optimize interventions that increase resilience.

\section{Childhood trauma and psychosis}

A subgroup of people with psychosis has experienced CT. A meta-analysis by Varese and colleagues (2012) suggests a consistent association between childhood adversity or trauma and psychotic outcomes. They found adversity to be significantly associated with an increased risk for psychosis $(\mathrm{OR}=2.78)$. Heins and colleagues (2011) found that the association between CT and psychosis is apparent across vulnerable groups and people with different expression of illness, which suggests a true association rather than reporting bias, reverse causality, or passive gene-environment correlation (Heins, Simons et al. 2011).

CT has been found to impact negatively on symptomatic and functional outcomes in psychosis (Bendall, Alvarez-Jimenez et al. 2013). It may influence the formation of maladaptive schemas, which may lead to vulnerability to perceive stereotypes and experience stigma, which can lead to retraumatization.

\section{The experience of stigma, stereotype awareness and dysfunctional beliefs}

Although CT typically precedes onset of psychosis (Bak, Krabbendam et al. 2005, van Zelst 2008, Newman, Turnbull et al. 2010), and stigma is typically thought to develop after illness onset, stigma experiences may also occur before onset of psychosis, for example in the form of anticipated stigma (van Zelst 2008). Some people, having psychotic experiences or early psychotic symptoms, may expect stigma and discrimination, e.g. when talking about their experiences, while actual stigmatization after disclosure may or may not occur. Furthermore, anticipated stigma as well as other types of stigma can become more pronounced during and after illness onset. 


\section{Chapter 5}

Both CT and psychosis are linked to stereotypes, which in turn represent an important component in the development of stigma experiences (Link and Phelan 2001). Stereotypes or "qualities perceived to be associated with particular groups or categories of people" (Schneider 2004), play a role in both public stigma (indicating a negative belief about a group) and self-stigma (indicating a negative belief about the self) (Corrigan and Kleinlein 2005). Link and colleagues (Link, Cullen et al. 1989) described in their 'modified labeling theory' that perceptions of devaluation or discrimination are the first step in a labeling process that influences people when societal stereotypes (once labeled) are applied upon themselves (Link, Cullen et al. 1989). Corrigan, Watson \& Barr (2006) defined Link's process of perceived discrimination as stereotype awareness (SA): "the person is aware of the general negative beliefs about mental illness held by one's culture" (p.876). The experience of stigma may be either preceded by, or co-occur with, SA. Since beliefs about the self, others and the world are important in self-stigma, awareness of stereotypes may play an important role in this development. For example, it can influence the formation of dysfunctional beliefs. On the other hand, beliefs about the self, others and the world may also be influenced by trauma in childhood. Social marginalization, difficult or traumatic experiences or unsupportive family environments can contribute to the development of maladaptive schemas of the self and the world (Garety, Kuipers et al. 2001). CT increases vulnerability, possibly through the mechanisms of SA that results in depreciating beliefs about self and others (e.g. "I am worthless" or "Others will reject me").

To our knowledge, research combining CT, stigma and psychosis is scarce. In one study, the relationships between trauma history, trait anger and stigma were examined (Outcalt and Lysaker 2012). Outcalt and Lysaker report that stigma experiences can be affected by past experiences of sexual trauma in people with a diagnosis of schizophrenia (Outcalt and Lysaker 2012). Comparison of groups with and without a history of sexual trauma revealed that those who experienced sexual trauma reported more discrimination experience, alienation, and social withdrawal five months later. These results suggest that trauma history may lead to an increased vulnerability to stigmatizing beliefs.

More knowledge about determinants of SA may improve treatment and educational interventions aimed at reducing negative consequences of stigma, in patients, family members and possibly others in the broad society. 
The present study explores whether SA and CT are associated, possibly indicating that CT may sensitize individuals for SA and stigma experiences. We hypothesized that CT may increase the salience for negative stereotypes in the public. Therefore CT may be associated with SA (more $\mathrm{CT}=$ more $\mathrm{SA}$ ).

Because patients and siblings may share a cultural similarity about stereotypes, and may to a certain degree be exposed to the same trauma-prone and psychosisinducing environments, we studied the link between CT and SA in people with psychosis and in their siblings. A sample of healthy controls was used as a reference group. In a previous study (van Zelst, van Nierop et al. 2014) stereotype awareness was found to be associated with psychopathology in patients with psychosis. Psychopathology was therefore included as a covariate in the analyses.

\section{Methods}

Data pertain to the first and second interview wave of the Genetic Risk and Outcome of Psychosis (GROUP) study, an ongoing longitudinal multicenter study in Europe (Korver, Quee et al. 2012). In selected representative geographical areas of the Netherlands and (the Dutch speaking part of) Belgium, patients were identified through clinicians working in regional psychosis care facilities or academic centers. Eligible patients presenting consecutively at these services either as outpatients or inpatients were recruited for the study. Their siblings were contacted. Controls were selected through a system of random mailings to addresses in the catchment areas of the cases. For a detailed description of objectives, sample characteristics, recruitment and assessment methods, see the paper by Korver and colleagues (2012).

\section{Ethics statement}

Persons identified as potentially eligible and deemed capable of providing informed consent by their clinician were given detailed explanation of the study procedures and were asked for written informed consent for detailed assessment and for contacting their first-degree family members (brothers, sisters, parents). Written informed consent was also obtained from the next of kin, caretakers, or guardians of those aged 16-17 years. Before written informed consent was obtained, persons had the opportunity to reflect on and ask questions about participation. They could talk about the study with an independent physician who 


\section{Chapter 5}

was not involved in the study. All potential participants who declined to participate or otherwise did not participate were eligible for treatment (if applicable) and were not disadvantaged in any way in case of non-participation. The study protocol was approved by the Ethical Review Board of the University Medical Centre Utrecht.

\section{Subjects}

Inclusion criteria were: age range of 16-50 years at baseline, good command of the Dutch language, able and willing to give written informed consent and, in patients, a clinical diagnosis of non-affective psychotic disorder according to the Diagnostic and Statistical Manual of Mental Disorders, fourth edition (DSM-IV) (APA 2000). Furthermore, controls did not have a lifetime psychotic disorder or a first-degree family member with a lifetime psychotic disorder (Korver, Quee et al. 2012). Only subjects who filled in more than $70 \%$ of the items of the SA-scales (see "scales") were included.

\section{Scales}

\section{Dependent variable}

Stereotype awareness was measured using the Devaluation of Consumers Scale (DCS, 8 items) and the Devaluation of Consumers Families Scale (DCFS, 7 items) (Struening, Perlick et al. 2001). These scales assess a respondent's perception of what most other people believe about patients with a mental illness (DCS) and their families (DCFS). All items are rated on 4-point Likert Scales: Strongly disagree $(=1)$, Disagree, Agree, Strongly agree $(=4)$. In the statistical analyses, the average item scores were used as overall scores. The higher the score on the DCS or DCFS, the more a person is aware of the general negative beliefs about mental illness held by one's culture.

Struening and colleagues (2001) reported an internal consistency reliability coefficient of 0.82 for the DCS in two samples of caregivers, and coefficients of 0.71 and 0.77 for the DCFS in these samples. Another study into caregivers' perception of stigma reported a Cronbach's $\alpha$ for the DCFS of 0.80 (Perlick, Miklowitz et al. 2007). 
Independent variables

Childhood trauma was assessed with Dutch version of the 25-item Childhood Trauma Questionnaire - Short Form (Bernstein, Stein et al. 2003). Items are rated on 5-point Likert scales ( $1=$ never true, $5=$ very often true). The scale rates sexual abuse (sexual contact or conduct between a child and an adult or older person), physical abuse (bodily assaults that posed a risk or resulted in injury), emotional abuse (verbal assaults on a child's sense of worth or well-being or any humiliating or demeaning behavior directed toward a child by an adult or older person), physical neglect (the failure of caretakers to provide basic physical needs) and emotional neglect (the failure to meet the child's basic emotional and psychological needs). The CTQ-SF has adequate reliability and content coverage (Bernstein, Stein et al. 2003). In the statistical analyses, the individual's CTQ-SF score was used, representing the mean of the overall scores of the five clusters (sexual, physical and emotional abuse, and physical and emotional neglect).

Psychopathology was assessed using the Positive and Negative Syndrome Scale (PANSS) (Kay, Fiszbein et al. 1987), which measured symptom intensity in the two weeks before the interview. Items are rated on a 7-point ordinal scale. For the purpose of the analyses, data were summarized using an empirical model with five factors: positive symptoms, negative symptoms, disorganization, excitement and emotional distress (van der Gaag, Hoffman et al. 2006). Psychotic experiences display a dimensional distribution in the general population (Ahmed, Buckley et al. 2012). Since the PANSS is not sensitive in subjects without psychotic disorder (controls and siblings), we assessed "schizotypy" in these groups with the Structured Interview for Schizotypy - Revised (SIS-R). The SIS-R was developed for assessing subtle schizotypal features in non-psychotic relatives of schizophrenia patients (Vollema and Ormel 2000), indexing the psychometric expression of vulnerability for psychotic disorder. For the current analysis, the overall score of the SIS-R was used.

\section{Statistical analyses}

Analyses were done on data release 3.02 of the GROUP study. Since the CTQ-SF was administered during the first wave in region Maastricht and during the second wave in the regions Amsterdam, Groningen and Utrecht, we used data of both waves. Eligible patients were identified in three subsamples (patients, siblings, 


\section{Chapter 5}

controls). Statistical analyses were done with STATA 11.2 (StataCorp. 2009). Data were analyzed using multilevel linear (ML) regression models with family (nesting variable for patients and siblings) as grouping variable. The ML regression analyses were computed with stereotype awareness (DCS or DCFS) as dependent variable. In the first model, we analyzed the association between SA (DCS or DCFS) and CT (CTQ-SF). "Patients" and "siblings" were added as dummy variables indicating patients or siblings group respectively. Controls served as reference category. Interactions of "patients" and CT and "siblings" and CT were added, and gender, age and ethnicity $(0=$ white, $1=$ non-white $)$ were included as $a$ priori covariates. In further analyses, we studied the association between psychopathology (PANSS factor scores in patients and SIS-R scores in siblings and controls) and SA. As the impact of CT on SA will likely differ as a function of illness (patient) and/or vulnerability for illness (siblings), interactions between CT and GROUP were added in the models of SA.

\section{Results}

\section{Subjects}

641 patients completed the DCS and 638 the DCFS. These summary scores were moderately correlated $(\mathrm{r}=0.58) .707$ siblings completed the DCS and 704 the DCFS (correlation $\mathrm{r}=0.62$ ). 415 controls completed the DCS and 413 the DCFS (correlation $\mathrm{r}=0.63$ ) (Table 1). Comparing mean scores of patients, siblings and controls with oneway-ANOVA revealed that the three groups did not differ in SA about patients (DCS: $F=2.69, p=0.0682$ ), whereas they did differ in the mean SA about families (DCFS: $F=13.39 ; \mathrm{p}=0.000$ ). Table 1 summarizes demographics, psychopathology and SA scores. 

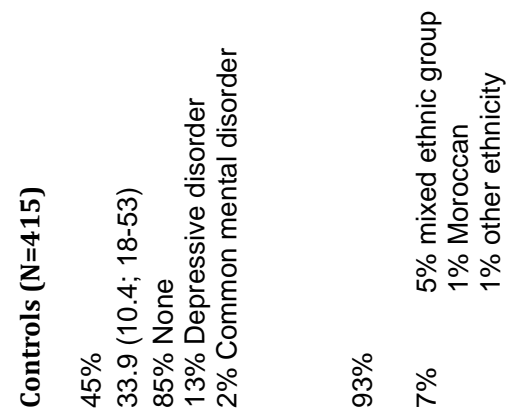

ஓें ฉ̊
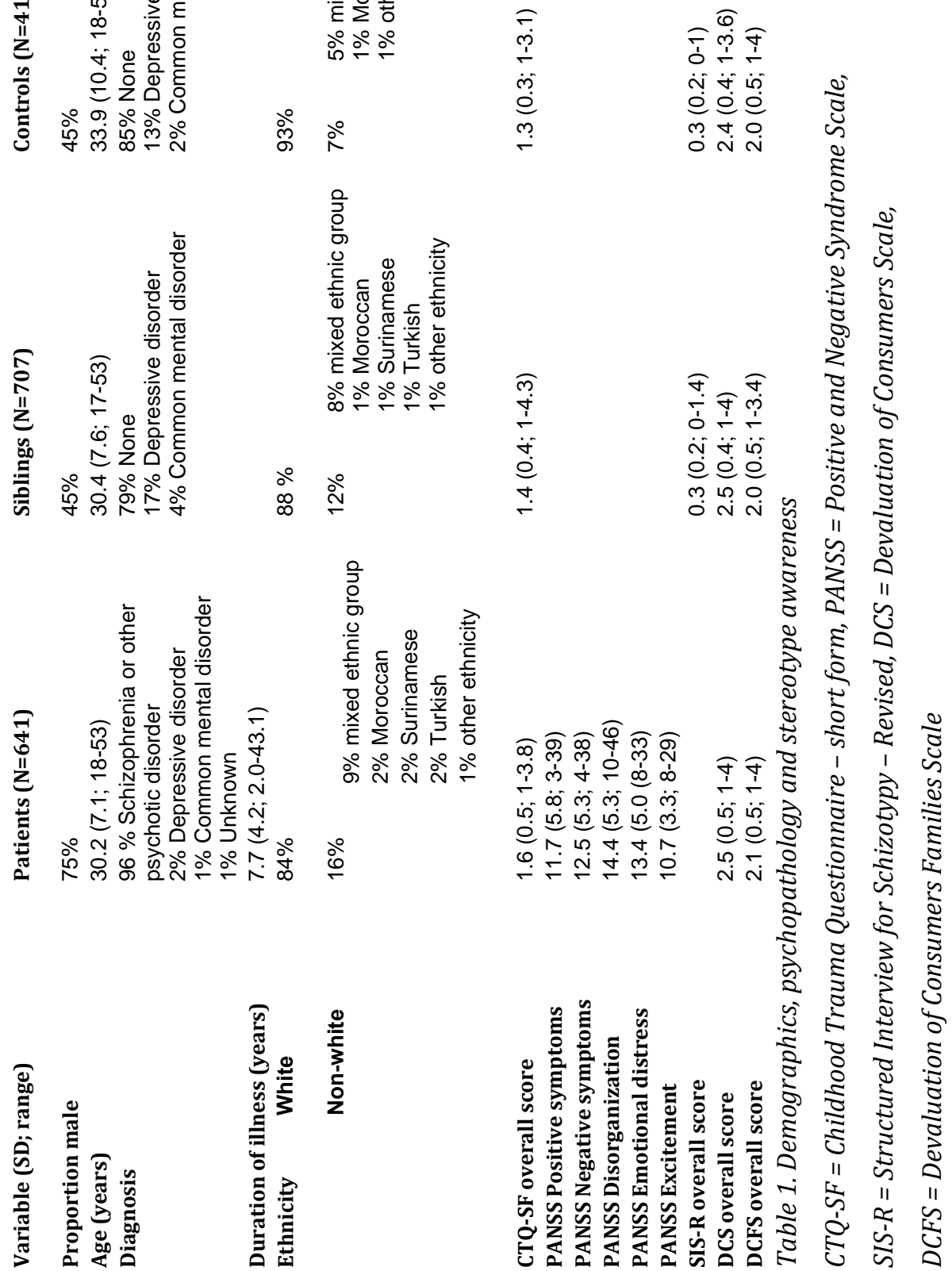



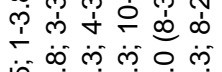

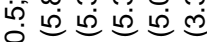

e 5 , d t

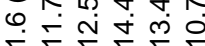

唡 ำ



ฮั 


\section{Chapter 5}

\section{Childhood trauma and stereotype awareness}

All regression models were adjusted for gender, age and ethnicity. In the first model (Table 2), group membership was associated with DCS, siblings and patients scoring higher than controls, as well as with DCFS, siblings scoring higher than controls. There was no association between CT and SA, but in this model a significant interaction between group and CT was apparent. Figure 1 and 2 show associations between CT and DCS for these first two models.

\begin{tabular}{|l|l|l|l|l|}
\hline & \multicolumn{2}{|l|}{ DCS } & DCFS \\
\hline & $\boldsymbol{\beta}$ & $\mathbf{p}$ & $\boldsymbol{\beta}$ & $\mathbf{p}$ \\
\hline Group siblings & -0.29 & $0.015^{\star}$ & -0.30 & $0.012^{*}$ \\
\hline Group patients & -0.25 & $0.032^{\star}$ & -0.14 & 0.219 \\
\hline CTQ-SF & 0.00 & 0.991 & 0.08 & 0.229 \\
\hline Group siblings * CTQ-SF & 0.37 & $0.004^{\star}$ & 0.28 & $0.026^{*}$ \\
\hline Group patients * CTQ-SF & 0.33 & $0.020^{*}$ & 0.25 & 0.074 \\
\hline
\end{tabular}

Table 2. Results of multilevel regression analysis on stereotype awareness in patients, siblings and controls (reference category).

Results adjusted for gender, age and ethnicity

CTQ-SF = Childhood Trauma Questionnaire - short form, DCS = Devaluation of Consumers Scale, DCFS = Devaluation of Consumers Families Scale 




Figure 1. Childhood trauma (CTQ-SF) and stereotype awareness (DCS) in patients, siblings and controls.

Example: Results for 30-year-old men of white ethnicity

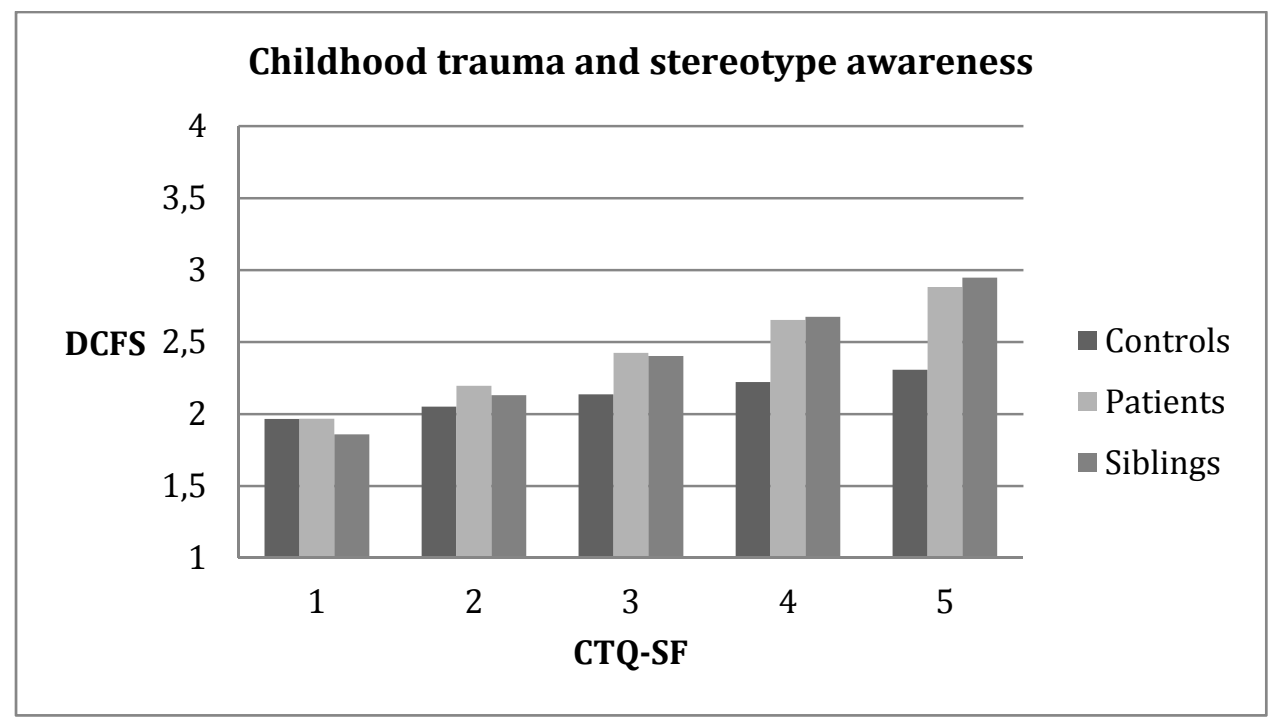

Figure 2. Childhood trauma (CTQ-SF) and stereotype awareness (DCFS) in patients, siblings and controls.

Example: Results for 30-year-old men of white ethnicity 


\section{Chapter 5}

Given significant interaction, stratified analyses were conducted for each group. In the patients, there was a positive association between CT and SA for both DCS and DCFS (more CT = more SA). Furthermore, two PANSS factors were associated with DCS (not DCFS): PANSS disorganization and PANSS emotional distress. PANSS disorganization was negatively associated with DCS and PANSS emotional distress positively (Table 3).

In the siblings, there was a positive association between CT and SA (both DCS and DCFS). SIS-R overall score was also significantly associated with SA (more SIS-R symptoms, more SA (both DCS and DCFS) (Table 4).

Models including both CT and SIS-R overall score as independent variables were not significant for controls. However, elimination of CT from the model revealed a significant positive association between SIS-R overall score and SA (in the DCS as well as the DCFS model).

\begin{tabular}{|l|l|l|l|l|}
\hline Patients & \multicolumn{2}{|l|}{ DCS } & DCFS \\
\hline & $\boldsymbol{\beta}$ & $\mathbf{p}$ & $\boldsymbol{\beta}$ & $\mathbf{p}$ \\
\hline CTQ-SF & 0.17 & $<0.001^{*}$ & 0.19 & $<0.001^{*}$ \\
\hline PANSS Positive symptoms & 0.05 & 0.487 & -0.01 & 0.895 \\
\hline PANSS Negative symptoms & 0.04 & 0.379 & 0.08 & 0.093 \\
\hline PANSS Disorganization & -0.15 & $0.011^{*}$ & -0.03 & 0.571 \\
\hline PANSS Emotional distress & 0.14 & $0.017^{*}$ & 0.11 & 0.070 \\
\hline PANSS Excitement & 0.08 & 0.182 & 0.06 & 0.291 \\
\hline
\end{tabular}

Table 3. Results of multilevel linear regression analysis on stereotype awareness in patients.

Results adjusted for gender, age and ethnicity

DCS = Devaluation of Consumers Scale; DCFS = Devaluation of Consumers Families Scale; CTQ-SF = Childhood Trauma Questionnaire - short form; PANSS = Positive and Negative Syndrome Scale 


\begin{tabular}{|l|l|l|l|l|}
\hline Siblings & \multicolumn{2}{|l|}{ DCS } & \multicolumn{2}{l|}{ DCFS } \\
\hline & $\boldsymbol{\beta}$ & $\mathbf{p}$ & $\boldsymbol{\beta}$ & $\mathbf{p}$ \\
\hline CTQ-SF & 0.16 & $<0.001^{*}$ & 0.16 & $<0.001^{*}$ \\
\hline SIS-R overall & 0.13 & $0.001^{\star}$ & 0.21 & $<0.001^{\star}$ \\
\hline
\end{tabular}

Table 4: Results of multilevel linear regression analyses on stereotype awareness in siblings.

Results adjusted for gender, age and ethnicity

DCS = Devaluation of Consumers Scale; DCFS = Devaluation of Consumers Families Scale; CTQ-SF = Childhood Trauma Questionnaire - short form; SIS-R = Structured Interview for Schizotypy - Revised

\section{Discussion}

The aim of this study was to explore SA, a factor representing stigma vulnerability, which can precede or co-occur with self-stigma, and assess its relation to childhood trauma (CT). In both patients and their siblings, CT was associated significantly with the awareness of stereotypes about patients and their families (SA). In patients, SA was also associated with symptoms of disorganization and emotional distress (for the DCS scale). In siblings, SA was additionally associated with schizotypal features. In controls, an association was found between schizotypal features and SA, but not between CT and SA.

Being aware of stereotypes is a prerequisite to experience stigma, and CT experiences may bring about sensitization to SA. For treatment and psychoeducational purposes, it would be helpful to know how CT is linked to SA.

People with a history of trauma may find it difficult to accurately appraise the self and the world. Many reports have documented how trauma reshapes the selfperception of the survivor, resulting in decreased self-esteem, shame, stigma, and guilt (Fallot and Harris 2002). A potential underlying mechanism mediating the impact of trauma and leading to negative and stigmatizing beliefs about the self, is that traumatized persons can be prone to unconsciously scanning the environment for threat (Pineles, Shipherd et al. 2007), which may serve as a confirmation of negative self-beliefs (Outcalt and Lysaker 2012). This may represent a bias resulting from rejection sensitivity. Another mechanism representing such bias concerns difficulty disengaging from trauma (Pineles, Shipherd et al. 2009). 


\section{Chapter 5}

People differ in their readiness to perceive and react to rejection (Downey and Feldman 1996). Rejection sensitivity develops through repeated and prolonged experiences of rejection. This sensitivity results in altered perception and behavior in situations where rejection is imminent. Rejection sensitivity is assumed to become a trait characteristic of the individual, but it is more strongly activated in 'threatening' situations and therefore also state dependent (Rosenbach and Renneberg 2011).

Sensitization of an individual to detect stereotypes may trigger the whole range of pathological biases, for example "negative underlying assumptions" (NUA's) (Beck 1979, Platt and Freyd 2012). The development of negative underlying assumptions about, for example, performance evaluation and approval by others after experiencing trauma may result in negative feelings such as shame. A study in undergraduate students indicated that individuals who are able to maintain low levels of negative underlying assumptions after trauma may be resilient to the potentially shaming effects of negative feedback (Platt and Freyd 2012). A low level of NUAs may be accompanied by stigma resilience as well. Additionally, high group value, when people with mental illness hold their group in high regard, and low perceived legitimacy of discrimination, when people reject stigma as unfair, may contribute to resilience to stigma (Rusch, Corrigan et al. 2009).

CT may induce behavioral sensitization to adult stress in individuals with increased psychosis liability (Lardinois, Lataster et al. 2011). In this sensitization process people may become, by previous exposure to adversity or stress, more sensitive or responsive rather than more resistant to the later occurrence of stress (Collip, Myin-Germeys et al. 2008, Lardinois, Lataster et al. 2011).

In siblings, both stigma directed at people with mental illness as well as stigma directed at their families can be a source of distress. Patients and their siblings may have shared experiences of psychopathology and stigma, associated with earlier environmental exposures that cluster in the family.

\section{Interventions}

Building and reinforcing resilience is important. By remediating the consequences of both stigma and CT, underlying beliefs about the self, others and the world can be addressed. However, stigma about mental health problems should also be addressed in society as a whole. People may experience stigma before onset of 
disorder or diagnosis (van Zelst 2008). Consequently, both CT and anticipated stigma may delay help-seeking, which can increase the risk of a worse course of psychosis. Early detection of mental health complaints, a focus that incorporates (anticipated) stigma experiences, may thus be useful. Normalizing mental health complaints can therefore be an aim in mental health campaigns.

In a qualitative study by Kranke and colleagues (2011), adolescents indicated in their narratives that statements about people with mental illness were often similar to ideas that they heard from family, peers or the popular media. Educational interventions in schools may decrease stigma experiences of adolescents with mental health complaints.

Youths have limited life experience with integration and identity formation, and because self-stigma affects core identity processes - attitudes and beliefs about the self - it is likely that, compared with adults, adolescents have a less consolidated identity to protect against, buffer, or neutralize stereotypes and prejudice (Kranke, Floersch et al. 2011). Therefore, stigma management should be part of the psychological interventions from the very onset of psychotic experiences and relevant for clinical and educational practice.

In order to enhance resilience, professionals must carefully establish vulnerabilities and protective factors and then decide the best course of action to improve resilience (Iwaniec, Larkin et al. 2006).

Harvey (1996) describes a useful ecological model of psychological trauma and trauma recovery. An ecological model highlights, in acknowledging the multidimensional nature of trauma recovery and the possibility of recovery in the absence of clinical intervention, the construct of resilience, the role of the wider social environment, the contributions of natural supports, and the relevance of community interventions to alter discriminating beliefs (Harvey 1996).

\section{Limitations}

Although this study shows a relationship between CT and SA, it does not inform us on the consequences of SA for the individual. Further research may reveal which factors contribute to stigma resilience and which factors heighten the negative impact of SA. People with psychosis can also experience trauma in other stages of life. Further research may inform us on whether and to what extent our findings can be generalized to re-victimization in adulthood and to what extent overcoming 
Chapter 5

traumatic experiences may contribute to empowerment. Psychosis in itself is often considered a traumatic experience, and ways to cope with this type of trauma should be addressed in future interventions.

Acknowledgements: We are grateful for the generosity of time and effort by the families who make the GROUP project possible. The Genetic Risk and Outcome of Psychosis (GROUP) Investigators are: Richard Bruggeman, Wiepke Cahn, Lieuwe de Haan, René S. Kahn, Carin J. Meijer, Inez Myin-Germeys, Jim van Os en Durk Wiersma. 


\section{References}

Ahmed, A. O., P. F. Buckley and P. A. Mabe (2012). "Latent structure of psychotic experiences in the general population." Acta Psychiatr Scand 125(1): 54-65.

APA (2000). Diagnostic and Statistical Manual of Mental Disorders. Washington, American Psychiatric Association.

Bak, M., L. Krabbendam, I. Janssen, R. de Graaf, W. Vollebergh and J. van Os (2005). "Early trauma may increase the risk for psychotic experiences by impacting on emotional response and perception of control." Acta Psychiatr Scand 112(5): 360366.

Beck, A. T. (1979). Cognitive therapy of depression. New York, Guilford Press.

Bendall, S., M. Alvarez-Jimenez, B. Nelson and P. McGorry (2013). "Childhood trauma and psychosis: new perspectives on aetiology and treatment." Early Interv Psychiatry 7(1): 1-4.

Bernstein, D. P., J. A. Stein, M. D. Newcomb, E. Walker, D. Pogge, T. Ahluvalia, J. Stokes, L. Handelsman, M. Medrano, D. Desmond and W. Zule (2003). "Development and validation of a brief screening version of the Childhood Trauma Questionnaire." Child Abuse Negl 27(2): 169-190.

Collip, D., I. Myin-Germeys and J. Van Os (2008). "Does the concept of "sensitization" provide a plausible mechanism for the putative link between the environment and schizophrenia?" Schizophr Bull 34(2): 220-225.

Corrigan, P. W. and P. Kleinlein (2005). The impact of mental illness stigma. On the stigma of mental illness. P. W. Corrigan. Washington, American Psychological Association: 11-44.

Corrigan, P. W., T. J. Watson and L. Barr (2006). "The self-stigma of mental illness: implications for self-esteem and self-efficacy." J Soc Clin Psychol 25(9): 875-884.

Downey, G. and S. I. Feldman (1996). "Implications of rejection sensitivity for intimate relationships." J Pers Soc Psychol 70(6): 1327-1343.

Fallot, R. D. and M. Harris (2002). "The Trauma Recovery and Empowerment Model (TREM): conceptual and practical issues in a group intervention for women." Community Ment Health J 38(6): 475-485.

Garety, P. A., E. Kuipers, D. Fowler, D. Freeman and P. E. Bebbington (2001). "A cognitive model of the positive symptoms of psychosis." Psychol Med 31(2): 189195.

Harvey, M. R. (1996). "An ecological view of psychological trauma and trauma recovery." J Trauma Stress 9(1): 3-23. 


\section{Chapter 5}

Heins, M., C. Simons, T. Lataster, S. Pfeifer, D. Versmissen, M. Lardinois, M. Marcelis, P. Delespaul, L. Krabbendam, J. van Os and I. Myin-Germeys (2011). "Childhood trauma and psychosis: a case-control and case-sibling comparison across different levels of genetic liability, psychopathology, and type of trauma." Am J Psychiatry 168(12): 1286-1294.

Iwaniec, D., E. Larkin and S. Higgins (2006). "Research review: Risk and resilience in cases of emotional abuse." Child and Family Social Work 11: 73-82.

Kay, S. R., A. Fiszbein and L. A. Opler (1987). "The positive and negative syndrome scale (PANSS) for schizophrenia." Schizophr Bull 13(2): 261-276.

Korver, N., P. J. Quee, H. B. Boos, C. J. Simons and L. de Haan (2012). "Genetic Risk and Outcome of Psychosis (GROUP), a multi-site longitudinal cohort study focused on gene-environment interaction: objectives, sample characteristics, recruitment and assessment methods." Int J Methods Psychiatr Res 21(3): 205-221.

Kranke, D. A., J. Floersch, B. O. Kranke and M. R. Munson (2011). "A qualitative investigation of self-stigma among adolescents taking psychiatric medication." Psychiatr Serv 62(8): 893-899.

Lardinois, M., T. Lataster, R. Mengelers, J. Van Os and I. Myin-Germeys (2011).

"Childhood trauma and increased stress sensitivity in psychosis." Acta psychiatr Scand 123(1): 28-35.

Link, B. G., F. T. Cullen, E. L. Struening, P. E. Shrout and B. P. Dohrenwend (1989). "A modified labeling theory approach in the area of mental disorders: an empirical assessment." Am Sociol Rev 54: 100-123.

Link, B. G. and J. C. Phelan (2001). "Conceptualizing stigma." Annu Rev Sociol 27: 363 385.

Newman, J. M., A. Turnbull, B. A. Berman, S. Rodrigues and M. R. Serper (2010). "Impact of traumatic and violent victimization experiences in individuals with schizophrenia and schizoaffective disorder." J Nerv Ment Dis 198(10): 708-714.

Outcalt, S. D. and P. H. Lysaker (2012). "The relationships between trauma history, trait anger, and stigma in persons diagnosed with schizophrenia spectrum disorders." Psychosis 4(1): 32-41.

Perlick, D. A., D. J. Miklowitz, B. G. Link, E. Struening, R. Kaczynski, J. Gonzalez, L. N. Manning, N. Wolff and R. A. Rosenheck (2007). "Perceived stigma and depression among caregivers of patients with bipolar disorder." $\mathrm{Br}$ J Psychiatry 190: $535-536$.

Pineles, S. L., J. C. Shipherd, S. M. Mostoufi, S. M. Abramovitz and I. Yovel (2009).

"Attentional biases in PTSD: More evidence for interference." Behav Res Ther 47(12): 1050-1057. 
Pineles, S. L., J. C. Shipherd, L. P. Welch and I. Yovel (2007). "The role of attentional biases in PTSD: is it interference or facilitation?" Behav Res Ther 45(8): 1903 1913.

Platt, M. and J. Freyd (2012). "Trauma and negative underlying assumptions in feelings of shame: an exploratory study." Psychol Trauma 4(4): 370-378.

Rosenbach, C. and B. Renneberg (2011). "Rejected, Excluded, Ignored: The Perception of Social Rejection and Mental Disorders: A review." English version of Verhaltenstherapie 21: 87-97.

Rusch, N., P. W. Corrigan, A. Wassel, P. Michaels, M. Olschewski, S. Wilkniss and K. Batia (2009). "Ingroup perception and responses to stigma among persons with mental illness." Acta Psychiatr Scand 120(4): 320-328.

Schneider, D. J. (2004). The psychology of stereotyping. New York, The Guilford Press. StataCorp. (2009). "Stata Statistical Software: Release 11."

Struening, E. L., D. A. Perlick, B. G. Link, F. Hellman, D. Herman and J. A. Sirey (2001). "Stigma as a barrier to recovery: The extent to which caregivers believe most people devalue consumers and their families." Psychiatr Serv 52(12): 1633-1638.

van der Gaag, M., T. Hoffman, M. Remijsen, R. Hijman, L. de Haan, B. van Meijel, P. N. van Harten, L. Valmaggia, M. de Hert, A. Cuijpers and D. Wiersma (2006). "The five-factor model of the Positive and Negative Syndrome Scale II: a ten-fold crossvalidation of a revised model." Schizophr Res 85(1-3): 280-287.

van Zelst, C. (2008). "Which environments for G x E? A user perspective on the roles of trauma and structural discrimination in the onset and course of schizophrenia." Schizophr Bull 34(6): 1106-1110.

van Zelst, C., M. van Nierop, M. Oorschot, I. Myin-Germeys, J. van Os, P. Delespaul and Group (2014). "Stereotype awareness, self-esteem and psychopathology in people with psychosis." PLoS One 9(2): e88586.

Varese, F., F. Smeets, M. Drukker, R. Lieverse, T. Lataster, W. Viechtbauer, J. Read, J. van Os and R. P. Bentall (2012). "Childhood adversities increase the risk of psychosis: a meta-analysis of patient-control, prospective- and cross-sectional cohort studies." Schizophr Bull 38(4): 661-671.

Vollema, M. G. and J. Ormel (2000). "The reliability of the structured interview for schizotypy-revised." $\quad$ Schizophr Bull $\quad$ 26(3): $\quad$ 619-629. 



\section{Chapter 6: General discussion}

Onset, course and outcome of psychosis are determined by interactions between genetic and environmental factors. Stigmatization is a significant adversity for individuals, groups and the broad society. Stigma is described as an important environmental factor that has negative consequences in multiple areas of daily life for people with psychosis (van Zelst, 2009) and (severe) mental illness in general (P.W. Corrigan \& Kleinlein, 2005). People with psychosis are frequently stigmatized and previous traumatization leaves them even more vulnerable to the effects of stigma. Psychotic symptoms can be distressing, but stigma can result in secondary traumatization that further hinders recovery. Public or social stigma is best known. It comprises negative reactions of society to an individual or group. Stigma attached to psychosis spectrum disorder persists even when individuals are symptom-free or recovered. (Jenkins \& Carpenter-Song, 2008). The hostile social response to those perceived as mentally ill is not related to behaviors, cognitions or moods, that are difficult to assess, but to the whole individual. The process of internalizing stereotypes and devaluing oneself is called self-stigma or internalized stigma. In this dissertation, it is argued that various types of stigma impact negatively on onset, course and outcome of psychosis. Furthermore, we focus on research into stereotype awareness, which is considered as an important element of stigma processes.

In the first part of this dissertation, I review the evidence on stigma and childhood trauma as etiological environmental factors for developing a psychosis. Chapter 1 stresses the importance of trauma and stigma (structural discrimination) as environmental factors in gene-environment-interactions in psychosis spectrum disorder. It covers the evidence on trauma during childhood or adulthood as a risk for individuals vulnerable to developing psychosis. Trauma may not only influence individuals before a first episode of psychosis. Psychotic experiences themselves and the effect of treatment and societal rejection may be traumatizing as well (retraumatization). The chapter assesses the different types of stigma and its possible consequences. Following Corrigan and Wassel (2008) a distinction is made between public stigma, self-stigma and label avoidance. Stigma can have an impact on the course and possibly also on the onset of psychosis spectrum disorder. 


\section{Chapter 6}

The vulnerability-stress-coping model, and self-fulfilling prophecies are mechanisms through which stigma can influence onset and course of the disorder. These can be initiated by both perceiver and target of public stigma (Jussim, Palumbo, Chatman, Madon, \& Smith, 2000). The beliefs and expectations held by potentially stigmatized persons themselves may lead to self-fulfilling prophecies. This is because the individual's beliefs that other persons stigmatize them, even when these beliefs are erroneous, may lead them to initiate an interaction process in which they ultimately fulfill the stereotypic expectations associated with their stigma (Jussim et al., 2000).

Not everybody with mental illness has experienced trauma or stigma. Nevertheless, this social adversity can influence the onset, course and outcome in a subgroup of people with psychotic experiences. It can therefore be an important focus of interventions that intend to build resilience through coping. Lazarus \& Folkman (1984) define coping as "constantly changing cognitive and behavioral efforts to manage specific external and/or internal demands that are appraised as taxing or exceeding the resources of the person". Stress is a personal experience that occurs when events pose a threat that could exceed the person's resources for coping (Lazarus \& Folkman, 1984). Psychological stress is contextualized. For stress to occur, the subject has to judge or cognitively appraise the situation (Lazarus \& Folkman, 1984). Stigma and its negative consequences are stressors. The individual who perceives stigma formulates a response that can match or fails to match the environmental challenge. While individuals develop their own coping strategies and can learn from peers, others - in or outside mental health care - may assist them in coping with trauma and stigma where needed.

Chapter 2 conceptualizes stigmatization as a modifiable environmental risk factor that exerts its influence along a variety of different pathways. This process may not just take place after the illness is formally diagnosed but also before, on the basis of subtle behavioral expressions of the schizophrenia liability. The model presented in this chapter takes stigma induced by expression of both illness and behavioral alterations associated with illness liability into account. When behavior is perceived as deviant, stigma may occur. This paper also mentions some other important mechanisms through which stigma can influence course of the disorder, such as via exacerbating symptoms, and by label avoidance which can cause a delay in help- or treatment seeking behavior. 
Chapter 3 views trauma and stigma as two environmental risk factors which have a cumulative 'defeating' effect on the individual over the life course and may interact with genetic vulnerability to influence onset and outcome of psychotic symptoms. Interventions focusing on education and building 'salutogenic' resources (e.g. skills) may prove useful in breaking the defeating cycle induced by adversity related to trauma and stigma. In these, personal resources including functional coping strategies can be addressed. Differential sensitivity to the psychotogenic effects of environmental risk factors is important to acknowledge both in research and clinical care. The chapter incorporates a perspective of salutogenesis. This theory gives a generic understanding of how sense of coherence (the central concept in salutogenesis) and coping may be created, and focuses on pathways that lead to successful coping and health (Langeland, Wahl, Kristoffersen, \& Hanestad, 2007).

The second part of this dissertation explores the psychological mechanisms on the pathway to stigma. Vulnerability can be modified by childhood trauma. Individuals who have experienced childhood trauma may have a lower self-esteem and be more prone to stereotype awareness. In this mix the experience of stigma occurs more often. In chapter 4 and 5 results of analyses with data of the GROUP (Genetic Risk and Outcome in Psychosis) study are presented. After a description of stereotype awareness and a short presentation of the most important results, I will consider these in a developmental framework of gene-environment interaction and vulnerability and resilience in individuals.

It is generally understood that members of stigmatized groups are devalued and discriminated against by the general public and often suffer from social exclusion and status loss as a result (LeBel, 2008). Since Link's scale (1987) measures individual's recognition of the general public's negative view of the group as a whole (LeBel, 2008), it would be advisable to conduct research using this scale or both of the scales of Struening and colleagues (2001) together with attitude research in the broad society. Stereotypes generally play an integral role in the devaluation of "marked" persons (Biernat \& Dovidio, 2000). Chapter 4 describes the associations between SA and psychological factors - self-esteem and psychopathology - as well as demographic factors - gender, age and ethnicity - and illness duration. In our study, people with more self-esteem were less aware of stereotypes about patients and families. People with more symptoms were more 


\section{Chapter 6}

aware of stereotypes about families, not about patients. We advised that enhancing psychological resources, focusing on self-esteem and the ability to cope with symptoms, may be candidates that can be targeted to diminish stereotype threat and increase stigma resilience. Higher self-esteem may be a protective factor, and coping with symptoms may reduce the consequences of stigma experience. SA may precede or co-occur with self-stigma and can be targeted in conjunction with other aims of treatment.

Chapter 5 reports the degree of SA in patients with psychotic disorder, their siblings and controls. Looking at the associations between childhood trauma and $\mathrm{SA}$, this relationship is stronger in siblings than in patients. We found that certain clusters of symptoms can be related to SA (disorganization and emotional distress). Psychopathology seems to play a role in siblings as well, since schizotypal features, which may indicate vulnerability for psychosis, was associated with SA too.

It is important to consider stigma and (childhood) trauma as environmental factors in gene-environment interaction studies (see chapter 1). Stigma experiences are considered to be modifiable. Although public stigma unfortunately occurs frequently, its effects on daily life as well as on internalization of stereotypes can be modified by coping strategies and resilience building interventions. Although stigma and trauma may have a cumulative defeating effect on the individual over the life course, observations show how people can overcome genetic vulnerabilities and learn to become empowered. Therefore, monitoring stigma experiences can be important, since stigma vulnerability and resilience may vary in time and across contexts.

This dissertation views stigma and childhood trauma from an insider's (or user's) perspective. Although the focus is on individual contributions to stigma resilience it is necessary to combine individual (or group-) focused approaches with interventions applicable on a large scale. Everyone can develop mental health complaints, and everybody can encounter stigma. Therefore awareness campaigns and educating interventions that acknowledge the problem of stigma but also normalize experiences are important. 


\section{An integrative model of stigma experiences}

Gene-environment interactions occur when the effect of exposure to an environmental pathogen on a person's health is conditional on his or her genotype (Caspi \& Moffitt, 2006). If genetic and environmental factors work together to determine outcomes, (e.g. GxE), differences in genetic endowment explain why people respond differently to the same environment (van Os \& Poulton, 2009). People with psychosis spectrum disorder can experience vulnerabilities for perceiving stereotypes and stigma to varying degrees. Vulnerability factors may be all adversities an individual has to cope with such as traumatic experiences in childhood (see chapter 5). A component of resilience is self-esteem (see chapter 4). Other psychological and social factors will also play a role in stigma vulnerability and resilience. Stereotype awareness is an important one. Figure 1 presents a model that includes relevant factors for stigma experience that were studied in this dissertation in a framework of gene-environment interactions, vulnerability and resilience.

One should note that vulnerability and resilience are not fixed traits of the individual. In this dissertation I view vulnerability and resilience as the result of interacting factors that may vary during course of illness (and recovery), life course and circumstances.



Figure 1. Stereotype awareness in an integrative model of gene-environment interactions. 


\section{Chapter 6}

\section{Psychosis vulnerability}

What is it that makes a person vulnerable to develop psychosis? The vulnerabilitystress model proposes that each of us is endowed with a degree of vulnerability that under 'suitable' circumstances will express itself in schizophrenia (Zubin \& Spring, 1977). The original conceptualization by Zubin and Spring regards vulnerability to schizophrenia as a relatively permanent, enduring trait. Nuechterlein and Dawson (1984) presented a modified vulnerability/stress model for schizophrenic episodes. They view certain information-processing deficits, autonomic reactivity anomalies, and social competence and coping limitations as potential vulnerability factors. These are assumed to be modifiable.

\section{Stigma vulnerability}

People encounter innumerous situations, some of which are traumatizing. While childhood trauma (chapter 5) can be an important environmental factor in psychosis spectrum disorder, self-esteem (chapter 4) can be a factor of resilience. Genetic risk for psychopathology, developed vulnerabilities and acquired resilience exert their combined influence (chapter 4 and 5) on SA, rejection sensitivity and belief formation. While SA may lead to self-stigma or internalized stigma, rejection sensitivity may contribute to stigma experiences by the interpretation of situations that may or may not be stigmatizing by themselves (e.g. in anticipated stigma, that is, expecting stigma irrespectively of whether stigma will or will not take place). Moreover, stereotypes may become more salient by both awareness and rejection sensitivity. When an individual becomes more sensitive to rejection, he or she may become more alert or vigilant for stereotypes and perceive these more often. Other types of cognitive bias (e.g. jumping to conclusions and social cognition problems), which may be indicators of stigma vulnerability, may further influence the degree to which stereotypes are perceived to be common in society. Cognitive problems and biases play an important role in the development and continuation of psychosis (van der Gaag et al., 2013) and may play a role in experiencing stigma as well. Also important in the model are life course and context: during the life course people gain knowledge on stereotypes, which may contribute to the degree of salience of these stereotypes later in life. They develop a sense of self-esteem, and may develop symptoms, both of which may vary and contribute to the pathway from stereotype awareness to internalized stigma. 


\section{Awareness of self, stereotypes and one's disorder}

There are more (cognitive) psychological factors that impact on stigma vulnerability. In addition to alertness or cognitive bias, stigma consciousness (Pinel, 1999) or subjective and objective self-awareness (Lewis, 1991) can influence stigma vulnerability and resilience. When attention is directed inward, we focus on ourselves. We are the objects of our own consciousness, what has been called objective self-awareness. When attention is directed away from us, we are the subject of the consciousness that is directed toward external objects, thus the term subjective self-awareness (Lewis, 1991).

Importantly, stigma vulnerability and resilience are also associated with the stages of recovery. People can move from one stage to another in their recovery process, with possible relapse to an earlier phase at one time, and moving quickly through recovery stages later. Therefore, stigma vulnerability and resilience are variable. Although stigma is a barrier to recovery (Perlick, 2001; Wahl, 2012), the more one is aware of the disorder and the more one sees the disorder as an important aspect of one's self, the greater the negative impact of stigma may be. Feldman and Crandall (2007) state: "The critical issue in determining whether individuals will accept or reject people with a particular mental disorder is not whether that disorder is objectively high or low on any of the mental illness dimensions, but the extent to which it is subjectively perceived to be." This may also apply for selfstigma, in which what would matter is how you perceive yourself.

\section{Perceived legitimacy, group value and group identification}

Perceived legitimacy of discrimination shapes reactions to mental illness stigma among stigmatized individuals (Rusch, Todd, Bodenhausen, Olschewski, \& Corrigan, 2010). Automatically activated shame reactions may increase vulnerability to mental illness stigma (Rusch, Todd, Bodenhausen, Olschewski, et al., 2010). Persons with mental illness who associate mental illness with shame may therefore continuously interpret their discrimination as appropriate, because they are consistent with their own cognitive schemata (Rusch, Todd, Bodenhausen, Olschewski, et al., 2010).

Furthermore, if people with mental illness hold their group in high regard (high group value) or reject stigma as unfair (low perceived legitimacy of discrimination), they may be more resilient to stigma (Rusch et al., 2009a). Persons 


\section{Chapter 6}

with intact self-esteem will respond to stigma with indifference or indignation depending on their identification with the generic group of people with mental illness (Corrigan \& Watson, 2002). Furthermore, personality characteristics could be associated with resilience to stigma and the development of internalized stigma may be dependent upon the temperament and character of the patients (Margetic, Jakovljevic, Ivanec, Margetic, \& Tosic, 2010).

\section{Psychosis and resilience}

The concept of resilience has as its starting point the recognition that there is huge heterogeneity in people's responses to all environmental adversities (Rutter, 2012). Resilience is an inference based on evidence that some individuals have a better outcome than others who experienced comparable levels of adversities. Moreover, additional negative experiences may have either a sensitizing effect or a strengthening "steeling" effect in relation to the response to later stress or adversity (Rutter, 2012).

Believing in a merit-based system in which anyone can get ahead on the basis of talent and hard work is a double-edged sword for members of socially devalued groups. It enables them to appraise their world in less threatening ways, but it increases their vulnerability when they encounter evidence that their worldview is false. Rejecting a meritocracy worldview, however, also carries costs as well as benefits. It may lessen the sting when discrimination is encountered, but it may also lead to disengagement from domains in which effort really does pay off or to distrust when trust is warranted (Major, Kaiser, O'Brien, \& McCoy, 2007). 


\section{Destigmatizing interventions}

\section{Interventions aimed at the public}

Corrigan and colleagues (2001) examined the effects of three strategies for changing stigmatizing attitudes -education (or therapy, both of which replace myths about mental illness with accurate conceptions), contact (which challenges public attitudes about mental illness through direct interactions with persons who have these disorders), and protest (which seeks to suppress stigmatizing attitudes about mental illness) - on attributions about schizophrenia and other severe mental illnesses. In a meta-analysis, both education and contact appeared to have positive effects on reducing stigma for adults and adolescents with a mental illness. While contact was better than education at reducing stigma for adults, education was more effective for adolescents (Corrigan, Morris, Michaels, Rafacz, \& Rusch, 2012).

Therapeutic or psycho-educational methods can be applied in (small) groups or individuals. Rosen (Rosen, 2006) gives a summary of what developed countries can learn from developing countries in order to diminish stigma associated with mental disorders. One of the strategies he mentions is to focus more on the individual's role restoration, strengths and abilities and to defocus on its role dysfunction, weaknesses and disabilities. This is an example which can be helpful for both individual's daily life (perception and interpretation of his or her own roles etc.) and for the broad society as well.

In the United Kingdom, a very important anti-stigma initiative is "Time to Change" (www.time-to-change.org.uk). In the Netherlands, "Samen Sterk Tegen Stigma" aims to lessen the taboo on mental illness and end discrimination of people with a psychological vulnerability (www.samensterktegenstigma.nl). Many anti-stigma initiatives have been developed worldwide (www.openthedoors.com). The development of destigmatizing programs in mental illness, can learn from destigmatization in other health conditions and illnesses. These programs should be combined with initiatives to diminish internalized stigma, which are developed more often. 


\section{Chapter 6}

\section{Interventions aimed at the (potential) targets of stigma}

Mittal and colleagues (Mittal, Sullivan, Chekuri, Allee, \& Corrigan, 2012) reviewed the literature about strategies to reduce self-stigma (internalized stigma) among people with mental illness and identified 6 different strategies. Interventions ranged from psycho-education alone to psycho-education combined with cognitive restructuring and more complex or multimodal interventions. Moreover, they identified two contrasting self-stigma reduction approaches: 1) interventions attempting to alter stigmatizing beliefs and attitudes, and 2) interventions encouraging participants to accept the existence of stigmatizing stereotypes without challenging them and enhancing stigma coping skills through improvements in self-esteem, empowerment, and help-seeking behavior (Mittal et al., 2012).

\section{Disclosure}

With respect to destigmatization and daily life for individuals with psychiatric problems, disclosure of one's diagnosis or mental illness is an important issue. People can disclose in different degrees, ranging from social avoidance to broadcasting (educating people about mental illness). Also, one can decide to disclose selectively: with some people private information is disclosed and with some information is kept secret (P. W. Corrigan \& Matthews, 2003; Herman, 1993). It is important to coach people to decide in advance when, what, to whom, and how one wants to disclose. 


\section{Randomized Controlled Trial on increasing stigma resilience: D-STIGMI}

We decided to develop a psycho-educational/ coping skill training to increase the resilience of people suffering from severe mental illness against stigma related threats (externally from the society and internally from the individuals themselves). This became the D-STIGMI (Destigmatizing Mental Illness) program. The central question was "What can you do yourself as a service user to diminish negative consequences of stigmatization?". We wanted to assess its effect in a Randomized Controlled Trial running the experimental condition "psycho-education coping skills

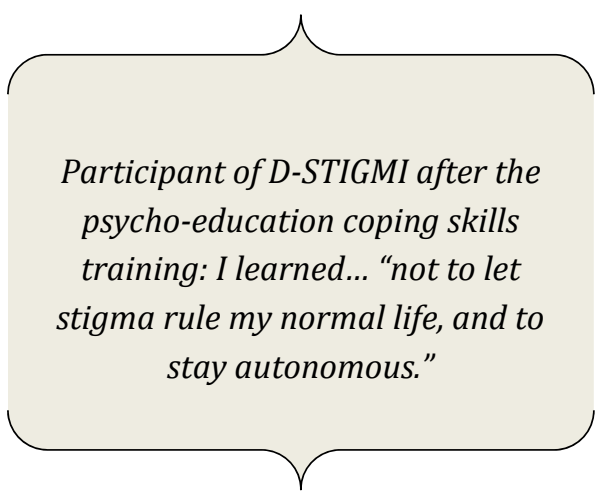
training" - aimed at increasing stigma resilience, against a control condition, a "newspaper reading group". The Experience Sampling Method (ESM) (Csikszentmihalyi \& Larson, 1987; Delespaul, 1995) was used as an outcome method to assess stigma-related experiences in daily life. The ESM holds several advantages over traditional cross-sectional assessment strategies (questionnaires or clinical interviews). It allows reporting temporal relations between variables (what happened and how did you feel before, during and after the event). It has high ecological validity (reports actual emotions in normal situations in situ) and yields detailed information on subjective experiences (Palmier-Claus et al., 2011).

Participants with present or past psychosis or psychotic complaints were recruited using advertisement in care facilities and through local mental health user groups. Subjects were aged 18-65 years, and had sufficient command of Dutch. Subjects were randomized to one of both group programs, consisting each of ten weekly sessions of 1-1.5 hours. Sessions were led by experts by experience and mental health professionals. Baseline measures included an interview, questionnaires, and an optional week of ESM. In the experimental condition subjects received a psycho-education coping skills training (see Appendix A for themes and topics of this training). The participants were provided information, discussed it and shared 


\section{Chapter 6}

personal experiences of stigma, mental illness and treatment. In addition, coping skills were trained (see Appendix B for examples of exercises). The control condition consisted of discussion of news items and exercises surrounding these (for example, answering questions formulated by other participants about newspaper items, or formulating and discussing about statements based upon reading newspaper items that are related to a particular emotion, like anxiety, happiness or sadness). After the 10-week group program, participants were interviewed again and filled in questionnaires. Two months later, a third measurement moment (follow-up) was scheduled with interviews, questionnaires, and (optional) ESM.

Stigma-related experiences can be assessed by studying moment-to-moment mood, psychopathology, social context and activities. It is, however, difficult to relate these fluctuations to stigma related experiences. Asking that repeatedly may create an obsession (and potentially induce stigma). Therefore, stigma-related experiences were measured in the ESM by items, assessed once a day in the evening. The items were: Today I felt rejected, Today I had control over my life, Today I made my own decisions, Today I felt I needed support, Today I could be myself, and Today I felt accepted. These items were rated once each evening on a 7-point Likert scale for 6 days. Furthermore, a cross-sectional questionnaire assessed five stigma coping orientations (B. G. Link, Struening, Neese-todd, Asmussen, \& Phelan, 2002).

To illustrate this with responses of participants, the data of two participants are given below. For each participant, the responses on ESM evening items are shown (baseline and follow-up measurement, see figure $2 \mathrm{a}$ and $3 \mathrm{a}$ ). Answers on the coping orientation questionnaire of Link and colleagues (B. G. Link et al., 2002) are presented as well (baseline, post-treatment and follow-up measurement, see figure $2 b$ and $3 b$ ). 


\section{CASE EXAMPLE 1}

This participant expected at the start of the psycho-education coping skills training that she would gain more insight into stigma and what it entails. The course helped to gain more knowledge on stigma and created awareness of own stigmatizing attitudes, who she beliefs, everyone has. With stigmatizing attitudes she means both public stigma and internalized stigma.

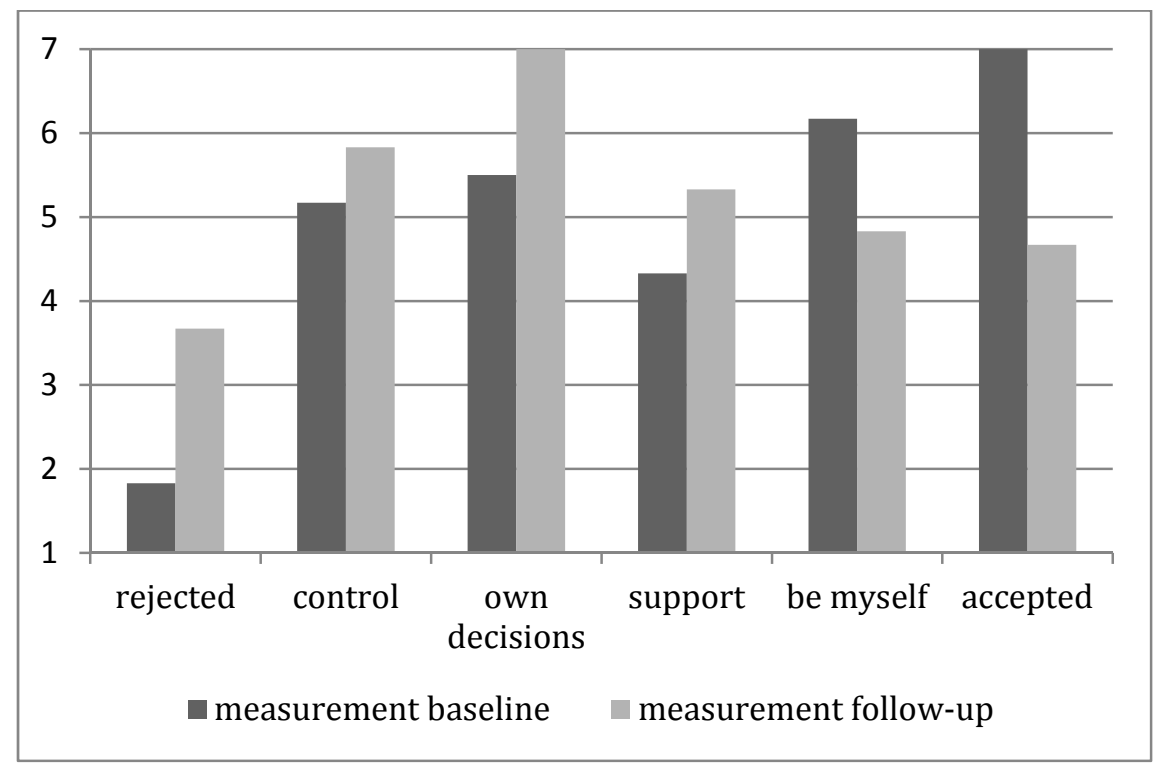

Figure 2a: ESM results on stigma and empowerment for participant $A$

Figure 2a shows how feelings of rejection and need for support increased between baseline and follow-up. Being oneself and feeling accepted decreased. However, the individual got more control over her daily life and made more decisions by herself. On the one hand, stigma awareness seems to have increased, while coping skills related to autonomy and empowerment (control, own decisions) increased as well. It would be valuable to map positive and negative effects of an intervention such as the D-STIGMI program in the short run and in the long run, and take other factors into account in further analyses.

People with mental illnesses are likely to adopt coping approaches designed to avoid or reduce the possibility of rejection. These include keeping one's treatment history a secret, withdrawing from social contacts that might lead to rejection, distancing oneself from the stigma of mental illness by effectively saying "I'm not 
like them," actively challenging stigma when it is encountered, or involving oneself in educational efforts designed to reduce stigma. (Link et al., 2002)

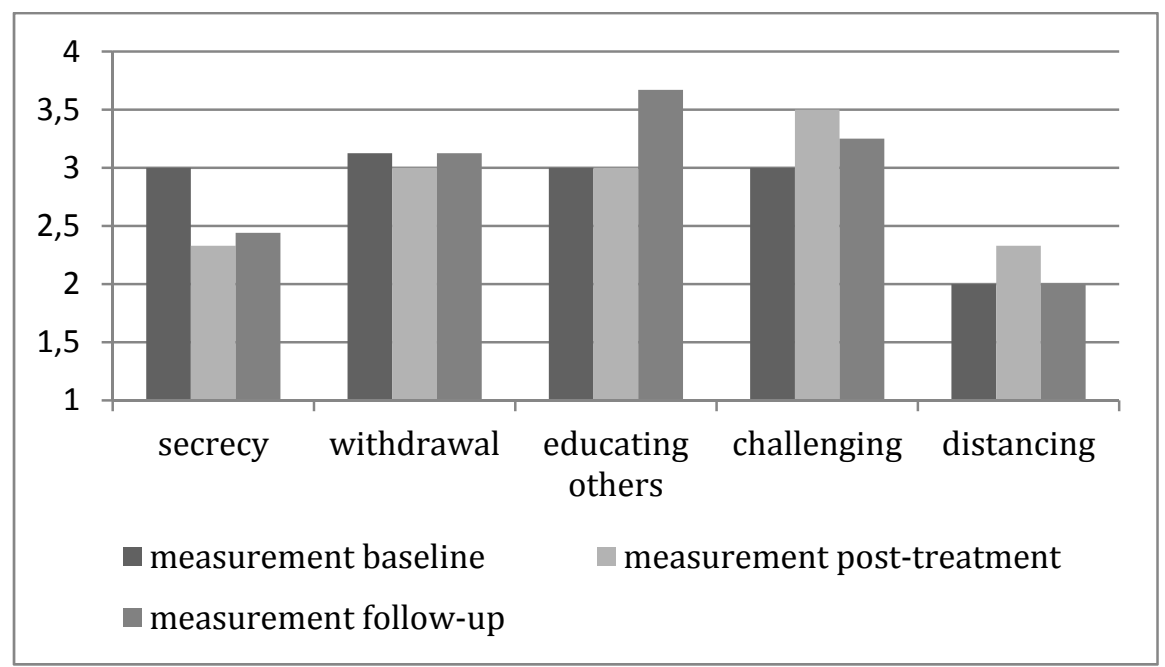

Figure 2b: Coping orientations cross-sectional data of participant $A$

Figure $2 \mathrm{~b}$ shows how post-treatment measurements and follow-up measurements of coping orientations (measured by the stigma coping orientation scales of Link and colleagues (Link et al., 2002)) can differ. The coping orientation of secrecy became less used after the intervention. Educating others had not increased immediately after the intervention but was more often used 2 months after the intervention. While challenging others and distancing became more often used strategies during or immediately after the intervention, they became less often used in the 2 months after the intervention.

\section{CASE EXAMPLE 2}

This participant reported that he had started the course with a positive attitude and found the training informative. Figure 3 a shows how the participant felt rejected at baseline, but not at follow-up. Control, being oneself and feeling accepted increased. The need for support decreased and making own decisions stayed the same. 


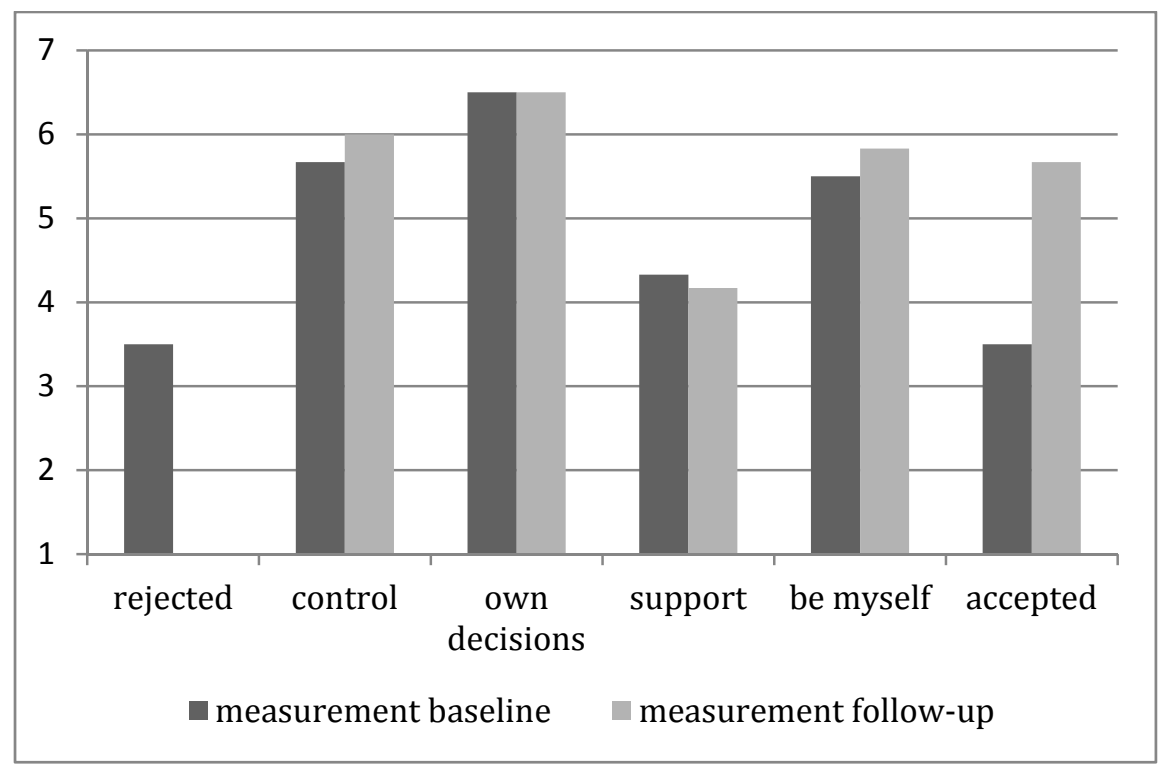

Figure 3a: ESM results on stigma and empowerment for participant $B$

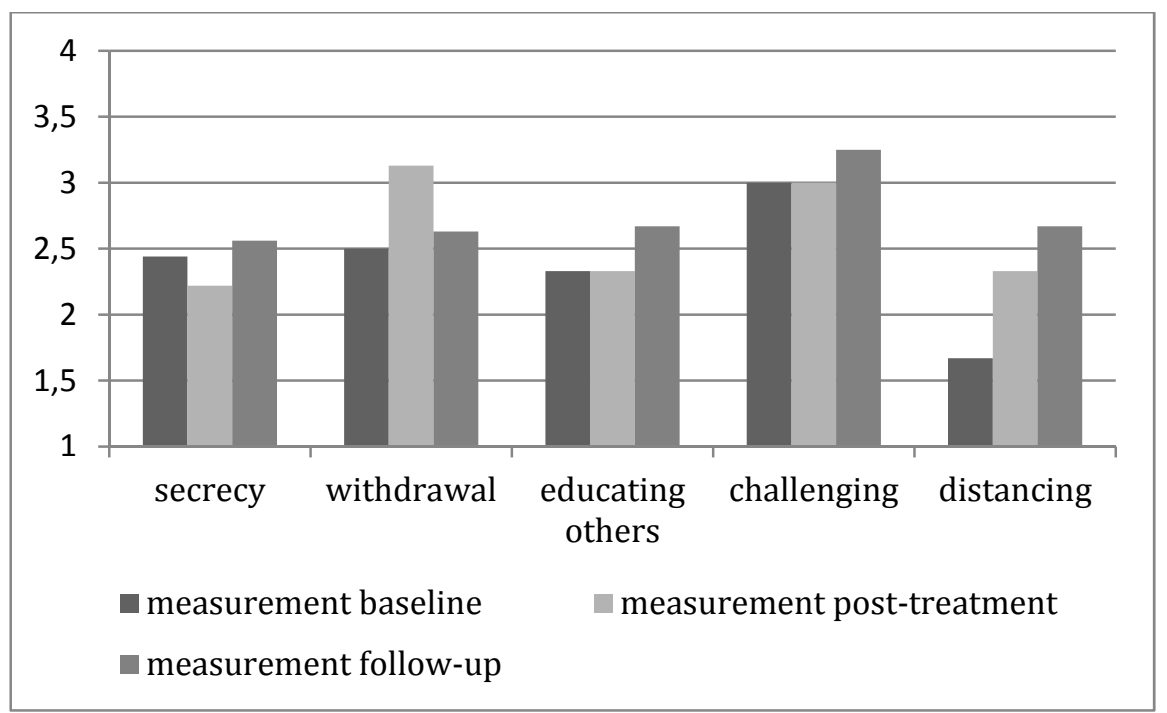

Figure 3b: Coping orientations cross-sectional data of participant $B$

Figure $3 \mathrm{~b}$ shows that the amount of secrecy had decreased at post-treatment measurement and subsequently increased. Withdrawal increased and decreased later. At follow-up, the participant used the coping strategies of educating others, challenging and distancing more often. 
Chapter 6

These results indicate that individual profiling can be useful to assist the person who experiences stigma experiences. It can help to diminish the negative consequences of stigma experiences and point to situations where the individual is more vulnerable or resilient. 


\section{Future}

Many studies assess stigma in relation to mental health and illness. Interventions aimed at reducing internalized stigma are being developed. In this section I will elaborate on some ideas for future research and clinical practice.

\section{Future research}

Experience Sampling can contribute to a better understanding of the interplay between symptoms, personal or social and stigma-related factors in daily life (see results D-STIGMI). Longitudinal research as well as studies using the Experience Sampling Method (Csikszentmihalyi \& Larson, 1987; Delespaul, 1995) can further increase our knowledge on the interplay of the individual with his/her genetic vulnerability and accumulated learning history (as reflected, for instance, in stereotype awareness) and the perceived and interpreted context. Further research into salience and other attentional mechanisms may shed light on attentional differences in people with psychotic disorder, which may partly explain their level of SA at a given time point.

Although stereotype awareness, a component of perceived stigma, is very important in the experiences of many people with mental illness, enacted stigma is of importance as well. Scambler and Hopkins made a distinction between enacted and felt stigma. Enacted stigma refers to instances of discrimination against people on the grounds of their perceived acceptability or inferiority. Felt stigma refers to the fear of enacted stigma, but also encompasses a feeling of shame (Scambler \& Hopkins, 1986).

Future research can also explore the applicability of virtual reality paradigms. Since perceived stigma can be connected to misinterpretation of other people's behavior, virtual reality may prove to be useful in stigma research and interventions (see Freeman, 2008 for a virtual reality paradigm).

Throughout history, mental illness has been interpreted in many different ways, depending on the beliefs of each culture (Gonzalez-Torres, Oraa, Aristegui, Fernandez-Rivas, \& Guimon, 2007). Many ethnic minority communities have a vulnerable status in society because of prejudice and racism, and this is further jeopardized by mental illness (Moodley, 2004). Future research should also incorporate cultural differences. 


\section{Chapter 6}

\section{Future clinical practice}

If a person is viewed solely as a constellation of symptoms and problems, the natural strengths and adaptive capacities of the person are ignored (Coatsworth \& Duncan, 2003). In clinical practice, the individual's capacity to develop resilience should be addressed, and vulnerability acknowledged. Talk-therapy groups based on salutogenic treatment principles improve coping among people with mental health problems (Langeland et al., 2006). Interventions that aim to reduce the impact of stigma on people with mental illness can focus on variables like rejection sensitivity, group value and appraisal of stigma as a stressor (Rusch et al., 2009b).

Peer workers or experts by experience can play an important role in assisting people with psychosis or other mental illnesses to develop more stigma resilience and manage stigma vulnerability.

The development of functional coping should be incorporated in interventions for severe mental illness. Initiatives to reduce internalized stigma among people with mental illness should take worldviews into account (Rusch, Todd, Bodenhausen, \& Corrigan, 2010). Interventions can be developed in participation with service users / experts by experience, who have knowledge about the impact and origins of environmental adversities.

An important element in interventions aimed at diminishing the negative consequences of stereotype awareness or stigma can be increasing stigma resilience and management of stigma vulnerability in individuals. Stereotype awareness is a first component in the process of internalized stigma and therefore necessary to include in destigmatizing interventions in order to increase stigma resilience or empowerment.

When people first experience psychotic symptoms they may or may not seek help, based on for example the distress they experience, access to mental health care, familiarity with these symptoms in their social environment, but also influenced by a phenomenon called label avoidance (see Corrigan \& Wassel, 2008). The stigma against people with mental illness is a major barrier to help-seeking in young people (Rose, Thornicroft, Pinfold, \& Kassam, 2007). When people fear to be labeled or to be associated with mental illness, they may be reluctant to seek help, or to disclose the worsening of symptoms when relapsing after an earlier psychotic episode. Meanwhile, symptoms may exacerbate, which will negatively influence 
the course of the disorder. Awareness of stereotypes or stereotype threat can influence these processes.

According to the Strengths Model, there are four types of strengths: personal qualities/characteristics, skills/talents, environmental strengths, and interests/aspirations (Rapp \& Goscha, 2006, p. 94). The strengths theory posits that a person's quality of life, achievement, and life satisfaction are attributable in large part to the type and quality of niches that a person inhabits (Rapp \& Goscha, 2006, p. 52). Recovery does not mean that a person will no longer experience symptoms. More than having or not having psychiatric symptoms, recovery is about how a person lives his or her life in the midst of experiencing symptoms, facing stigma or trauma, and other setbacks. Recovery means that people stop pathologizing daily life struggles and focus instead on how they can better navigate through life's difficulties to achieve what they desire (Rapp \& Goscha, 2006, p. 15).

In acceptance and commitment therapy (ACT), patients are coached to watch their thoughts mindfully and to feel their feelings fully, rather than trying to change their form, and then to focus on overt actions that will move them in valued directions (Luoma, Kohlenberg, Hayes, Bunting, \& Rye, 2008). ACT is an intervention which remains to be explored in internalized stigma for patients suffering from a psychosis spectrum disorder.

It may well be that while stigma-consciousness renders targets more vulnerable to the negatives of stigmatization, it also gives the motivation needed to set the wheels of change in motion. (Pinel \& Bosson, 2013) Stigma consequences can be reduced by targeting the taboo related to mental illness. Also, and discussing stigma and stigma coping strategies can be valuable for people with these mental health problems. However, focusing on strengths (see Strengths model (Rapp \& Goscha, 2006)), meaning (see Meaning Maintenance Model (Proulx \& Heine, 2006)), and outward or inward focus (see Objective Self-Awareness Theory (Pinel \& Bosson, 2013)) may prove to be more valuable for another group of individuals. Research may further inform us on which intervention will have the optimal effect in improving recovery for the individual. 
Chapter 6

Recommendations for clinical practice

I conclude with some recommendations for clinical practice:

$\diamond$ Ask people with mental illness complaints about stigma experiences.

$\diamond$ Assist the individual in breaking the vicious circle of internalized stigma.

$\diamond$ Identify obstacles for adhering treatment, e.g. label avoidance.

$\diamond$ Contribute to demystifying psychosis by talking about it when all individuals in a conversation are willing to.

$\diamond$ Pay attention to (childhood) trauma.

$\diamond$ Be aware of possible experiences of trauma and stigma in siblings of people with mental illness as well.

$\diamond$ Implement knowledge and skills of experts by experience.

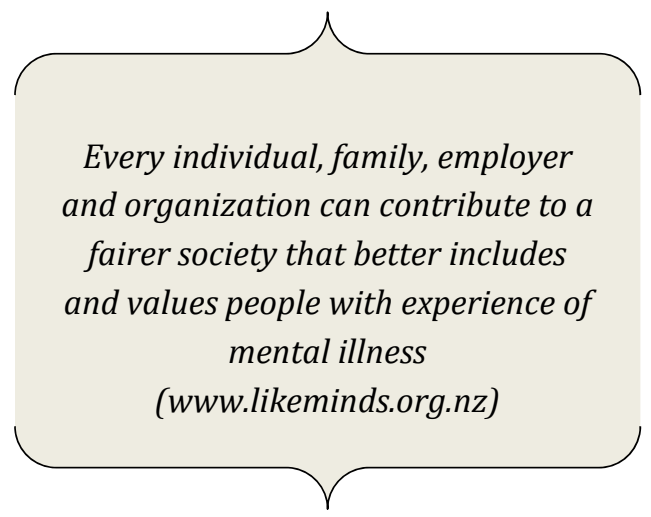




\section{References}

Biernat, M., \& Dovidio, J. F. (2000). Stigma and stereotypes. In T. F. Heatherton, R. E. Kleck, M. R. Hebl \& J. G. Hull (Eds.), The social psychology of stigma (pp. 88125). New York: The Guilford Press.

Caspi, A., \& Moffitt, T. E. (2006). Gene-environment interactions in psychiatry: joining forces with neuroscience. Nat Rev Neurosci, 7(7), 583-590.

Coatsworth, D., \& Duncan, L. (2003). Fostering resilience. A strengths-based approach to mental health.

Corrigan, P. W., \& Kleinlein, P. (2005). The impact of mental illness stigma. In P. W. Corrigan (Ed.), On the stigma of mental illness: Practical strategies for research and social change. Washington, DC: American Psychological Association.

Corrigan, P. W., \& Matthews, A. K. (2003). Stigma and disclosure: Implications for coming out of the closet. Journal of Mental Health, 12(3), 235-248.

Corrigan, P. W., Morris, S. B., Michaels, P. J., Rafacz, J. D., \& Rusch, N. (2012). Challenging the public stigma of mental illness: a meta-analysis of outcome studies. Psychiatr Serv, 63(10), 963-973.

Corrigan, P. W., River, L. P., Lundin, R. K., Penn, D. L., Uphoff-Wasowski, K., Campion, J., Mathisen, J., Gagnon, C., Bergman, M., Goldstein, H., \& Kubiak, M. H. A. (2001). Three strategies for changing attributions about severe mental illness. Schizophr Bull, 27(2), 187-195.

Corrigan, P. W., \& Wassel, A. (2008). Understanding and influencing the stigma of mental illness. J Psychosoc Nurs Ment Health Serv, 46(1), 42-48.

Corrigan, P. W., \& Watson, A. C. (2002). The paradox of self-stigma and mental illness. Clin Psychol Sci Prac, 9, 35-53.

Csikszentmihalyi, M., \& Larson, R. (1987). Validity and reliability of the ExperienceSampling Method. J Nerv Ment Dis, 175(9), 526-536.

Delespaul, P. A. E. G. (1995). Assessing schizophrenia in daily life. The Experience Sampling Method. Maastricht: Universitaire Pers Maastricht.

Feldman, D. B., \& Crandall, C. S. (2007). Dimensions of mental illness stigma: What about mental ilness causes social rejection? Journal of Social and Clinical Psychology, 26(2), 137-154.

Freeman, D. (2008). Studying and treating schizophrenia using virtual reality: a new paradigm. Schizophr Bull, 34(4), 605-610. 
Chapter 6

Gonzalez-Torres, M. A., Oraa, R., Aristegui, M., Fernandez-Rivas, A., \& Guimon, J. (2007). Stigma and discrimination towards people with schizophrenia and their family members. A qualitative study with focus groups. Soc Psychiatry Psychiatr Epidemiol, 42(1), 14-23.

Herman, N. J. (1993). Return to sender: Re-integrative stigma-management strategies of expsychiatric patients. Journal of Contemporary Ethnography, 22(3), 295-330.

Jenkins, J. H., \& Carpenter-Song, E. A. (2008). Stigma despite recovery: strategies for living in the aftermath of psychosis. Med Anthropol Q, 22(4), 381-409.

Jussim, L., Palumbo, P., Chatman, C., Madon, S., \& Smith, A. (2000). Stigma and selffulfilling prophecies. In T. F. Heatherton, R. E. Kleck, M. R. Hebl \& J. G. Hull (Eds.), The Social Psychology of Stigma. New York: The Guilford Press.

Langeland, E., Riise, T., Hanestad, B. R., Nortvedt, M. W., Kristoffersen, K., \& Wahl, A. K. (2006). The effect of salutogenic treatment principles on coping with mental health problems A randomised controlled trial. Patient Educ Couns, 62(2), 212219.

Langeland, E., Wahl, A. K., Kristoffersen, K., \& Hanestad, B. R. (2007). Promoting coping: salutogenesis among people with mental health problems. Issues Ment Health Nurs, 28(3), 275-295.

Lazarus, R. S., \& Folkman, S. (1984). Stress, appraisal, and coping. New York: Springer Publishing Company, Inc.

LeBel, T. P. (2008). Perceptions of and Responses to Stigma. Sociology Compass, 2(2), 409-432.

Lewis, M. (1991). Ways of knowing: Objective self-awareness or consciousness.

Developmental Review, 11, 231-243.

Link, B. G. (1987). Understanding Labeling Effects in the Area of Mental Disorders: An Assessment of the Effects of Expectations of Rejection. American Sociological Review, 52, 96-112.

Link, B. G., Struening, E. L., Neese-todd, S., Asmussen, S., \& Phelan, J. C. (2002). On describing and seeking to change the experience of stigma. Psychiatric Rehabiliation Skills, 6(2), 201-231.

Luoma, J. B., Kohlenberg, B. S., Hayes, S. C., Bunting, K., \& Rye, A. K. (2008). Reducing self-stigma in substance abuse through acceptance and commitment therapy: Model, manual development, and pilot outcomes. Addiction Research and Theory, 16(2), 149-165.

Major, B., Kaiser, C. R., O'Brien, L. T., \& McCoy, S. K. (2007). Perceived discrimination as worldview threat or worldview confirmation: implications for self-esteem. $J$ Pers Soc Psychol, 92(6), 1068-1086. 
Margetic, B. A., Jakovljevic, M., Ivanec, D., Margetic, B., \& Tosic, G. (2010). Relations of internalized stigma with temperament and character in patients with schizophrenia. Compr Psychiatry, 51(6), 603-606.

Mittal, D., Sullivan, G., Chekuri, L., Allee, E., \& Corrigan, P. W. (2012). Empirical Studies of Self-Stigma Reduction Strategies: A Critical Review of the Literature. Psychiatr Serv, 63(10), 974-981.

Moodley, P. (2004). Ethnicity: Relationship to stigmatisation of people with mental illness. In A. H. Crisp (Ed.), Every Family in the Land: Understanding prejudice and discrimination against people with mental illness. London: Royal Society of Medicine Press Ltd.

Nuechterlein, K. H., \& Dawson, M. E. (1984). A heuristic vulnerability/stress model of schizophrenic episodes. Schizophr Bull, 10(2), 300-312.

Palmier-Claus, J. E., Myin-Germeys, I., Barkus, E., Bentley, L., Udachina, A., Delespaul, P. A., Lewis, S. W., \& Dunn, G. (2011). Experience sampling research in individuals with mental illness: reflections and guidance. Acta Psychiatr Scand, 123(1), 12-20.

Perlick, D. A. (2001). Special section on stigma as a barrier to recovery: Introduction. Psychiatr Serv, 52(12), 1613-1614.

Pinel, E. C. (1999). Stigma consciousness: the psychological legacy of social stereotypes. $J$ Pers Soc Psychol, 76(1), 114-128.

Pinel, E. C., \& Bosson, J. K. (2013). Turning our attention to stigma: An objective selfawareness analysis of stigma and its consequences. Basic and Applied Social Psychology, 35, 55-63.

Proulx, T., \& Heine, S. J. (2006). Death and Black Diamonds: Meaning, Mortality, and the Meaning Maintenance Model. Psychological Inquiry, 17(4), 309-318.

Rapp, C. A., \& Goscha, R. J. (2006). The Strengths Model. Case Management with People with Psychiatric Disabilities. (Second ed.). New York: Oxford University Press.

Rose, D., Thornicroft, G., Pinfold, V., \& Kassam, A. (2007). 250 labels used to stigmatise people with mental illness. BMC health services research, 7, 97.

Rosen, A. (2006). Destigmatizing day-to-day practices: what developed countries can learn from developing countries. World Psychiatry, 5(1), 21-24.

Rusch, N., Corrigan, P. W., Wassel, A., Michaels, P., Olschewski, M., Wilkniss, S., \& Batia, K. (2009a). Ingroup perception and responses to stigma among persons with mental illness. Acta Psychiatr Scand, 120(4), 320-328.

Rusch, N., Corrigan, P. W., Wassel, A., Michaels, P., Olschewski, M., Wilkniss, S., \& Batia, K. (2009b). A stress-coping model of mental illness stigma: I. Predictors of cognitive stress appraisal. Schizophr Res, 110(1-3), 59-64. 
Chapter 6

Rusch, N., Todd, A. R., Bodenhausen, G. V., \& Corrigan, P. W. (2010). Do people with mental illness deserve what they get? Links between meritocratic worldviews and implicit versus explicit stigma. Eur Arch Psychiatry Clin Neurosci, 260(8), 617625.

Rusch, N., Todd, A. R., Bodenhausen, G. V., Olschewski, M., \& Corrigan, P. W. (2010). Automatically activated shame reactions and perceived legitimacy of discrimination: A longitudinal study among people with mental illness. J Behav Ther Exp Psychiatry, 41(1), 60-63.

Rutter, M. (2012). Resilience as a dynamic concept. Dev Psychopathol, 24(2), 335-344.

Scambler, G., \& Hopkins, A. (1986). Being epileptic: coming to terms with stigma. Sociology of Health and Illness, 8(1), 26-43.

Struening, E. L., Perlick, D. A., Link, B. G., Hellman, F., Herman, D., \& Sirey, J. A. (2001). Stigma as a barrier to recovery: The extent to which caregivers believe most people devalue consumers and their families. Psychiatr Serv, 52(12), 16331638.

van der Gaag, M., Schutz, C., Ten Napel, A., Landa, Y., Delespaul, P., Bak, M., Tschacher, W., \& de Hert, M. (2013). Development of the Davos assessment of cognitive biases scale (DACOBS). Schizophr Res, 144(1-3), 63-71.

van Os, J., \& Poulton, R. (2009). Environmental vulnerability and genetic-environmental interactions. In H. J. Jackson \& P. D. McGorry (Eds.), The recognition and management of early psychosis. A preventive approach. (2nd ed.). New York: Cambridge University Press.

van Zelst, C. (2009). Stigmatization as an environmental risk in schizophrenia: a user perspective. Schizophr Bull, 35(2), 293-296.

Wahl, O. F. (2012). Stigma as a barrier to recovery from mental illness. Trends Cogn Sci, 16(1), 9-10.

Zubin, J., \& Spring, B. (1977). Vulnerability--a new view of schizophrenia. J Abnorm Psychol, 86(2), 103-126. 


\section{APPENDIX A: Psycho-education coping skills training D-STIGMI}

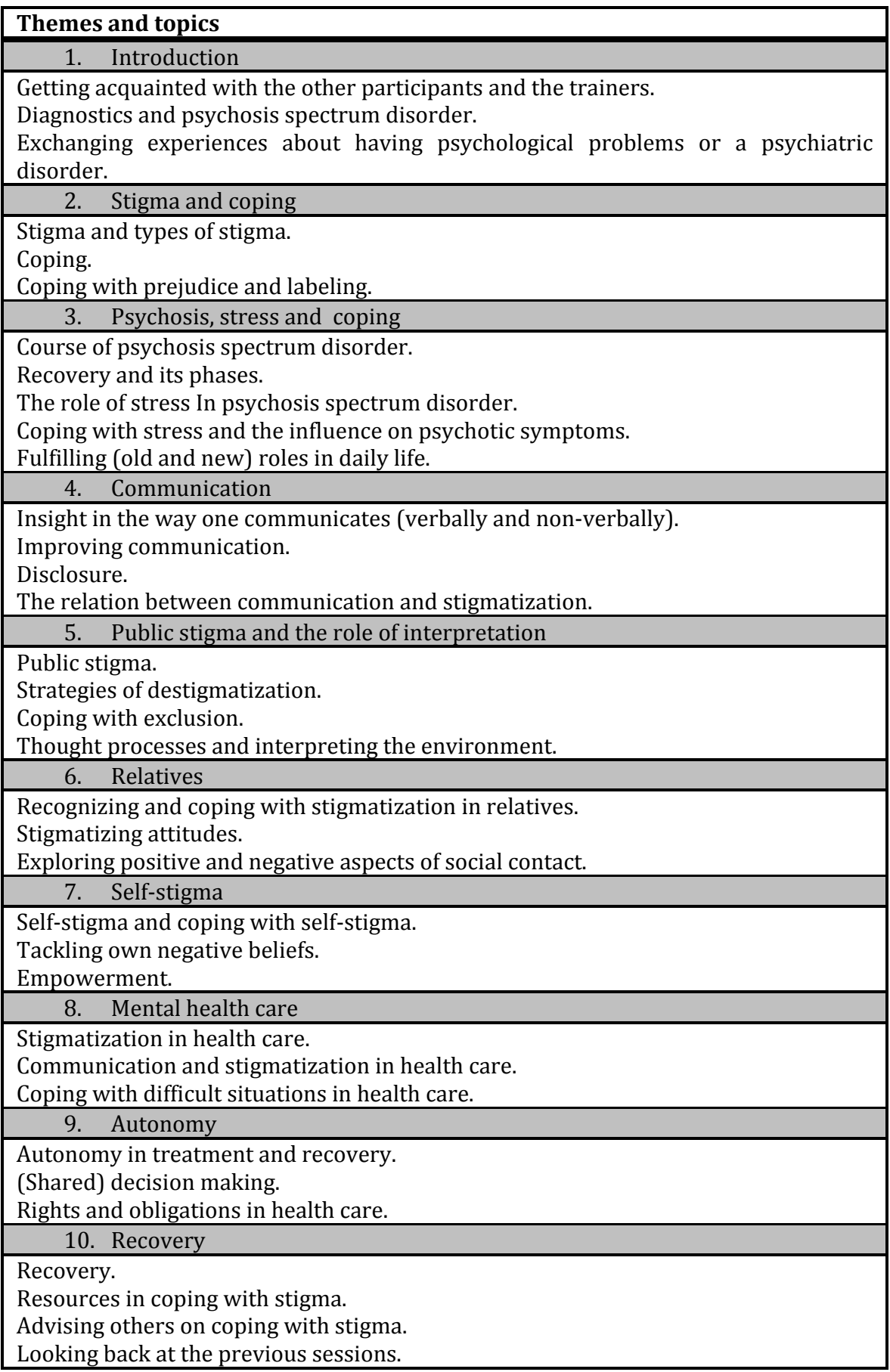

Table 1: Themes and main topics psycho-education coping skills training 


\section{APPENDIX B: Examples of exercises in the psycho-education coping skills training}

Important elements of the sessions were group discussion and exercises (aimed to increase stigma resilience). Two examples of exercises are the following:

1. Group discussion: Experiences with having a mental disorder (exercise from the first session)

"In this group discussion you can talk with the other participants about your experiences with having a mental disorder. What does having a mental disorder mean to you? Which consequences did it have?"

This exercise was meant to give people the opportunity to share their own experiences as well as to get familiar with each other's experiences. Examples given by subjects were the experiences of..

$\diamond$ someone close to you labelling an emotion as a symptom, and as a warning sign that things might become worse

$\diamond$ being viewed and treated in a negative way by people in your own village

$\diamond$ not being allowed by other people to talk about the voices you hear

$\diamond$ medication use and side-effects

$\diamond$ addiction

During the sessions participants could talk about anything (no taboo). Trauma before and after psychosis were also addressed, while in some participants experiences of trauma appeared to be related to public stigma and subsequently internalized stigma. Participants listened to each other, asked each other questions and gave advice based on their own experience. One of the two trainers shared his own experiences and this helped participants to talk more freely about their own experiences.

\section{Exercise and group discussion: Thoughts on the way to today's session (exercise from session 7 on internalized stigma)}

"In this exercise you consider step by step your thoughts when you were on your way to this session. Write down as many of your thoughts as possible while you were on your way. It is about everything you thought, both thoughts you think are important as well as thoughts you think are unimportant. In this session we talk about these thoughts." 
$\diamond$ "What would other people think when I buy this?"

$\diamond$ Thoughts about stigma while reading about the training on the way to the training.

$\diamond$ Stop one's own thinking

$\diamond$ "Did I do something wrong?"

$\diamond$ "People are looking at me."

This exercise was meant to identify possible thoughts that could be indicative of internalized stigma, and subsequently search for strategies the individual can deal with these thoughts. While some reported thoughts were thoughts of paranoia, they were sometimes related to public as well as internalized stigma. Some participants became more aware of their own internalized stigma during the course, and actively tried to break the vicious circle of internalized stigma and its negative effects on self-esteem and hope. 



\section{Samenvatting}

Stigmatisering en jeugdtrauma zijn twee belangrijke omgevingsfactoren die een rol kunnen spelen bij de wederzijdse beïnvloeding van genen en omgevingsfactoren (gen-omgevingsinteracties) bij mensen met een psychose-spectrum-stoornis. Ik licht dit toe in deel 1 van dit proefschrift. In deel 2 vervolg ik met een beschrijving van resultaten van het GROUP-onderzoek (Genetic Risk and Outcome of Psychosis). In dit onderzoek is het bewustzijn voor stereotypen, stereotype awareness, onderzocht. Dit deden we bij mensen met een psychose-spectrumstoornis, hun broers en zussen en controlepersonen. Uit analyses bleek dat gevoel van eigenwaarde, jeugdtrauma en psychopathologie factoren zijn die kunnen samenhangen met stereotype awareness. Hoofdstuk 4 rapporteert de resultaten over gevoel van eigenwaarde en stereotype awareness bij patiënten. Hoofdstuk 5 rapporteert naast een vergelijking tussen patiënten, broers en zussen, en controlepersonen, ook de resultaten van patiënten respectievelijk broers en zussen van patiënten apart. Hierbij wordt gekeken naar de samenhang met symptomen (bij patiënten) en kenmerken van schizotypie (bij broers en zussen).

DEEL 1 van het proefschrift geeft een samenvatting van wetenschappelijke bevindingen over stigma en jeugdtrauma als etiologische omgevingsfactoren voor het ontwikkelen van een psychose.

Hoofdstuk 1: Welke omgevingsfactoren bij gen-omgevingsinteracties? Een cliëntperspectief op de rol van trauma en structurele discriminatie bij het begin en verloop van schizofrenie. Dit hoofdstuk benadrukt het belang van trauma en stigma (onder andere structurele discriminatie) als factoren bij gen-omgevingsinteracties bij psychose-spectrum-stoornis. Het haalt bewijs aan voor trauma tijdens jeugd of volwassenheid als een risico voor individuen die kwetsbaar zijn voor het ontwikkelen van een psychose. Trauma beïnvloedt individuen mogelijk niet alleen voor een eerste psychotische episode. Psychotische ervaringen zelf en de gevolgen van behandeling en afwijzing door de maatschappij kunnen ook traumatizerend zijn (hertraumatizering). In het hoofdstuk wordt onderscheid gemaakt tussen verschillende vormen van stigma en de mogelijke gevolgen. Stigma kan invloed hebben op het verloop en mogelijk ook op het begin van een psychose-spectrumstoornis. Voorbeelden van mechanismen via welke stigma deze kan beïnvloeden 
worden toegelicht. Hoewel niet iedereen met een psychische aandoening trauma of stigma heeft ervaren, kunnen deze factoren begin, verloop en uitkomst bij een subgroep van mensen met psychotische ervaringen beïnvloeden. Ze zijn daarom een belangrijk aandachtspunt bij coping (omgaan met stress). Stigma en de negatieve gevolgen kunnen beschouwd worden als stressoren. Terwijl individuen hun eigen copingstrategieën ontwikkelen en kunnen leren van lotgenoten, kunnen mensen binnen of buiten de geestelijke gezondheidszorg hen helpen bij het omgaan met trauma en stigma waar nodig.

Hoofdstuk 2: Stigma als een omgevingsrisicofactor bij schizofrenie: een cliëntperspectief. Dit hoofdstuk beschouwt stigma als een veranderbare omgevingsfactor die zijn invloed uitoefent via verschillende wegen. Dit proces kan na diagnose van een stoornis plaatsvinden, maar ook daarvoor. Het theoretische model dat gepresenteerd wordt geeft verschillende momenten aan waarop stigmatisering zijn invloed kan uitoefenen. Wanneer gedrag als afwijkend of deviant wordt waargenomen, kan stigmatisering plaatsvinden.

Hoofdstuk 3: Trauma en stigma als ervaringen gedurende de levensloop en interacteren met genetische factoren bij schizofrenie. In hoofdstuk 3 beschouw ik trauma en stigma als omgevingsfactoren die cumulatieve gevolgen kunnen hebben die het individu negatief kunnen beïnvloeden ('defeat') gedurende de levensloop en in samenspel met genetische kwetsbaarheid het begin en de uitkomst van psychotische symptomen kunnen beïnvloeden. Interventies die zich richten op voorlichting en op "salutogene" aspecten (wat maakt een mens gezond of helpt hem of haar te herstellen?) kunnen nuttig zijn bij het doorbreken van de vicieuze cirkel die met jeugdtrauma of stigma-ervaringen kan beginnen.

DEEL 2 van dit proefschrift verkent psychologische mechanismen bij stigmaervaringen. Kwetsbaarheid kan beïnvloed worden door jeugdtrauma. Individuen die jeugdtrauma hebben ervaren kunnen een lager gevoel van eigenwaarde hebben en gevoeliger zijn voor het bewust zijn van stereotypen. Hoofdstuk 4 en 5 rapporteren resultaten van het GROUP onderzoek.

Hoofdstuk 4: Bewustzijn voor stereotypen, gevoel van eigenwaarde en psychopathologie bij mensen met psychose. Dit hoofdstuk beschrijft de associaties tussen bewust zijn van stereotypen, psychologische factoren (gevoel van eigenwaarde en psychopathologie), demografische factoren (geslacht, leeftijd en 
ethniciteit) en ziekteduur. In het onderzoek waren mensen met een hoger gevoel van eigenwaarde zich minder bewust van stereotypen over patiënten en hun families. Mensen met meer symptomen waren zich meer bewust van stereotypen over families, maar niet over patiënten. We gaven aan dat het versterken van psychologische bronnen, met aandacht voor gevoel van eigenwaarde en het vermogen om met symptomen om te gaan, aanknopingspunten kunnen zijn voor het verminderen van dreiging van stereotypen en het verhogen van veerkracht op het gebied van stigmatisering. Bewust zijn van stereotypen kan voorafgaan aan of samengaan met zelfstigma. Dit kan samen met andere doelen van behandeling aangepakt worden.

Hoofdstuk 5: Associaties tussen bewustzijn voor stereotypen, jeugdtrauma en psychopathologie: Een onderzoek bij mensen met psychose, hun broers en zussen, en controlepersonen. Dit hoofdstuk rapporteert de mate waarin patiënten met een psychose-spectrum-stoornis, hun broers en zussen en controlepersonen zich bewust zijn van stereotypen. De associatie tussen jeugdtrauma en bewust zijn van stereotypen is sterker bij broers en zussen dan bij patiënten. We vonden dat bepaalde groepen van symptomen kunnen samenhangen met het bewust zijn van stereotypen. Psychopathologie lijkt ook een rol te spelen bij broers en zussen, aangezien kenmerken van schizotypie, die kunnen wijzen op kwetsbaarheid voor het ontwikkelen van een psychose, ook met het het bewust zijn van stereotypen samenhing.

Hoofdstuk 6: Algemene discussie. In de discussie wordt het bewust zijn van stereotypen geplaatst in een theoretisch model van gen-omgevingsinteracties die via kwetsbaarheid en veerkracht, en samen met een gevoeligheid voor afwijzing, kunnen leiden tot dysfunctionele en functionele overtuigingen over iemand zelf en anderen. Na een toelichting van dit model, bespreek ik interventies die kunnen helpen bij het verminderen van stigmatisering. Hierbij komen zowel interventies gericht op de maatschappij, als interventies gericht op het individu aan de orde. Ook openheid over psychische aandoeningen komt aan bod. Vervolgens wordt het D-STIGMI onderzoek (Destigmatizing Mental Illness) beschreven, waarin een psycho-educatie copingvaardigheidstraining gericht op het verhogen van weerbaarheid tegen stigma wordt geëvalueerd. Het maken van individuele profielen van stigma-gerelateerde ervaringen in het dagelijks leven, hier met behulp van de Experience Sampling Method, kan behulpzaam zijn bij het inzicht 
krijgen in stigma-ervaringen, het hiermee om leren gaan of het een ander hierbij helpen. Het laatste onderdeel van de discussie bestaat uit suggesties voor verder onderzoek op het gebied van stigma en voor destigmatiserende interventies.

Aanbevelingen voor de klinische praktijk zijn:

$\diamond$ Vraag mensen met klachten van een psychische aandoening naar stigmaervaringen.

$\diamond$ Begeleid het individu bij het doorbreken van de vicieuze cirkel van geïnternaliseerd stigma.

$\diamond$ Identificeer hindernissen voor therapietrouw, bijvoorbeeld etiketvermijding.

$\diamond$ Draag bij aan het demystificeren van psychose door erover te praten wanneer alle individuen in een gesprek daartoe bereid zijn.

$\diamond$ Geef aandacht aan (jeugd-)trauma.

$\diamond$ Wees ook bewust van mogelijke ervaringen van trauma en stigma bij broers of zussen van mensen met een psychische aandoening.

$\diamond$ Implementeer kennis en vaardigheden van ervaringsdeskundigen. 


\section{Valorization}

Stigma is a severe problem for many people with psychosis. Both public stigma (the negative expectations and reactions of society to an individual or group) and self-stigma / internalized stigma (the negative expectations and reactions of the individual to the self) hamper recovery. This dissertation describes stigma as an environmental risk factor for onset, course and outcome of psychosis (chapter 1, 2 and 3). It presents results on stereotype awareness (chapter 4 and 5), the perception of generalized beliefs in society.

Stereotype awareness can reflect public stigma and is a first component of the process in which people internalize stereotypes and consequently experience. We studied stereotype awareness and self-esteem, psychopathology, and childhood trauma - factors that constitute resilience (the ability to adapt and cope successfully despite threatening or challenging situations) and vulnerability for stigma experiences. The study shows how stereotype awareness is associated with selfesteem (more self-esteem = less stereotype awareness) and childhood trauma (more childhood trauma $=$ more stereotype awareness) in people with psychosis. Although the presented studies are cross-sectional, a better understanding of stigma contributes to the optimized care for people with psychosis. First of all, we studied stereotype awareness in relation to childhood trauma. This possible relationship has rarely been studied before. Furthermore, in our study, stereotype awareness was not only studied in people with psychosis, but also in their siblings and in controls. Stereotype awareness was associated to childhood trauma (more childhood trauma $=$ more stereotype awareness) in patients and in siblings. Their awareness of stereotypes was not restricted to patients with mental illness, but also included relatives.

\section{Relevance}

\section{Scientific relevance}

Increased knowledge about stigma and its components and occurrence can inform interventions to reduce the detrimental effect of stigmatization. 


\section{Social relevance}

Mental illness creates a huge burden and tops the lists of illnesses with the highest social (and economic) impact. (Severe) mental illnesses carry a burden on their own, but stigma makes it worse. Diminishing stigma and its consequences, by integrating results into new treatment and education programs, can improve reintegration of people with psychosis or psychotic experiences and reduce its related burden in society.

\section{Economic relevance}

Mental health care costs increased dramatically over the previous years. Reducing burden will also reduce costs. Further research can point out how much costs can reduce by destigmatization programs related to mental health care and lost productivity.

\section{Target groups}

The research results can be of interest to the academic community, patients with severe mental illness, their relatives, (mental) health care professionals including experts by experience, students of psychological and/or medical studies, employers and policy makers.

\section{Academic community}

Although the amount of research into stigma in severe mental illness is increasing, stereotype awareness in the three groups studied (patients, siblings and controls) considering both stereotypes with respect to patients as well as relatives is exploring extra concepts (i.e. mental illness stigma in siblings and controls; stereotype awareness with respect to families of people with mental health problems). This study adds to the research on stereotype awareness. Further research may inform us on stereotype awareness in mental illnesses other than psychosis.

\section{Patients}

For patients with psychosis, the results can point out that coping with stigma and stereotype awareness specifically is important. Coping with stigma has proved to 
be possible. Merely doing the research points out that stigma is important for people with mental illness and opens the way to debate on this societal phenomenon. Results of the studies into self-esteem, psychopathology and childhood trauma can be integrated in new psycho-education and therapeutic interventions as well as in (other) work of experts by experience. Psychosis and trauma are both still taboo to a degree, and this makes finding ways to make these issues topics in interventions is important. For example, people can be assisted to become (more) stigma resilient.

\section{Relatives}

The results are relevant for relatives of people with psychosis as well. Siblings can partly share a degree of stereotype awareness with their relatives with psychosis. Childhood trauma and schizotypal features can play a role in this process. Siblings may be vulnerable for stigma experiences as well, for example by associative stigma or affiliate stigma (the extent of self-stigma among associates of targets of stigma). Stigma in families should be further explored.

\section{Society at large}

Members of the society were included as controls in this study. They did not differ much in the degree to which they were aware of stereotypes. This can point to the fact that stereotype awareness is a general phenomenon. However, stereotype awareness may impact differently on patients, siblings and controls.

\section{Mental health care}

(Mental) health professionals should be informed about stigma theory and practice as well. Previous research has shown that internalized or self-stigma occurs in about $30 \%$ of people with severe mental illness. Moreover, a part of stigma experiences take place in (mental) health care settings, e.g. the stigmatizing effects of treatment itself (iatrogenic stigma). Experts by experience who work in (mental) health care settings can implement (theoretical and practical) knowledge in their work with patients suffering from psychosis as well. 


\section{Students}

When students in the field of psychology or medicine are already informed of stigma and stereotype awareness, they may get sensitized to recognize stigma in their future profession. It is important to be aware of own stigmatizing attitudes as well as of the possibility of getting stigmatized reactions as well when working as a mental health care professional.

\section{Workplace}

Since research has shown that, although many employers think underestimate the degree of mental health problems among their employees, probably every employer will encounter mental health problems among their employees. Therefore, they should also be informed about stigma, stereotypes and its consequences. People may perform better when there is a possibility to talk about mental health problems and stigma when needed.

\section{Policy makers}

Finally, destigmatization should be or become a point on the agenda of policy makers. Since one in four people get a mental illness, mental health problems should not be overlooked or neglected.

\section{Activities/products}

This dissertation also includes some results of a study into stigma resilience: D-STIGMI / Destigmatizing Mental Illness. This study evaluated a new psychoeducation coping skills training aimed to increase stigma resilience. This training developed for people with severe mental illness and schizophrenia/psychosis in particular, can be adjusted with results of the stereotype awareness studies. We will further implement the psycho-education coping skills training in mental health care, and present new results on conferences on psychiatry and psychology.

Moreover, lectures about stigma and psychiatry are given by the author to students of the Faculty of Health, Medicine and Life Sciences (FHML) and the University College of Maastricht University. 


\section{Innovation}

The psycho-education coping skills training is innovative in how it was developed. Patients, relatives and mental health professionals have contributed in workgroups to the formulation of concepts, needs for new psycho-education material and by sharing their own experience with mental illness and stigma. Moreover, the training combines psycho-education with coping skills training. The trainers can be (and have been during the D-STIGMI study) experts by experience/mental health professionals. Experts by experience can make it easier to talk about painful experiences that psychosis and stigma can be for participants of the training. Finally, the D-STIGMI study is a user-led study.

\section{Schedule and implementation}

Several mental health institutions/facilities have expressed interest in enrolling the training. We will update the training, making it suitable for people other than people with psychosis, and continue with implementation of the training the following years. 



\section{Dankwoord}

Binnen en buiten de afdeling Psychiatrie en Psychologie van de Universiteit Maastricht heb ik de afgelopen jaren velen mogen ontmoeten die mij gemotiveerd en geïnspireerd hebben en ieder op hun eigen manier de weg naar voltooiing van dit proefschrift, en soms een (nog) groter deel van mijn leven, beïnvloed hebben.

Mijn grote dank gaat uit naar mijn promotoren, Prof. Dr. Philippe Delespaul en Prof. Dr. Jim van Os.

Philippe en Jim, dankzij jullie steun en het vertrouwen dat jullie in mijn leggen heb ik talrijke onbekende situaties aan durven gaan.

Philippe, voor uw begeleiding en vertrouwen, voor de inspirerende gesprekken en voor uw engelengeduld ben ik intens dankbaar. Dat u mij ook nog na de $80^{\mathrm{e}}$ keer wiskunde probeert te laten begrijpen is bewonderenswaardig. Fijn dat uw deur altijd open staat.

Jim, heel blij was ik toen ik, ondanks dat ik zei dat ik psychotisch was geweest, de kans kreeg om te gaan werken op je afdeling. Nog blijer was ik toen ik met mijn eigen onderzoeksvoorstel een promotieonderzoek mocht gaan uitvoeren. Met je snelle to the point antwoorden heb je me goed weten te begeleiden.

Niet alleen ben ik tijdens mijn promotie bijgestaan door bovengenoemde promotoren. Ook mijn andere collega's maakten het werk soms lichter, vaak plezieriger, en altijd interessanter.

Maarten, tof dat je ook na onze samenwerking voor NEMESIS bent blijven rondhangen en altijd geïnteresseerd bent. Door je relativerende humor ga ik, als je m'n werkplek weer verlaat, altijd met een frisse blik weer verder. Heerlijk, met name wanneer vastroesten (achter m'n bureau of in een theoretisch model) op de loer ligt. Ik denk dat het met of zonder big whopper wel goed komt. 
Zonder deelnemers geen onderzoek, en ook geen onderzoeksmotivatie. Ik dank alle deelnemers van D-STIGMI voor de inzet tijdens het onderzoek. Ook hoe zij zich open hebben gesteld tijdens de groepsprogramma's vond ik niet alleen bijzonder, maar waardeer ik erg.

Achter de schermen werd er veel werk verzet om het D-STIGMI onderzoek mogelijk te maken. Ik dank allen die hebben bijgedragen aan het ontwikkelen van de groepsprogramma's, alle trainers van deze programma's, de onderzoekscoördinatoren, interviewers, data-invoerders en last but not least de secretariële en computerondersteuning.

Peter, het contact met jou heb ik vanaf dag één heel bijzonder gevonden. Je bent een voorbeeld voor me voor hoe je ervaringsdeskundigheid in kunt zetten, en een goede collega en vriend. Als jij er bent, ben je er echt. Fijn dat je de rol van paranimf wilt vervullen.

Martine, bedankt voor de gezellige intermezzo's en dat ook jij tijdens mijn verdediging als paranimf aan mijn zijde wilt staan. Je onderzoek vormt een bron van inspiratie.

Yorgo, de klik was er wat mij betreft al tijdens het begeleiden van de psychoeducatiegroep. Ik hoop weer met je samen te mogen werken in de toekomst. Bedankt voor de gezellige en inspirerende autoritten.

Dank aan alle promovendi en andere onderzoeksmedewerkers die ik in de afgelopen jaren op onze afdeling heb leren kennen, sommigen nog steeds in beeld, anderen alweer verder in hun leven en carrière.

Allen die hier niet genoemd staan, maar toch regelmatig in mijn gedachten voorbij vliegen, bedankt voor de inspiratie, leuke momenten en stof tot nadenken.

Graham Thornicroft and Diana Rose, I thank you very much for a great, inspiring month at the Institute of Psychiatry, in particular the Service User Research Enterprise, in London. 
Cher, thank you for your fantastic music and lyrics; they make travelling for work a lot more pleasant every day.

Pa en ma, bedankt voor het meegeven van doorzettingsvermogen, en van de liefde voor muziek die me plezier en afleiding brengt en een uitlaatklep wanneer nodig.

Heit en Mem, vanaf het eerste moment heb ik me thuis gevoeld. Bedankt voor het stimuleren, zowel door steun als door opbouwende kritiek met een knipoog.

Gevleugelde vrienden, kleine viervoetertjes en zwemmend gevaar. Niet alleen brengen jullie een hoop plezier. Jullie zijn prachtig.

Nienke van Dijk, Geliefde. Reddende engel. Zonder jou was dit alles niet mogelijk geweest. Bedankt voor je werk aan de ontwikkeling van de psycho-educatie. En voor de gesprekken die ervoor zorgden dat mijn verhaal woorden kreeg, waardoor dit proefschrift deze introductie heeft.

Immens dankbaar ben ik dat je op zo'n bijzondere manier deel uit maakt van mijn leven. Ik bewonder je om je inzichten, je schrijven, je humor, je menselijkheid,.. en kan me geen heerlijker mens voorstellen om mee samen te mogen leven. 



\section{Curriculum Vitae}

Catherine van Zelst werd geboren op 31 december 1979 te Oirschot. Na haar VWO- opleiding aan het Jacob Roelandslyceum te Boxtel, begon zij in 1998 aan de studie Gezondheidswetenschappen aan de Universiteit Maastricht. In 2006 studeerde zij af in de specialisaties Geestelijke Gezondheidkunde en Gezondheidsvoorlichting. In 2007 startte zij bij de vakgroep Psychiatrie en Psychologie van de Universiteit Maastricht als onderzoeksassistent. Bij dezelfde vakgroep werd zij in 2009 aangesteld als promovenda. Daar deed zij onderzoek naar weerbaarheid tegen stigmatisering bij mensen met ernstige psychiatrische aandoeningen (D-STIGMI / Destigmatizing Mental Illness). 



\section{List of Publications}

Journal articles

van Nierop, M., Viechtbauer, W., Gunther, N., van Zelst, C., de Graaf, R., Ten Have, M., van Dorsselaer, S., Bak, M., GROUP, \& van Winkel, R. (2014). Childhood trauma is associated with a specific admixture of affective, anxiety, and psychosis symptoms cutting across traditional diagnostic boundaries. Psychol Med, 1-12.

van Nierop, M., Lataster, T., Smeets, F., Gunther, N., van Zelst, C., de Graaf, R., ten Have, M., van Dorsselaer, S. Bak, M., Myin-Germeys, I., Viechtbauer, W., van Os, J., \& van Winkel, R. (2014). Psychopathological mechanisms linking childhood traumatic experiences to risk of psychotic symptoms: analysis of a large, representative population-based sample. Schizophr Bull, 40 Suppl 2, S123-130.

van Nierop, M., van Os, J., Gunther, N., van Zelst, C., de Graaf, R., ten Have, M., van Dorsselaer, S., Bak, M., Myin-Germeys, I., \& van Winkel, R. (2014). Does social defeat mediate the association between childhood trauma and psychosis? Evidence from the NEMESIS-2 Study. Acta Psychiatr Scand, 129(6), 467-476.

van Zelst, C., van Nierop, M., Oorschot, M., Myin-Germeys, I., van Os, J., Delespaul, P., \& Group. (2014). Stereotype awareness, self-esteem and psychopathology in people with psychosis. PLoS One, 9(2), e88586.

van Zelst, C. (2010). Trauma and stigma as defeating experiences over the life course interacting with genetic liability in schizophrenia. European Psychiatric Review, 3(1), 35-38.

van Zelst, C. (2009). Stigma and schizophrenia. Lancet, 373(9672), 1336; author reply 1336-1337.

van Zelst, C. (2009). Stigmatization as an environmental risk in schizophrenia: a user perspective. Schizophr Bull, 35(2), 293-296.

van Zelst, C. (2008). Which environments for G x E? A user perspective on the roles of trauma and structural discrimination in the onset and course of schizophrenia. Schizophr Bull, 34(6), 1106-1110. 


\section{Submitted article}

van Zelst, C., van Nierop, M., van Dam, D. S., Bartels-Velthuis, A. A., Delespaul, P., \& GROUP-investigators. Associations between stereotype awareness, childhood trauma and psychopathology: A study in people with psychosis, their siblings and controls. 